\title{
SĂPĂTURI DE SALVARE LA HANUL CONSTANTIN VODĂ (1996)
}

\author{
Eugen S. TEODOR, Anca PĂUNESCU, \\ Emest OBERLÄNDER-TÂRNOVEANU, \\ Mihai TOMESCU
}

\section{RESCUE DIGGINGS AT CONSTANTINE VODĂ INN, BUCHAREST (1996)}

A major real estate development required a rescue archaeology intervention in the very downtown Bucharest, mainly between February and June 1996. A large section, 75 long and about $3 \mathrm{~m}$ large was made in the street, mostly mechanically, just in the front of the National History Museum.

The archaeological rescue digging documented 12 rooms belonging to a large inn, built by a famous Ruler of the Romanian Country (Tara Românească), Constantin Brâncoveanu, in the last decade of the XVII ${ }^{\text {th }}$ century. This kind of inn, of Oriental inspiration, is typical for the passage from Late Middle Age to Modern times, and is, in fact, a complex project including hosting areas, enclosure for animals, large storehouses, but usually churches also. Flourishing in towns with a certain demographic growth, but with a very poor communication means, like Bucharest, the inns were supposed to gather all goods needed by community in five months of cold and wet weather, when the road network was impracticable.

The inn functioned about 160 years, until around 1860, the internal spaces being frequently restored, up to 7 times. Despite the fact that the landlord was unique, for its entire existence, a comparison between the type of internal rehabilitation operations proved that the initiative was left on tenants, the sequence type of floors (wood, bricks or vegetal cover) being unrepeatable. The use of the spaces - when proved by micromorphological study - is also distinctive, either cooking area, workshops connected with open fire, or even stables for sheep, for some relatively short episodes. Those 12 rooms are placed on the westem wing of the building, on the main facade, facing a major street - Podul Mogoşoaiei - studied in the southern end of the archaeological section. The public road was made of wooden boards supported by wooden pillars buried under the walking level, similarly with a bridge, from which the street took its name ("pod" meaning bridge). This type of public street, made entirely of wood, is documented in wet lowlands, where stone is not available, like Timişoara (westem Romania).

The history of the place begins during the late $\mathrm{XV}^{\text {th }}$ century, for which deep buried huts were discovered. For the mid XVI ${ }^{\text {th }}$ century a new type of house was in use, made of wood, relatively large and with cellars, typical for aristocracy. In the XVII ${ }^{\text {th }}$ century this strip of land was no more a constructive area, a little cemetery being discovered in the southern part of the trench. The layers dated between the cellar-houses and the inn are first in which fragments of bricks and mortar were recorded, probably from buildings in proximity.

Regarding the political history of the Romanian countries, it might be surprising that from our discoveries Ottoman coins are missing. We found instead some Turkish pipes, a good witness of adopting an oriental life-style.

This paper also presents the main results of the sedimentological and micromorphological study performed on Constantin Vodă Inn archaeological site. The field study firstly considered in the analysis of the sedimentary successions observed on the main stratigraphic profiles and the identification of the different types of units. The main diagnostic criteria observed in the field at the macroscopic level texture, structure, color, nature of constituents, homogeneity and degree of compaction - allowed establishing a typology of sedimentary facies necessary for the interpretation in terms of mechanisms of formation, in order to identify human activities and post-abandon transformations of the accumulated deposits. Thus, different types of construction and arrangement units, occupation units and natural accumulations were recognized. Micromorphological analysis, at the microscopic scale, brings detailed information on the sedimentary units and thus contributes to a better interpretation of the archaeological levels. Extraordinary information provided by this study is the identification of sferulites, structures indicating the presence of the domestic animals (Ovis/Capra) in spaces fitted out with a wooden floor. The palinological expertise - the first ever done in an archaeological site from Bucharest - revealed a predominance of a ruderal vegetation, followed by hydrophilic vegetation and lowlands trees, but not cereals, explained by the position is in the middle of the medieval town.

KEYWORDS: Late Middle Age, rescue digging, inn, pottery, interdisciplinary research CUVINTE CHEIE: Ev mediu târziu, arheologie de salvare, han, ceramică, cercetare interdisciplinară 


\section{INTRODUCERE}

În iarna 1995-1996, pe terenul viran dintre Palatul CEC şi clădirea magazinului Victoria se săpase o groapă mare, ce anunța o clădire impunătoare, cu mai multe niveluri în subteran şi foarte multe niveluri deasupra. Era ceea ce avea să se numească atunci Turnul Bancorex, iar după falimentul răsunător al băncii -Financial Plazza. În ianuarie a apărut un şanţ lat de 3 metri, la limita trotuarului cu Calea Victoriei, din dreptul Muzeului Naţional de Istorie a României şi până la interseç̧ia cu strada Lipscani. Am aflat astfel că se făceau lucrări de aducţiune de apă pentru noua investitie. Şanţul de aducţiune era plin de ziduri de cărămidă, dar nimeni nu părea să știe exact ce ar trebui făcut pentru ca investitorul să-şi tempereze graba; normal - câtă vreme, la acel moment, nu exista încă legislaţia de protecţie a patrimoniului (ziceam noi). Datorăm Inspectoratului General al Poliţiei, aflat în proximitate, oprirea barbariei, prin "mijloace specifice". Așa au ajuns arheologii în stradă, să-şi facă meseria. Segmentul din faţa Bisericii Zlătari, între străzile Stavropoleos şi Lipscani, a fost luat de Muzeul Municipiului Bucureşti, respectiv de Gh. MănucuAdameşteanu, iar segmentul din faţa Muzeului Naţional —de angajaţii acestei instituftii, cum era normal, în ciuda statutului nostru „,ateritorial”, fără legături ombilicale cu Primăria Capitalei şi factorii decidenţi ai municipiului.

Echipa din teren a MNIR a fost condusă de Eugen S. Teodor, asistat de Silviu Oţa, Mihaela Simion şi Dana Mihai, toţi arheologi debutanţi, la momentul respectiv. Am primit ajutor, în diverse momente, mai ales pentru discutarea unor aspecte stratigrafice sau pentru realizarea unor desene, de la colectivul Centrului Naţional de Cercetări Pluridisciplinare al MNIR, mai ales de la Constatin Haită, sedimentologul nostru; neîndoielnic, săpătura de salvare în oraş aduce probleme stratigrafice cu care arareori un arheolog se poate întâlni într-o săpătură „sistematică”, departe de zgomotul maşinilor. Desfaş̧urându-se la vedere, sub treptele Muzeului, a fost o săpătură ,deschisă”, precum o sală de operaţie sub un clopot de sticlă, fiind asistaţi şi consiliał̧i de mulţi alţi colegi, precum Anca Păunescu conducătorul Secţiei de Istorie și Arheologie Medievală, Dragomir N. Popovici îndrumătorul CNCP, sau Paul Damian, şeful, pe atunci, al unui minuscul „Birou de Arheologie Preventivă", înaintaş al numeroasei Secţii de astăzi. Diverse contribuţii au avut şi alţi angajaţi ai MNIR, restauratorii, de pildă, sau alł̧i colegi din secţiile de specialitate.

Lucrările din stradă s-au desfăşurat, cu intensitate, între jumătatea lunii februarie și luna iunie, cu scurte reveniri în toamnă, prilejuite de noi intervenţii ale constructorului, în zona trotuarului din fata clădirii MNIR, şi în primăvara următoare, cu mici cercetări în subsolul MNIR, în vechiul depozit de arheologie medievală, unde au fost sesizate fundații mai vechi. Raportul, în forma publicată acum, a fost finalizat la sfârşitul anului 1996 şi a rămas, în linii generale, nepublicat. Există totuşi câteva excepții. Osteologii, mai conectaţi ritmurilor occidentale decât arheologii, şi-au publicat rezultatele într-o revistă străină (Bălăşescu et alii 2002). În anul 2005, fosta noastră colegă, Dana Mihai, a publicat în Cercetări Arheologice în București un studiu în care își expune propriul punct de vedere. În elaborarea acelei lucrări domnia a folosit, neautorizat, desene care nu-i aparţineau, inventând şi un colectiv plin de "doctori" (nici unul dintre cei enumeraţi acolo nu era doctor, în anul 1996), cu adausuri şi lipsuri în listă greu de înţeles. Singura sa contribuţie la elaborarea raportului din anul 1996 a fost aducerea de la Arhivă a unei copii după planul de detaliu al lui Borroczyn, din martie 1848, referitor la Hanul Constantin Vodă. Desenul publicat de Dana Mihai nu-i aparţine, ci, aşa cum greu s-ar ghici între cuvintele piezişe, saturate de licenţe prozaice _, ,prelucrarea a fost realizată de dr. arhg. Silviu Teodor" (Mihai 2005, 273, nota 9)aparţine conducătorului şantierului, care l-a „lucrat”, nu „prelucrat”, de la ridicarea topografică la transpunerea ei digitală, şi de la digitizarea planului Borroczyn la suprapunerea cu planul săpăturilor arheologice. În acelaşi raport iniţial, Dana Mihai avea două scurte secţiuni, respectiv a 
doua (Documente scrise şi topografice despre Hanul Constatin Vodă) şi a patra (Elemente ale sistemului constructiv). Fiindcă domnia sa şi-a exprimat deja punctul de vedere, într-o manieră personală de care arheologii MNIR se despart, secţiunea a doua, de documentare istorică, a fost complet refăcută cu acest prilej, iar secţiunea a patra a fost desfiinţată, fiindcă amplul raport stratigrafic (secţiunea 3) cuprinde suficiente elemente descriptive ale sistemului constructiv.

Celelalte secţiuni ale raportului din anul 1996 au fost păstrate în forma iniţială, cu câteva corecturi, precum adaptarea sistemului de note la standardele de azi. A fost păstrată în linii mari chiar şi structura ilustraţiei, deşi a existat tentaţia modificării ei radicale, fiindcă după 15 ani lucrurile se văd cu siguranţă altfel. A fost schimbat doar suportul grafic al planşei III, doar pentru claritatea superioară (Radu Oltean în loc de George Potra), fiind adăugate planşele III/2 şi III/3, rezultat al studiilor mai recente. De asemenea, intervenţiile recente în text au fost plasate ca note de subsol, trimiterile la bibliografia post 1996 fiind un indiciu în acest sens, cu excepţia secţiunii a doua a raportului, care este scrisă în anul 2011.

Impulsul publicării acestui raport, după atâta vreme, a fost dat de ceea ce se întâmplă în stradă, sub ochii noştri, prilejuit de lucrările de reabilitare a Centrului Istoric. Mărturisim perplexitatea noastră în constatarea că s-a putut găsi atunci, în anul 1996, mai multă înţelegere şi cooperare din partea instituţiilor statului, dar finalmente şi din partea antreprenorilor privaţi, deşi încă nu existau legi de protecţie a patrimoniului, decât acum, când ele există. Afirmăm încă o dată, explicit şi răspicat, că arheologii nu sunt inamicii progresului, că nimeni nu-şi imaginează că poate îngheţa imaginea orașului, la nici un moment istoric, şi că avem convingerea că o bună colaborare între planificatori, executanţi, instituţiile abilitate cu protecţia patrimoniului şi instituţiile cu expertiză arheologică şi istorică, ar putea produce rezultate demne de o capitală europeană, fără întârzieri majore în execuţia investiţiilor şi fără distrugerea haotică a patrimoniului; ceea ce nu este cazul, deocamdată...

Ne-am hotărât deci să ne scuturăm de praf vechile planuri, să recuperăm -cu greutate - desene realizate în softuri care nu se mai folosesc de tare multă vreme (precum CorelDraw2!), pentru ca recentele cercetări de salvare din jurul Muzeului Naţional de Istorie să-şi găsească suportul planimetric şi stratigrafic, pentru a putea fructifica puţina cercetare care s-a putut face în anii din urmă.

Materialul este structurat pe secţiuni, urmând acestei introduceri, astfel: 2 . Istoricul locului pe care s-a construit Hanul Constantin Vodă (Eugen S. Teodor); 3. Descrierea săpăturii de salvare. Planimetrie şi stratigrafie (Eugen S. Teodor); 4. Ceramica (Anca Păunescu); 5. Catalogul monedelor şi a altor artefacte databile intrinsec (Emest Oberländer-Târnoveanu); $6 . \quad$ Studiul sedimentologic (Constantin Haită); 7. Studiul palinologic (Mihai Tomescu).

\section{ISTORICUL LOCULUI PE CARE S-A CONSTRUIT HANUL CONSTANTIN VODĂ}

Eugen S. TEODOR

Despre subiectul adus aici, în introducerea cercetărilor arheologice din anul 1996, există câteva lucrări la care cititorul poate face apel: o ediţie mai veche a istoriei hanurilor bucureștene, semnată de George Potra în 1943 (Hanurile Bucureştene), unde se pot găsi informaţii utile, dar mai degrabă sumare (p. 14-16); o ediţie mai nouă, cu informaţie mult îmbogăţită (Potra 1985, 5565); în fine, articolul publicat de Dana Mihai (2005), evocat şi în prezentarea introductivă a raportului. Aceste rânduri sunt destinate doar a scuti cititorul grăbit de a căuta aceste surse, de a înţelege mai uşor conţinutul acestui raport, fără ajutor bibliografic suplimentar, de a pune, finalmente, obiectul nostru de studiu într-un cadru istoric cât de cât definit.

Hanurile au apărut în Bucureşti atât ca urmare a unei mode central şi est-europene, cât şi a unor necesităţi uşor de explicat, în cursul veacului al XVII-lea. De veche inspiraţie genoveză, dar implementat, ca program arhitectonic şi urbanistic, sub influenţă otomană ${ }^{1}$, hanul era, deopotrivă, un

\footnotetext{
${ }^{1}$ Consideratiile noastre de atunci au fost confirmate mult mai târziu, de o foarte interesantă teză de doctorat susţinută la Universitatea de Arhitectură şi Urbanism „Ion Mincu” de Petru Mortu (Arhitectura cu specific
} 
loc de popas, un antrepozit de mărfuri din cele mai diverse, un loc de găzduire, având în aceleaşi timp certe valenţe comerciale, cu zeci de magazine diferite, fiind şi un loc fortificat, care punea la adăpost vieţi şi bunuri, în vremuri tulburi (cum a fost, de exemplu, Revolutia de la 1821). Adesea, în interiorul hanurilor existau şi locuri de închinăciune şi reculegere, de regulă ele fiind în administrarea unor mănăstiri. $\mathrm{Nu}$ este completamente cazul Hanului Constantin Vodă, care a fost administrat cea mai mare parte a istoriei sale de egumenul mănăstirii Văcărești, dar pentru care nu există 0 mărturie clară că ar fi avut biserică² .

Explicaţia pragmatică a apariţiei hanurilor este legată de creşterea demografică a oraşelor de la finalul evului mediu. Datorită căilor de comunicaţie nemodernizate, în care transportul cu carele cu boi era sever limitat de noroaiele anotimpului rece, populaţia tot mai numeroasă a oraşelor făcea necesară existenţa unor spaţii mari de depozitare a produselor diverse, de la cele necesare gurii la mărfuri de import pentru nevoile protipendadei, în cantităţi suficiente pentru cele patru-cinci luni de izolare hibernală. Stocarea atâtor mărfuri de valoare justifica şi nevoia unor construcţii solide, dând cel puţin iluzia unui loc întărit; hanurile aveau, la origine, un plan patrulater, cu o singură intrare, blocată cu uşi masive de stejar şi ferecături, pentru a garanta vieţile şi proprietăţile, cel puţin în faţa răufăcătorilor. Aspectul lor iniţial de incintă fortificată avea să fie modificat tot de nevoi practice: sporirea concurenţei comerciale va obliga prăvăliașii să se deschidă spre stradă, pentru a face vitrine atractive, după moda occidentală, care să le aducă mai multă clientelă. Lupta celor două modele este ilustrată de contrastul dintre

comercial. Hanurile), la 9 decembrie 2011, sub îndrumarea prof. Anca Brătuleanu.

${ }^{2}$ În ciuda opiniei exprimate tranşant de Dana Mihai (2005, 271). De altfel, Hanul Constantin Vodă este enumerat explicit între cele şapte hanuri bucureștene fără biserică, în surse de epocă (Potra 1985, 61). Faptul nu exclude existenta unei capele, dar pozitia ei nu poate fi precizată (clădirea care figurează în curte?). Despre un paraclis al Hanului Constantin Vodă vorbeşte şi George Florescu (1935, XIV), într-o enumerare a monumentelor „care s-au dus” (exprimarea lui), dar cu greu această evocare ar putea fi un argument probatoriu, părând mai degrabă o presupunere firească. planul hanului, cunoscut în detaliu pentru mijlocul veacului al XIX-lea (PI. II-IV), şi planul realizat prin săpătură arheologică, ce dezvăluie mai degrabă strategia iniţială. Despre aceste lucruri însă - în secţiunea următoare a raportului.

Atunci când Vodă Brâncoveanu venea la conducerea Tării Românești, la 1688, în Bucureşti exista deja un han celebru, realizat de înaintaşul său pe tron, Şerban Vodă, aflat acolo unde astăzi se ridică Banca Naţională a României. Succesul comercial al acestei iniţiative „capitaliste", dar şi faima de care hanul se bucura, ducând dincolo de moarte numele întemeietorului său, avea să stimuleze noul domnitor să dorească să imite -şi dacă se poate chiar să depăşească- ctitoria precursorului. Problema adevărată era să găsească Vodă un teren destul de mare, în Târgul Dinăuntru —adică oraşul propriu-zis, numit astăzi „centrul istoric”- care era deja ocupat de diverşi proprietari; evident, ar fi fost de dorit ca locul să fie şi cât mai aproape de Curtea Domnească şi de reședinţa Brâncovenilor, aflată pe celălalt mal al Dâmboviţei, în zona Pieţii Unirii de astăzi. Ocazia s-a ivit curând. Constantin Brâncoveanu a ajuns la domnie cu sprijin otoman, împotriva facţiunii boierești care dorea continuarea politicii lui Şerban Vodă, de apropiere de Austria. Armata habsburgică trimisă împotriva noului domnitor a fost bătută de turci la Zărneşti, în anul 1790, iar pretendentul adus de ei, Constantin Bălăceanu, a fost ucis pe câmpul de luptă. Bălăcenii deţineau un teren mare în târgul Bucureștilor, cuprins între viitoarea uliță Stavropoleos, la nord, viitorul „Pod al Mogoşoaiei”, la vest, şi podul lui Șerban Vodă (adică strada podită care dădea la han, ulterior ulița Nemţească, astăzi strada Smârdan) la est, limita de sud fiind mai puţin clară (dar probabil strada Franceză) ${ }^{3}$. Evident, pământul

\footnotetext{
3 Această limită de sud a fost problematică pe toată durata de functionare a hanului. Potra (1943, 14-15) mentionează că, după unele surse (Florescu 1932, 43), proprietăţile cu ieşire la ulită aparțineau familiei Ştirbey, care cumpăraseră acele terenuri la 1782. O sugestie similară este oferită şi de cele mai vechi planuri ale Bucureştilor, datorate ofiţerilor austrieci Ernst și Purcel (cca. 1791), planuri lipsite însă de detalii; planul încă și mai vechi, datorat lui Sulzer (1781; prezentat şi de Potra 1985, pe prima planşă după p. 64) prezintă doar trama stradală, nefiind de ajutor. Nu cunoaştem deci configuraţia clădirilor, sau structura
} 
trădătorului a fost confiscat, începând neîntârziat construcţia hanului, undeva la vest de biserica Sf. Dumitru-Poştă (paraclis al Bălăcenilor, de lemn la momentul acela).

Dupã execuţia lui Constantin Brâncoveanu şi a familiei sale, la 1714, multe dintre proprietăţile sale sunt înstrăinate, dacă nu pur şi simplu confiscate, ipoteză mai plauzibilă. Din anul 1716 începe construcţia Mănăstirii Văcărești de către domnitorul Nicolae Mavrocordat, moment după care hanul ajunge în administrarea sfântului lăcaş, contribuind la întreţinerea acestuia prin chiriile plătite, rămânând aceluiaşi beneficiar pentru restul duratei sale de funcţionare, până cel puţin în deceniul şase al veacului al XIXlea. Clădirea, ca întreg cartierul, sunt afectate în mod repetat de diverse năpaste, precum incendiul din 1719 (Panait 1973, 64 apud Mihai 2005, 272), ciuma din 1792, sau cutremurele din 1802 şi 1838 (Tico 1979, 399).

Ştirile despre han se înmulţesc în perioada finală, care urmează Revoluţiei de la 1821. Aflăm astfel că, speriaţi de evenimentele din stradă, mușteriii hanului se refugiază la Braşov, unde se aflau încă la 1824, uitând să-și plătească chiria, iar egumenul mănăstirii îi dã în judecată pentru recuperarea prejudiciului. Motivul invocat era că clădirea se află în stare proastă şi are nevoie de reparaţii, care nu s-au putut însă face datorită rău-platnicilor (Potra 1985, 5960). Chiriaşii au fost obligaţi a plăti jumătate din datoria lor, însă reparaţii nu s-au făcut. Cutremurele succesive, urmate de ,focul mare" de la 1847 , au afectat definitiv trăinicia clădirilor. O parte din han (nu se spune care, dar vom vedea că este cea sudică) este dărâmat chiar de călugări, înainte de 19 decembrie 1849. Chiar şi aşa, hanul pare

de proprietate, în primul secol de existenţă a hanului. Documentul din anul 1793, citat de Potra (1943, 15) amintește proprietarii învecinaţi, pe toate laturile, însă lista nu clarifică deloc aspectele cadastrale. $\mathrm{Cu}$ puţină vreme înaintea „focului mare” care avea să distrugă hanul, la 1847 , negustorul Mihai Baier aducea marfă din Viena, atrăgându-şi clienţi cu următoarele: „Doritorii de a avea lucru bun şi modem să îndreptează la prăvălia sa ce este în Uliţa Franţozească, împotrivă [vis-à-vis] de poarta Hanului Constantin Vodă" (Fotino, Istoria Daciei, vol. III, 166, apud Potra 1943, 15), ceea ce înseamnă că accesul în han s-a păstrat, pe acea parte, până la sfârşit. părăsit de cei mai mulţi dintre clienţii obişnuiţi, câtă vreme incinta capătă în câteva rânduri întrebuinţări militare; astfel, în mai 1849 s-a dat ordinul de dezarmare a locuitorilor capitalei, prin confiscarea armelor folosite în revoluţie, armele vechi fiind stocate, apoi distruse, în incinta hanului; la puţină vreme apoi aici se instala garnizoana Regimentului 2 infanterie (Potra 1985, 60). Printre periculoasele ruine ale fostului han mai existau însă proprietari şi chiriaşi, care se opun din răsputeri planurilor primăriei de a curăţa locul; presa vremii este plină de reclamaţii ale vecinilor, de memorii disperate ale proprietarilor ameninţaţi cu demolarea, de comisii de specialitate ale municipalităţii, destinate a diagnostica starea bolnavului.

În concluziile comisiei din iunie 1853 se spunea că clădirile dinspre Uliţa Franţuzească, precum şi o parte din corpul dinspre Podul Mogoşoaiei, erau din paiantă, ca şi casa din mijlocul curţii (era deci „casă”, nu ,paraclis" sau altceva), ,în proastă şi primejdioasă stare şi prin urmare trebuiesc dărâmate fără întârziere"; despre celelalte corpuri, respectiv cel dinspre uliţa Stavropoleos şi parte din cel spre Podul Mogoşoaiei (deci partea nordică a faţadei), se afirma că sunt suficient de solide, dar că necesită reparaţii; comisia mai recomanda ca „bolţile etajului de sus să se desfiinţeze" (Potra 1985, 62-63). George Potra credea că toate acestea au rămas „filă de dosar”, adică încă un document fără consecinţe. Se pare că cel puţin o parte a recomandărilor acestei comisii din anul 1853 au devenit faptă, pentru că planul Jung, datat 1856 , prezintă clădirea în formă de $\mathrm{L}$, respectiv laturile de nord şi vest $^{4}$, deci partea de sud a hanului, făcută (mai exact refăcută) din paiantă, fuseseră dărâmate.

Reclamaţiile şi memoriile în jurul demolărilor ţin presa bucureşteană încă câţiva ani. Lent dar sigur, o parte a clădirilor sunt demolate, fiindcă în mai 1861 apare, în

\footnotetext{
${ }^{4}$ După mărturia Danei Mihai, care probabil a avut acces la material. Oricum, este greu de înţeles finalul frazei domniei sale: „În planul Jung din 1856 apare figurat hanul în mod diferit fată de cel al lui Borroczyn. Interesant de observat este faptul că hanul pare să fie în formă de $L$, respectiv pe laturile de nord şi vest, iar restul clădirilor având să fie adăugate ulterior" (? Mihai 2005, 273).
} 
Buletinul Municipiului București, un anunł conform căruia, pe locul unde fuseseră altădată frumoasele case ale Bălăcenilor, dărâmate de Brâncoveanu din răzbunare, ca să facă han în locul lor, urma a se deschide ,o exposiţiune agricolă naţională şi de instrumente arătoare..." (Potra 1985, 63). Anunţul înseamnă că cea mai mare parte a fostului han fusese dărâmată, mai ales partea dinspre strada principală, aşa cum se vede întro hartă a capitalei dinspre finalul veacului al XIX-lea, devenind „Piaţa Constantin Vodă”, loc în care s-au improvizat şi alte întrebuintări publice, de la piaţă de bunuri generale, la corturi sau barăci de circ, iar în mai multe rânduri a servit şi de teatru (să zicem de ,varietăti”, cu tombolă și gimnastică).

Palatul Poștei, clădirea care adăposteşte acum Muzeul Naţional de Istorie a României, a fost ridicată în anii 1894-1900, după planurile arhitectului Alex. Săvulescu. Şi acest lucru s-a făcut cu destulă greutate, autorităţile fiind obligate să recurgă la exproprieri (Potra 1985, 56).

Refacerea documentaţiei istorice, în vederea publicării raportului, în anul 2011, a prilejuit găsirea pe Internet a lucrării lui George Florescu din 1935, care conţine hărţi ale Bucureştiului de la sfârş̧itul veacului al XVIII-lea, respectiv Sulzer (prefał̧ă), Purcel (p. 143) şi Ernst (p. 144). Dacă planul Sulzer, cel mai timpuriu (1781), conţine doar trama stradală, nefiind de mare ajutor, celelalte două, realizate de ofiţeri topografi ai armatei de ocupaţie austriece, între 1788-1991, conţin şi poziţionarea principalelor corpuri construite. Cele două planuri sunt aproape identice şi am ales pentru studiu pe cel care avea condiţia grafică cea mai bună, respectiv planul lui Ernst. Existenta acestui plan, de la finalul secolului al XVIII-lea, a permis o comparaţie directă cu planul lui Borroczyn de la 1854, exerciţiu care face obiectul unei planşe noi (PI. III/3), adăugate cu acest prilej.

Suprapunerea planurilor de la PI. III/3 arată, în primul rând, mari abateri reciproce, reflectând atât mijloacele modeste de care topografii dispuneau în epocă, cât şi relativa grabă în care s-au realizat desenele de la final de veac XVIII, în condiţiile unei ocupaţii cu durată necunoscută de executanţi. În ciuda acestor probleme, principalele ansambluri construite din zona noastră de interes se identifică relativ facil, îndemnându-ne a crede că între 1791 şi 1854 s-au petrecut destule schimbări, dacă nu în dispunerea principalelor monumente sau în trama stradală, atunci în organizarea lor de detaliu. Oricât de nefericite ar fi fost aproximările de măsurătoare şi desen, unele diferenţe între cele două planuri sunt prea mari pentru a nu semnala schimbări semnificative în teren. De exemplul, forma complicată a incintei nordice a Hanului Sf. Ioan cel Mare nu poate fi doar efectul unui desen greşit; de asemenea, poziţionarea bisericii Zlătari în unghi de $45^{\circ}$ fată de zidurile hanului perimetral - nu poate fi doar o „eroare" situaţiei de la Hanul Constantin Vodă, constatăm diferențe majore între cele două planuri. în desenul de la 1791 recunoaştem frontul în unghi obtuz, dinspre Podul Mogoşoaiei, închizându-se mult înainte de Uliţa Franceză. Adâncimea Hanului lui Constantin Vodă este mică, aripa de est fiind relativ aliniată cu spatele Hanului Zlătari, adică de circa două ori mai mică decât cea sugerată de planul din anul 1854; o altă diferentă notabilă este că flancul de la spate, de răsărit, nu este constituit de un simplu zid perimetral, ci de un corp de clădire impunător, care nu se regăseşte pe planul de la mijlocul veacului al XIX-lea. Între această latură din spate şi Hanul Stavropoleos se află nu numai o

\footnotetext{
${ }^{5}$ Biserica Zlătari s-a ridicat la început din lemn, de meşteri zlătari (aurari şi argintari), pe vremea lui Matei Basarab, şi a fost refăcută în piatră în vremea lui Şerban Vodă, conform inscriptiei de la 1850 (cu suficiente erori de identificare a personajelor, deci discutabil). La 1715 biserica primeşte parcelele din jur, pe care avea să se ridice Hanul Zlătari, pentru rotunjirea veniturilor lăcaşului. Cutremurele din anul 1802 și 1838 au afectat grav clădirea, care este reconstruită a fundamentis (,de iznoavă" spune George Florescu - 1935, 8) începând cu anul 1850. Ne putem întreba acum dacă biserica de la $1850 \mathrm{nu}$ a fost pusă pe cu totul alte fundaţii decât cele vechi, pentru a evita slăbiciunile structurale. Notele de săpătură ale lui Tíco $(1979,399)$, aşa sumare cum sunt, şi lipsite de desene, sugerează că în perimetrul blocului aflat la nord de Biserica Zlătari a cercetat parţial o biserică datată în veacul al XVI-lea, de tip navă, de maxim 15 m lungime, despre a cărei orientare însă nu se spune nimic (păcat, fiind probabil o orientare mai puţin obişnuită). Poziţionarea acestui vechi locaş corespunde planului Emst, spre marginea nordicã a Hanului Zlătari. Nu avem însă nici o certitudine, prima formă atestată a Bisericii de piatră Zlătari fiind dinspre finalul sec. XVII (Florescu 1935, 32), nu din sec. XVI...
} 
distantă apreciabilă (din motive lesne de înţeles, nu avem o scară...), dar şi două proprietăţi distincte, fără edificii. Uitându-ne acum pe haşurile planului Borroczyn, vedem în acelaşi loc, pe Uliţa Stavropoleos, o întrerupere de zid, cât şi o schimbare de unghi, care ar trebui interpretată ca sugestie a unei adosări constructive. Întreruperea nu este redată de planul de detaliu al lui Borroczyn (v. PI. II), însă exact în zona acelui unghi apare o întrerupere a succesiunii normale de camere, care reflectă aceeaşi împrejurare, respectiv adosarea segmentului estic al laturii nordice la o dată ulterioară. Evenimentul nu s-a putut produce decât între 1791 şi 1848 , pe loturile de proprietate vecine, dinspre Stavropoleos, achiziţionate probabil de mănăstirea Văcăreşti. Ideea unei extinderi a hanului ar trebui să fie anterioară anului 1821 , pentru că după această dată avem ştiri că hanul duce lipsă de muşterii, deci nu ar fi avut de ce se extinde.

Un ultim aspect am dori să clarificăm în această scurtă documentare. În raportul pentru săpăturile de salvare din anul 1978 , Cristian Tico $(1979,400)$ afirmă că a cercetat hanurile Zlătari şi Constantin Vodă. Perimetrul cercetat era cel pe care aveau să se construiască blocurile care flanchează, spre Calea Victoriei, Biserica Zlătari. Tico credea că la sud de biserica Zlătari a cercetat casele Bălăcenilor şi Hanul Constantin Vodă. Eroarea este doar parţial de înţeles. Este de înţeles, deoarece săpătura sa "căzuse" în curtea Hanului Zlătari, ceea ce crease impresia că laturile de nord, respectiv de sud ale hanului ar fi reprezentat două ansambluri distincte. După cercetarea noastră din anul 1996, care a surprins alinierea la stradă a hanurilor Zlătari şi Constantin Vodă, este foarte clar că Tíco s-a înşelat şi că trama stradală de acum este practic cea din secolul al XVIII-lea, cel puţin în perimetrul de referinţă. Eroarea s-a perpetuat, însă, fiind preluată, surprinzător, de G. Potra (1985, 5657, nota subsol); surprinzător, fiindcă specialistul vechiului centru istoric ar fi avut uneltele de a sesiza eroarea, cunoscând şi folosind în planşele sale planul Borroczyn (aici la PI. III/1; v. şi PI. III/3), pe care biserica Zlătari figurează în centrul hanului Zlătari.

Încă și mai surprinzător, colega noastră de atunci, Dana Mihai, care cunoştea săpătura din anul 1996 —publicând-o parţial, cum am mai spus - preia informaţia lui Tico necritic, fără a simţi nevoia de a o corecta (Mihai 2005, 274), reproducând toate informaţiile despre „Hanul Constantin Vodă”, grosimea zidurilor, mărimea cărămizilor şi alte tehnicalităţi, şi plasându-le drept termeni de comparaţie ai propriei cercetări de teren, deşi, la modul cel mai flagrant, Tico scria despre Hanul Zlătari ${ }^{6}$.

O eroare încă şi mai surprinzătoare face Dana Mihai (2005, $274 \mathrm{cu}$ nota 14) aducându-ne la cunoştinţă că ,primele investigaţii din această zonă, efectuate în anii '50, au dus la descoperirea temeliilor caselor Bălăceanu, ridicate peste fundaţiile altor construcţii, datate în secolele XIV-XV, cu ziduri foarte groase din cărămidă subţire şi piatră bolovănită de râu", făcând trimitere la cartea lui I. Ionaşcu din anul 1959, în fapt la capitolul semnat de Dinu V. Rosetti, despre cercetările arheologice de la Curtea Veche şi din zonă. Trimiterea domniei sale este la pagina 157 , unde - surpriză? - nici vorbă despre aşa ceva. Dacă ar fi avut curiozitatea de a vedea materialul publicat, domnia sa ar fi putut constata că pe chiar a doua pagină, 148 , se publica o hartã cu localizarea punctelor despre care se fácea vorbire, cel mai vestic dintre toate fiind la sud de Biserica Sf. Dumitru-Poştă. La pagina indicată, 157, Dinu V. Rosetti relata tocmai despre descoperirile din curtea bisericii, respectiv niște morminte, deducând existenţa altei biserici de la începutul veacului al XVI-lea sau poate de la sfârşitul celui precedent (contemporană, deci, cu nivelul cel mai timpuriu de aşezare pe care l-am cercetat noi, la cca. $150 \mathrm{~m}$ mai spre vest, v. secţiunea următoare), găsind şi temeliile unei biserici din secolul al XVII-lea (cea cunoscută ca

\footnotetext{
${ }^{6}$ Că se poate mai bine de atât, iar arheologii pot distinge, în principiu, cu uşurinţă, planurile evident diferite ale unor ansambluri arhitectonice separate de $o$ stradă, se poate constata în scurta notă a lui ManucuAdameşteanu (2005, 292-293), în cadrul cronicii săpăturilor arheologice din capitală, unde se referă la cercetările din lungul Căii Victoriei, între străzile Lipscani şi Stavropoleos, adresând exclusiv Hanul Zlătari, deşi evocă intervenţia lui Tico. Vezi şi Taloş 1980, care pleacă de la aceeași informaţie -săpătura lui Tico- dar ajunge la concluzia că Tico greşise, săpătura vizând exclusiv Hanul Zlătari, cele douã hanuri fiind separate de ulifa Stavropoleos.
} 
fiind „Biserica de Jurământ”), ridicată pe alt plan decât construcţia actuală. Că această biserică va fi fost paraclisul Bălăcenilor (Florescu 1935, 64) —foarte probabil! Însã nici urmă, sau spusă, despre casele Bălăcenilor, noţiune care implică o rezidenţă civilă, posibil şi plauzibil în vecinătate. Iată cum textele presei bucureştene de la mijlocul veacului al XIX-lea ${ }^{7}$, despre frumoasele case ale Bălăcenilor, devin aici certitudine ştiinţifică, pe spinarea unor trimiteri bibliografice aiuritoare.

\section{DESCRIEREA SĂPĂTURILOR DE SALVARE. PLANIMETRIE ŞI STRATIGRAFIE}

\section{Eugen S. TEODOR}

\section{3. a. Comentarii generale}

Preocupările Muzeului Naţional de Istorie pentru situaţia apărută pe Calea Victoriei au început încă din luna ianuarie 1996, când devenise clar că lucrările de aducţiune a apei distruseseră o parte a Hanului Zlătari. Nefiind deloc sigur că va exista posibilitatea unei cercetări arheologice propriu-zise în această zonă, fiindcă cele două conducte erau deja montate şi exista perspectiva plauzibilă că şanţul va fi astupat curând, s-a luat iniţiativa unei ridicări topografice, în ciuda vremii extrem de puţin propice, zăpada astupând rămăşiţele zidurilor. Pe această ridicare topografică au fost notate şapte ziduri, de la Z.1 la Z.7. Valoarea lucrării s-a demonstrat mai târziu a fi nulă, aşa cum era de aşteptat, dar a avut o consecinţă procedurală: zidurile la Hanul Constantin Vodă au fost apoi notate începând cu Z.8, pentru că, la acea oră, nu era clar unde se sfârş̧eşte un monument şi unde incepe celălalt. Numerele zidurilor, fiind doar o convenţie de notare, au fost păstrate şi pentru prezentul raport.

Lucrările de salvare la Hanul Constantin Vodă au început la jumătatea lunii februarie 1996 prin trasarea şanţului pentru conducta de apă; acesta fusese deja introdusă şi la intersecţia străzii Stavropoleos cu Calea Victoriei (v. planul general la PI. I), perforând extremitatea de vest a incintei de

\footnotetext{
${ }^{7}$ Buletinul Municipiului București, III, 1861, nr. 25, 17 mai, apud Potra 1985, 63.
}

$\mathrm{N}$, zid (fundaţie) care figurează în plan ca $\mathrm{Z}$. 9 (v. Pl. IV). Datorită dorinţei constructorului de a finaliza lucrarea cât mai repede, decaparea mecanică s-a făcut până la aproximativ $-1,5 \mathrm{~m}$, pentru o zonă care corespunde pe plan Camerelor 1-7. Au fost cruţate zidurile hanului, la o cotă de aprox. $0,8 \mathrm{~m}$ sub asfaltul Căii Victoriei. Această acţiune s-a mai datorat concepţiei larg răspândite că, la un monument, ceea ce contează ar fi numai zidurile. Nu e mai puţin adevărat că arheologii aveau convingerea că, în plin oraş, sub Calea Victoriei, straturile arheologice ar trebui să fie deranjate, sau să conţină moloz până la o adâncime apreciabilă; în plus, decaparea s-a produs în pământ înghețat, amestecat cu zăpadă, ceea ce a făcut imposibilă o observaţie atentă din primul moment. Prezumţiile s-au dovedit greşite, atât zidurile, cât şi straturile arheologice ale hanului începând practic imediat sub cămaşa asfaltică pluristratificată, groasă de circa $0,4 \mathrm{~m}$. Decaparea până la 1,5 m a mai avut drept consecinţă, în afară de distrugerea nivelelor hanului, distrugerea instalaţiilor mai vechi de aducţiune a apei, cât şi a canalizării actuale, cu efecte incomode pentru lucrările din următoarele luni, lucrătorii muncind mai mult pentru scoaterea apei rezultate din cele cinci ninsori care au urmat, a apei scurse din rigolele străzii Stavropoleos (canalizarea fuind înfundată), dar și a ,izvoarelor" locale, din ţevile sparte. Fără a dori să plictisim cu istoria dezastrelor cotidiene dintr-un şantier de salvare, trebuie să menţionăm că astfel de situaţii ne-au obligat să părăsim cercetarea jumătăţii de nord a Camerei 1 (notată la Pl. IV cu „C.1”), a extremităţii de nord a casetei, dar şi a părţii de vest a Camerei 3 . Chiar nedistruse, astfel de conducte de la începutul secolului $\mathrm{XX}$ au provocat dificultăţi stratigrafice, în special în Camera 9 şi în centrul casetei aflată la est de camerele numerotate 1 şi 2.

Constatările făcute la camerele 1-7 neau determinat să insistăm ca decaparea mecanică făcută spre sud de C.7 să fie de maxim $0,6 \mathrm{~m}$, pentru a putea cerceta efectiv prin săpătură nivelurile proprii ale hanului. Diferenţele stratigrafice observate între C. 8 şi camerele 1-7 ne-au determinat apoi să solicităm constructorului deschiderea casetei (notată Caseta Est, în dreptul primelor două 
camere, pe trotuar), pentru a putea face observaţii stratigrafice amănunţite şi pe latura de nord a monumentului. Nici acolo nu am avut foarte mult noroc, după cum se poate observa pe plan, o săpătură propriu-zisă neputându-se face decât în C.2, şi pe exteriorul clădirii, în marginea străzii Stavropoleos, însă numai până la $1,6 \mathrm{~m}$ (zona fiind inundată repetat, inclusiv de ţevi fisurate).

Vremea rece şi umedă a creat nu numai probleme arheologice (unele profile fiind refăcute complet și de cinci ori), dar şi de protecţie a muncii. Deși profilele nu au fost lucrate vertical, ci cu o înclinare de 4-5 grade, ştiindu-se cât de friabile sunt depunerile medievale (insuficient tasate şi cu o componentă organică marcată) şi apreciind că grosimea depunerilor, de peste doi metri (dar şi peste trei metri), prezintă un risc mare de surpare, incidentele de acest fel nu au putut fi evitate. Crăpături verticale au apărut pe profile încă de la sfârşitul lunii martie, când temperaturile de noapte au devenit pozitive, producându-se primele surpări. Ploile puternice de Paşti (14 aprilie 1996) au înrăutăţit mult situaţia. S-a prăbuşit întâi profilul (de est) al Camerei 6, apoi, la intervale de timp, al C.7, C.8 şi C.1 antrenând, de fiecare dată, 6-7 metri cubi de pământ, respectivele perimetre fiind părăsite, pentru a nu risca un accident; iar unele obiective nu au mai putut fi finalizate, profilul de la C.6 rămânând nedesenat, iar în C.7 abandonându-se săparea unei locuinţe anterioare hanului.

Colectivul a încercat să folosească oportunitatea acestui şantier de salvare pentru a testa în condiţii deosebite unele practici de săpătură moderne, cum este metoda unităţilor stratigrafice (US). Împărţirea şantierului în unităţi teritoriale în sistem grilă a eşuat, marcajul cu vopsea fiind acoperit permanent de zăpadă şi noroi; aceleaşi marcaje, făcute cu sfoară pe profile, au fost repetat distruse de surpări. Aceste împrejurări ne-au determinat să revenim la un sistem de orientare şi clasare a suprafeţelor în funcţie de limitele oferite de zidurile hanului, care împărţeau secţiunea în suprafeţe relativ egale. De aceea, într-o expresie ca cea de mai sus, „locuinţa din camera 7", camera (C.) 7 are înţelesul unei unităţi teritoriale, echivalente logic noţiunii de carou (sau alte noţiuni care definesc suprafeţe mici).

$\mathrm{Cu}$ înregistrările de ,unităţi stratigrafice" s-a insistat ceva mai mult, majoritatea înregistrărilor de pe şantier fiind de acest tip. Problemele au venit din relativa lipsă de experienţă cu acest tip de înregistrare, din caracteristicile şantierului (odată intrat într-o „cameră” nu se mai vedea nimic altceva, din pricina zidurilor despărţitoare), din imposibilitatea de a ţine permanent luneta topografică în stradă, dar mai ales din lipsa personalului suficient pentru o metodă atât de meticuloasă. Acest tip de înregistrare a fost părăsit în perioada finală a şantierului (luna iunie), când termenul de predare a lucrării a constrâns la metode mai operative. Metoda US-urilor nu a fost aplicată, fireşte, nici în prima lună de lucru, când era practic imposibil.

Metodologic, acest şantier a fost atât prilejul unor experimente şi expediente, dar şi a unor concluzii vis-à-vis de utilitatea unor metode şi practici în condiţiile arheologiei urbane în anotimp rece; una deosebit de evidentă, care poate nici nu ar mai trebui menţionată, este că lucrările de iarnă trebuie evitate. Dacă totuşi apar considerente mai importante este bine de reţinut că vor rezulta cheltuieli mari şi câştiguri (ştiinţifice) mici. $\mathrm{O}$ a doua concluzie este că metoda unităţilor stratigrafice, aplicată în integralitatea ei, este mult prea lentă pentru o săpătură de salvare sau preventivă, indiferent de anotimp. Mai mult decât atât, pentru arheologia evului mediu, care negociază atât de frecvent cu umpluturi menajere, înregistrarea completă a fiecărui strat presupune o muncă imensă, cu profit discutabil. Pe de altă parte, metoda unităţilor stratigrafice are avantaje care nu pot fi neglijate, între care am enumera 0 înregistrare mult mai obiectivă și mai sistematică, posibilitatea lucrului în ture şi în echipă, compatibilitatea cu sistemele informatice. În concluzie, ar fi de meditat la o adaptare a metodei unităţilor stratigrafice pentru cercetările de salvare, dar, în acelaşi timp şi din acelaşi motiv, la calibrarea corectă a colectivului necesar unei asemenea cercetări. 


\section{3.b. Consideraţii stratigrafice generale}

Secţiunea care a făcut obiectul cercetării arheologilor de la Muzeul Naţional de Istorie, care traversează extremitatea de vest a Hanului Constantin Vodă, a fost locuită şi înainte de sfârşitul secolului al XVII-lea, când a fost ridicat monumentul. Această locuire nu pare să coboare însă mai jos de sfârşitul secolului al XV-lea, şi este de pus în legătură, evident, cu începuturile Curţii Domneşti. Doar două fragmente ceramice sunt cert mai vechi, datând probabil din secolul al IV-lea, găsite în dreptul camerelor 1 şi 2, indicând proximitatea unor complexe din această epocă. Nu există însă nici un complex arheologic mai vechi de secolul al XV-lea. Stratul arheologic cel mai vechi suprapune o argilă cu mult pietriş, iar complexele cele mai vechi se adâncesc întrun prundiş în care alternează straturile de nisip cu bobul mare şi cele cu pietriş mic. Configuratia zonei nu s-a schimbat prea mult de la 1848 , aşa cum se poate vedea la $\mathbf{P l}$. III/1, cotul Dâmboviţei din dreptul Podului Mihai Vodă fiind, poate, mai accentuat ${ }^{8}$. Configuraţia terenului în secţiunea noastră nu s-a schimbat practic deloc, panta principală coborând de la $\mathrm{N}$ la $\mathrm{S}$, fapt ilustrat la $\mathbf{P l}$. $X I / 1$, unde se poate vedea cum cotele asfaltului şi cotele nivelului steril arheologic formează, cu aproximaţie, două curbe paralele. Exista, probabil, şi o uşoară pantă $\mathrm{E}-\mathrm{V}$, având în vedere proximitatea Dâmboviţei, dar acest lucru nu poate fi evidenţiat pe o secţiune $\mathrm{N}-\mathrm{S}$.

\section{3.c. Locuinţele}

\section{Locuinfa l. Complexul a preces} Locuinţa 2, fiind tăiat de aceasta, şi se află în unitatea teritorială denumită Camera 5 . Puţinele date pe care le avem despre complex ne sugerează că ar fi fost un bordei. Marginea gropii bordeiului a fost surprinsă la $-1,9 \mathrm{~m}$ faţă de asfalt (cota generală -356 ) şi se adâncea $0,75 \mathrm{~m}$ în solul viu. Ceea ce s-a mai păstrat arată un colţ rotunjit, sugerând orientarea SE-NV (v. Pl. IV), având alăturat groapa unui stâlp de colţ, din lemn, cu diametrul de $30 \mathrm{~cm}$; din acest complex s-au recoltat câteva fragmente ceramice, databile

\footnotetext{
${ }^{8}$ Albia naturală a Dâmboviţei trecea, cu aproximaţie, pe traseul actualelor străzi Domniţa Anastasia şi Ilfov.
}

la sfârşitul secolului al XV-lea sau începutul următorului, şi câteva oase.

A existat varianta de interpretare că această amenajare ar putea fi o instalaţie de acces la pivniţa Locuinţei 2. Poziţia bârnei de colţ, care împiedică accesul spre pivniţă cu un obiect mai voluminos, cât şi dificultatea de a folosi ,treapta" realizată de podeaua L.1 pentru a coborî în pivniţa L.2, datorită diferenţelor mari de nivel, elimină această posibilitate.

Locuinta 2. Complexul este desfăşurat în camerele 4 şi 5 , de-a lungul Zidului 8 (zidul de incintă al hanului) și este o locuinţă cu pivniţă, lungă de cel puţin $8,5 \mathrm{~m}$ (nu ştim unde era colţul de NV al complexului, dar, foarte probabil, undeva sub intersecţia $Z .8$ şi Z. 12). Adâncimea originară a complexului a putut fi măsurată pe profilul de nord al camerei 4 , sub fundaţia $Z$. 12 , fiind de 1,35 $\mathrm{m}$. Pivniţa este săpată în solul viu —depuneri aluvionare, alternând pietrişul cu nisipul cu bob mare. Podeaua nu este perfect dreaptă, nici perfect orizontală, fiind înclinată uşor spre sud, adâncindu-se până la $3,55 \mathrm{~m}$ sub Calea Victoriei (cota de şantier -515). Fără a fi groasă (circa $3 \mathrm{~cm}$ ), podeaua este amenajată cu grijă, rezultând o crustă foarte rezistentă, cu aspect feruginos, puternic bătută şi posibil arsă (a fost confundată, la început, cu o podea de cuptor, ceea ce la adâncimea aceea era oricum neplauzibil). Explicaţia unei amenajări atât de temeinice stă în pericolul permanent pe care îl reprezenta pânza freatică, care a făcut destule probleme şi lucrărilor şantierului nostru.

Locuinţa se înălţa pe suportul unor bâme-talpă, culcate de-a lungul marginii interioare, cu secţiune aproximativ pătrată, cu latura de circa $15 \mathrm{~cm}$; pe aceste tălpi se sprijineau bâme verticale, cu secţiune rotundă, cu diametrul de 17-20 cm; urme de acest fel au fost găsite la colţul de SE, la extremitatea de $\mathrm{N}$ (care este, probabil, colţul de NE) şi la 2,9 m sud de aceasta din urmă, împărţind parterul înalt al locuinţei în două părţi inegale $(4,5+2,9 \mathrm{~m})$. Nu se poate certifica existenţa bârnei-talpă pentru latura de sud.

Locuinţa a avut cu siguranţă două faze de evoluţie, surprinzându-se elemente certe din două rânduri de podea, două rânduri de bârne-talpă şi chiar un dublu stâlp de colţ, la $\mathrm{SE}$, despărţite de un strat de nisip, gros de 
10-20 de cm, însemnând că locuinţa a fost inundată; a doua podea a pivniţei a fost deci amenajată mai sus, dar cu aceeași grijă ca prima oară, fiind la fel de compactă şi impermeabilă.

Umplutura pivniţei este reprezentată de o masă mare de bârne, groasă de $30-40$ de $\mathrm{cm}$, cu aparentă de incendiu, bârnele fiind complet carbonificate; consistenţa păstoasă a resturilor de lemn şi aspectul negru-omogen în secţiune indică însă mai degrabă carbonificarea naturală (lemnele arse au duritate crescută). Restul umpluturii este reprezentat de pământ de coloratură organică, scurs printre bâmele prăbuşite ale parterului şi acoperişului, precum şi chirpici ars, în mari cantităţi, în special spre colţul de SE; o mare parte a acestuia o reprezintă însă nu urmele de incendiu, ci resturi masive dintr-o instalaţie de foc cu performanţe bune (la interiorul acestei instalaţii se dezvoltau temperaturi de peste $1100^{\circ} \mathrm{C}$, lutul luând o culoare albastru-vineţie şi o duritate excepțională, care se mai întâlnește la cuptoarele metalurgice); rostul acestei instalaţii de foc nu poate fi precizat, existând mai mult evidenţe negative: nu există nici cea mai mică urmă de zgură pe bucăţile de lut ars şi nu există nici un fragment de cahlă sau oală-cahlă, eliminându-se, atât varianta unei instalaţii metalurgice, cât şi varianta unei sobe clasice.

Dacă culoarea bârnelor nu indică cu necesitate un incendiu, acesta este totuşi cauza sfârşitului acestui complex, fiindcă peretele de sud s-a prăbuşit peste pivniţă, întreg şi ars la roşu (pereţii fiind de chirpici, pe structură de lemn), acoperind toată umplutura descrisă mai devreme ${ }^{9}$; măsurat în profil, peretele prăbușit avea $20 \mathrm{de} \mathrm{cm}$ grosime. Din acest complex provine singura piesă ceramică întreagă (PI. VII/34, un ulcior care poartă și el urmele evidente ale

\footnotetext{
9 Din nou - foarte interesante observaţiile sedimentologului, realizate pe profilul vestic al „,camerei 4”, sub fundaţiile Hanului. Îmi permit şi eu, aici, un comentariu. Podeaua de lemn constatată de C. Haită nu poate aparţine beciului clădirii, ci podelei parterului prăbuşit în beci; de aici și observaţia că între amenajarea iniţială şi podea există o umplutură aluvială (secventa fiind că beciul a fost inundat, apoi clădirea a colapsat, în proces producându-se şi un incendiu, probabil în perioada dezgheţului). Vezi secţiunea 6 a raportului.
}

incendiului, protejat prin hazardul bâmelor prăbuşite.

Fundaţiile hanului nu suprapun direct rămăşiţele acestei locuinţe. Între fundaţia Z.8 (incinta hanului) şi peretele incendiat şi prăbuşit al locuinţei se află încă un strat, conţinând diverse deşeuri, inclusiv mortar şi resturi de cărămidă, elemente care lipsesc în umplutura inferioară a pivniţei. Concluzia care se poate trage de aici este că între distrugerea prin incendiu a locuinţei şi construcţia hanului a trecut o bucată de timp, groapa fostei pivniţe fiind folosită ca groapă de gunoi. $\mathrm{O}$ a doua concluzie este că în proximitate au existat construcţii de cărămidă mult înaintea hanului ${ }^{10}$. Apoi zona a fost mai mult sau mai puţin părăsită, fiindcă toate aceste straturi de destrucție sau menajere sunt acoperite de un strat gros (pe profilul de $\mathrm{S}$ al camerei 4 , de până la $0,70 \mathrm{~m}$, reprezentând umplutura superioară a fostei pivniţe) de pământ negru-verzui (,pământ de mlaştină”) cu rare urme antropice (pigment cărbune şi fragmente mărunte de chirpici), practic - un strat gros cvasi-steril arheologic; intervalul de timp între distrugerea locuinţei şi construcţia hanului ar trebui să fie, ca ordin de mărime, de cel puţin câteva decenii. Aceste concluzii stratigrafice sunt confirmate de analiza materialului ceramic.

Locuinţa 3. Această locuinţă a apărut în unităţile teritoriale numite Camerele 8 şi 9. Groapa locuinţei a apărut la $-1,70 \mathrm{~m}$ şi se adâncea $1,3 \mathrm{~m}$, până la cota -305 sub asfalt. Latura de nord a L.3 a apărut pe mijlocul camerei 8 , de-a lungul acesteia găsindu-se, la interior, o bârnă-talpă groasă de $10 \mathrm{~cm}$ şi lată de $20 \mathrm{~cm}$. Latura de vest a locuinţei s-a profilat de-a lungul incintei hanului, continuându-se în Camera 9, dispărând undeva sub martorul lăsat ca sprijin pentru conducta de apă ce aprovizionează Muzeul Naţional. La colţul de NV al locuinţei a apărut urma unui stâlp rotund, foarte gros, cu diametrul de $40 \mathrm{~cm}$. La 1,60 m spre est, pe aceeaşi latură de nord, a apărut o a doua urmă de stâlp, de data aceasta mult mai modestă, cu un diametru de circa $15 \mathrm{~cm}$. Podeaua pivniţei a fost amenajată şi în acest caz cu

10 Ar putea fi vorba despre evocatele case ale Bălăcenilor (vezi secțiunea anterioará a raportului), care însã nu se află în perimetrul cercetat. 
grijă, rezultând o crustă suficient de rezistentă pentru a nu putea fi străpunsă cu şpaclul, având însă o culoare verzuie. Podeaua nu era perfect orizontalizată, la martorul de sud al Camerei 8 apărând şi o alveolă, făcută, se pare, cu bună ştiinţă, cu diametrul de 60-65 $\mathrm{cm}$ şi adâncă de $15 \mathrm{~cm}$. Pe podea nu există urme de incendiu, iar obiectele arheologice au fost rare. $\mathrm{Nu}$ există, de asemeni, decât foarte puţini martori posibili ai suprastructurii locuinţei. Umplutura locuinţei începe cu un strat gros de pământ nisipos, de circa 15-17 $\mathrm{cm}$, fără urme antropice. Peste acest strat este suprapus un altul, şi mai gros, de grosime variabilă (mai gros la margini, deci aruncat în marginile gropii), compus din lut galbenroşcat, neomogen, cu pământ negru-vineţiu şi urme de pigment de lemn ars. După acest moment, groapa locuinţei a devenit groapă menajeră, cu conţinut organic (negru, afânat) alternând cu straturi de cenuşă şi depuneri de lut pentru igienizare, umplutură având toate componentele menajere cunoscute (cioburi, oase, chirpici). Dacă numărul de lutuieli corespunde numărului de veri, groapa de deşeuri a funcţionat circa 4 ani; dar, posibil, mai mult. În fine, pe centrul gropii ultimii 50 $\mathrm{cm}$ de umplutură par a reprezenta un strat de abandon, omogen, negru-brun cu tente verzui, cu componente antropice puţine, în special urme de lemn ars.

Revenind la cele expuse la descrierea stratigrafiei inferioare a gropii, explicaţia acestei succesiuni pare a fi una singură: locuinţa a pierit datorită unei inundaţii, dar a uneia suficient de puternice pentru a fi luat suprastructura, din care nu mai găsim resturi. Stratul egal de nisip mâlos de pe podeaua pivniţei reprezintă ceea ce a rămas după resorbţia apelor ${ }^{11}$, în timp ce stratul superior se datorează unei curăţenii la suprafaţă, făcută de cei care încercau să reia locuirea zonei.

Sunt de remarcat câteva asemănări între locuinţele 2 şi 3: adâncimea gropii, bârna-talpă pe o latură (pe lungime), stâlpii de colţ, bârnele de separare a parterului, amenajarea podelei. Cunoscând câte o

\footnotetext{
1 Această interpretare a venit aproape de la sine. În timpul acestor săpături am avut ocazia de a face şi arheologie experimentală, camerele hanului fiind în câteva rânduri pline-ochi cu apă; ceea ce a rămas în urmă era acelaşi strat de mâl nisipos.
}

dimensiune la fiecare locuinţă şi ţinând cont de numeroasele asemănări, putem trage concluzia, fie şi ipotetică, a dimensiunilor acestor locuinţe: $8,5 \times 4 \mathrm{~m}$, ceea ce se încadrează în dimensiunile obişnuite pentru asemenea construcţii ${ }^{12}$. Sunt amândouă locuinţe cu pivniţă, iar prima lor fază de evoluţie a fost foarte probabil strict contemporană, fiind încheiată prin aceeaşi inundaţie. Amândouă umpluturile superioare sunt încheiate cu un strat de abandon. Dacă interpretarea aceasta este corectă, faza a doua a L.2 a durat numai câţiva ani.

La sud de martorul (postamentul ar fi un termen mai exact) lăsat pentru ţeava de apă, în aceeaşi Cameră 9 , există amenajări care, destul de sigur, sunt legate de locuire. Faptul că nu s-a putut surprinde, pe centrul şi în sudul C.9, nici o latură a complexului, nici un element caracteristic (o vatră, de pildă), împiedică $o$ opinie clară referitoare la funcţionalitatea complexului. $\mathrm{Ca}$ ordin de posibilitate, ar putea fi o locuinţă de tip bordei, cu gârliciul spre sud, sau o altă amenajare, legată chiar de locuinţa cu pivniţă alăturată. Eventuala relaţie stratigrafică a rămas însă sub martorul amintit.

Locuinta 4. Așa cum am mai spus, Camera $7 \mathrm{nu}$ a fost săpată integral, datorită prăbuşiri malului de est. Existenţa acestei locuinţe este doar dedusă, însă există relativă certitudine că presupunerea este întemeiată; scufundarea nivelelor hanului, în Camera 7, cu până la $0,5 \mathrm{~m}$, pe o lungime de profil de 3 metri, forma determinată prin săpătura în suprafałă a acestei scufundări, în fine, complexul 16 din colţul de NE al Camerei 8, toate conduc la concluzia unei locuinte adâncite. Complexul 16 este o zonă restrânsă de lut cruţat, la o adâncime de $-1,8 \mathrm{~m}$, având în mijloc săpată $o$ groapă rotundă, cu diametrul de $45 \mathrm{de} \mathrm{cm}$. şi adâncă de $30 \mathrm{de}$ $\mathrm{cm}$, având pe fund două fragmente inferioare de oală. Groapa ar putea fi confundată cu urma unui stâlp de colţ al locuinţei, dar profilul arcuit al gropii şi absenţa urmelor de lemn ne împiedică a o considera astfel. Foarte

\footnotetext{
${ }^{12}$ Dimensiunile sunt similare altor locuinţe cu pivniţă săpate de aproximativ același colectiv, la Brănești, în 1992 (Păunescu, Teodor 2003) și la Orașul de Floci, în 1994-1996 (Chiţescu, Teodor 1997 - cu referire la prima parte a raportului, despre cercetările din Grindul 1, respectiv L.5).
} 
probabil că locul era destinat păstrării în siguranţă a oalelor (fiind deci, funcţional, un „bufet”). O amenajare similară (complexul 19) apăruse spre colţul de NE al C.7, fiind delimitată în grund la $-2,15 \mathrm{~m}$ (cotă de la asfalt), cu dimensiuni asemănătoare, dar nu a putut fi cercetată în amănunţime din cauza prăbuşirii malului. Aceste complexe ne indică tipul generic al Locuinţei 4, excluzând posibilitatea unei locuințe cu pivniţă şi indicând o locuinţă tip bordei, în care asemenea laviţe cruţate (sau amenajate din lut) sunt obişnuite. Planul locuinţei trebuie să fi fost apropiat de cel sugerat în planul general al săpăturii de la Hanul Constantin Vodă (Pl. IV), locuinţa având o lungime de 4,5-5 $\mathrm{m}$ pe direcţia SV-NE şi o lăţime surprinsă pe $3,5 \mathrm{~m}$.

Locuinta 5? Existenţa acestei locuinţe este problematică. Solul viu a fost atins în jumătatea sudică a Camerei 1 (singura disponibilă cercetării, cealaltă jumătate funcţionând pe rol de lac de acumulare) la 2,3 $\mathrm{m}$ adâncime faţă de asfalt. Această adâncime este comparativ prea mare, în camera alăturată solul viu fiind atins, lângă $Z .10$, la $1,8 \mathrm{~m}$. În plus, deasupra solului viu este amenajat un strat subţire de lut bătut, dar aproape la fel de dur ca cele întâlnite în L. 2 şi L. 3. În profil a fost surprinsă şi o urmă de par cu diametrul de $9 \mathrm{~cm}$, adâncă de $25 \mathrm{~cm}$. $\mathrm{Nu}$ există urme evidente de la o suprastructură prăbuşită, dar nici indicii de inundaţie. Materialul ceramic recoltat la acest nivel este destul de sărac şi inexpresiv.

Locuinta 6? Apare în colţul de SE al Camerei 6, la $-1,8 \mathrm{~m}$ (nivelul cel mai vechi de locuire) şi se adânceşte până la $-2,5 \mathrm{~m}$; are formă neregulată, fiind, posibil, gârliciul şi latura de vest a unei locuinţe de tip bordei; conţine lemn carbonizat (suprastructura?), chirpici ars, urme de mortar în umplutura superioară; aceste urme de mortar, fiind pe un nivel care precede construcţia hanului, se constituie într-un alt argument pentru construcţii de cărămidă care au preces Hanul Constantin Vodă, într-o zonă proximă celei cercetate.

Locuinţa 7 ? Lângă zidul 20 , care mărgineşte la sud Camera 10 , la -210 , au apărut elemente din prăbuşitura unei sobe, cu fragmente de oală-cahlă decorată cu motive vegetale. Problema care se pune este dacã aceste elemente sunt sau nu în poziţie secundară (aruncate într-o groapă). Profilul inferior al C. 10 poate sugera existenţa unei gropi de mari dimensiuni, la -230 existând un strat de pământ negru-cenuşos, cu pigment de cărbune şi pigment de mortar (!), suprapus de un strat de lut depus, toate acestea pe o lungime de profil de $3,50 \mathrm{~m}$. Prezenţa resturilor de sobă conduce ipoteza de lucru către varianta unei locuinţe cu pivniţă. Din nefericire şi acest punct de lucru a trebuit părăsit înainte de încheierea cercetării, datorită riscului de prăbuşire a malului.

\section{3.d. Necropola}

Zona a fost intens locuită în secolul al XVI-lea, cu excepţia extremităţii de sud a secţiunii. Am fost foarte surprinși să constatăm că, pe sectorul de 5 metri de la exteriorul incintei de vest a hanului, aflat la numai 20 de metri de o locuintă, am recuperat un singur fragment ceramic smălţuit din secolul al XVI-lea, lipsind, în general, orice alte urme antropice (materiale de construcţie, oase de animale, arsură); solul pe care se aşezau amenajările contemporane hanului avea o culoare negricios-verzuie (numit uneori ,pământ de mlaştină”), dens şi cleios. Presupunerea că zona era inundabilă, pe baze cvasi-permanente, nu se susţinea, cotele fiind similare celor din locuinţele de la nord. Explicaţia a venit mai târziu, când săpătura din C.11 s-a apropiat de cota finală. La $-2,30$ $m$ a fost descoperit un schelet uman în poziţie anatomică, notat M.1. Poziţia scheletului este una rituală obişnuită, cu antebraţele aduse pe abdomen, de la jumătate în jos intrând sub profilul de est al secţiunii. $\mathrm{Cu}$ excepţia rămăşiţelor de la lemnul sicriului, mormântul nu are alt inventar, dar poate fi datat destul de bine după contextul stratigrafic. Groapa mormântului se distingea clar de la $-1,8 \mathrm{~m}$, partea sa superioară fiind distrusă de nivelarea care a preces construcţia hanului, şi se adâncea într-un pământ argilos, cu sporadice urme de lemn ars. Aşadar, mormântul nu aparţine nivelelor de locuire cele mai vechi, fiindcă se adâncește în aceste nivele, şi precede cu puţin construcţia hanului.

Resturi sporadice de la un al doilea mormânt (M.2), împreună cu un inel, au fost găsite la 1,2 m N de M.1, într-o groapă notată 
complexul 29, intersectată de profil, cu formă în plan ovoidal-prelungită, cu lăţimea de 0,35 m şi o lungime (incompletă) de $0,50 \mathrm{~m}$. Această groapă a fost surprinsă în profil de la $-2,22$ la $-2,62$ m și perforează o altă groapă, de data aceasta menajeră (complex 28), care conţine ceramică din a doua jumătate a secolului al XVI-lea. Prin dispunerea oaselor - aară relaţie anatomică, dar şi prin forma gropii- prea mică pentru un adult, cât şi prin profilul gropii, cu fundul arcuit, M.2 nu poate fi decât o reînhumare, mai exact de strămutare $^{13}$. Intrigă, totuși, adâncimea mare la care a fost săpată groapa de reînhumare, M.2 aflându-se cu $0,2 \mathrm{~m}$ mai jos decât M.1. Problema este parţial solubilă, groapa M.2 fiind săpată într-o altă groapă, putând presupune şi chiar observa tasarea acesteia; chiar şi aşa, M.2 este la o adâncime prea mare, fiindcă nu există nici un motiv de a îngropa adânc oasele reînhumate. Cazuistica reînhumărilor şi strămutărilor fiind însă foarte săracă în arheologia românească, nu am făcut aici decât să descriem situaţia mai amănunţit şi să atragem atenţia asupra a ceea ce ni s-a părut curios, fără a ne îndoi prea mult de funcţionalitatea precizată a complexului.

Fără o legătură nemijlocită, trebuie amintit aici că la curăţenia efectuată după o ploaie, în nivelurile superioare ale hanului, în C.12 (cameră care nu a putut fi săpată, spaţiul fiind prea îngust), la adâncimea de $0,5 \mathrm{~m}$, a fost găsit un alt os uman. Acesta a putut ajunge într-o poziţie atât de înaltă cu prilejul uneia dintre numeroasele nivelări cu pământ adus, pentru reamenajarea hanului (v. infra), sau a fost adus spre suprafaţă de o groapă târzie, de după jumătatea veacului al XIX-lea. Cert este că, având rămăşiţe de la 3 morminte diferite, la interval de numai câţiva metri, se exclude varianta unor înmormântări întâmplătoare, într-un spaţiu neorganizat ${ }^{14}$.

\footnotetext{
${ }^{13}$ Cercetările de la Brăneşti-Vadu Anei, din anul 1992 (Păunescu, Teodor 2006) arată că strămutările de morminte (situaţie indicată de faptul că reînhumarea nu este datorată reutilizării mormântului pentru un alt defunct) sunt ceva destul de obişnuit în epocă (sec. XVI), inclusiv în mediul rural.

${ }^{14}$ Astfel de situaţii am întâlnit la Brănești, unde un mormânt cu inventar tipic din sec. XVI (Păunescu, Teodor 2006, 307, M.445) avea scheletul orientat E-V (invers), fiind la peste 30 de metri de necropolă, dar și la Oraşul de Floci, unde au fost întâlnite de asemenea înmormântări izolate.
}

Mai mult decât atât, în afara celor 3 morminte certe, este de semnalat că stratigrafia inferioară a C.10 şi C.11 prezintă şi alte gropi care ar fi putut fi gropi de morminte, având dimensiuni obişnuite şi profile uşor lărgite (mai largi sus şi cu marginile ceva mai înclinate decât normal), care nu sunt gropi menajere, lipsind categoriile de inventar tipice, dar care nu au furnizat nici un os uman. Unele dintre acestea ies din discuţie, nefiind săpate complet (cele din C. $10^{15}$ ), dar alte două gropi, din C.11, pot face obiectul unei speculaţii (v. infra, complexele 35 şi 38 ). Se poate presupune că aceste gropi sunt foste morminte, strămutate în momentul construcţiei hanului. $\mathrm{O}$ asemenea atenţie ar putea să pară surprinzătoare, mai ales că, în situaţie similară şi aproximativ în acelaşi timp, mormintele de la Zlătari erau suprapuse de zidurile hanului de acolo. Dacă ne raportăm la toate datele pe care le avem, atât cele arheologice, care ne indică faptul că mormintele nu aparţin cartierului alăturat de locuințe de la nord, ci sunt mai târzii, adică din secolul al XVII-lea, când, ne spun documentele, întreaga zonă în discuţie devenise proprietatea Bălăcenilor ${ }^{16}$, putem presupune că cimitirul aparţinea acestora. Că cei înhumaţi aparţineau chiar familiei sau unor apropiaţi sau servi, este o altă discuţie. Putem înţelege însă grija acestora de a muta mormintele în momentul când pământul a fost confiscat de Brâncoveanu. Este interesant că mărturii pentru asemenea practici avem, cel puţin aparent, atât referitor la momentul iniţial al prezenţei acestui grup uman în zonă (M.2 este martorul acestei faze), cât şi la momentul schimbării de destinaţie a pământului, adică la momentul construcţiei hanului (complexele 35 şi 38). Toate acestea sunt ipoteze şi nu ar putea fi altceva. Aceste ipoteze însă sunt singurele care pot da explicaţii mulţumitoare situaţiei de pe teren. Cel puţin aparent.

\footnotetext{
15 Apariţia unor crăpături adânci în profil a dus la abandonarea săpăturii, pentru a nu pune în pericol viaţa lucrătorilor, având în vedere ceea ce se întâmplase trja cu profilele de E ale Camerelor 6, 7 şi 8.

${ }^{16}$ Vezi secţiunea anterioară a raportului.
} 


\section{3.e. Alte complexe ale locuirii anterioare hanului}

Locuirea presupune, cum e firesc, şi alte complexe decât locuinţele propriu-zise. Acestea sunt gropi, de diverse forme şi funcţionalităţi, nu totdeauna posibil de precizat. Unele dintre aceste complexe ar putea să nu fie legate de activităţile curente, ci de necropolă. Săpătura incompletă nu permite clarificarea situaţiei la nivelul dorit, dar considerăm firesc să facem menţiunea ipotetică a unei atribuiri sau a celeilalte. Nefiind vorba de complexe deosebite sau foarte relevante, vom face o simplă enumerare a acestora, identificate după numărul de şantier.

Complexul 2. Groapă în C.2, tăiată de profilul de $\mathrm{E}$, cu diametrul de $2 \mathrm{~m}$, se adânceşte de la $-1,75 \mathrm{~m}$ (cotele sunt, toate, de la asfalt). Umplutura este predominant cenuşoasă, înclinată pronunţat spre sud; până la $-3 \mathrm{~m}$ se găsesc diverse straturi de nisip, cu o pronunţată înclinaţie de la $\mathrm{N}$ spre $\mathrm{S}$, mai accentuată decât înclinaţia naturală (straturile de nisip, teoretic pluviale, ar fi trebuit să contribuie la nivelare, nu la accentuarea diferenţelor). Această stratigrafie interioară a gropii este o curiozitate, singura explicaţie pe care o putem oferi ar fi aceea că groapa a fost utilizată numai dinspre nord, deservind deci o locuinţă aflată în afara perimetrului cercetat, sau că tasările s-au produs în acest sens, dintr-un motiv care ne scapă.

Complexul 4. Groapă în C.2, tăiată de complexul 2; a fost identificată de-a lungul profilului (de Est, singurul existent), de o parte şi de cealaltă a complexului 2 ; avea, probabil, o formă elipsoidală foarte alungită sau cvasi-rectangulară. Profilul gropii coboară pe o pantă de $45^{\circ}$, de la $-1,8 \mathrm{~m}$ la $2,15 \mathrm{~m}$. Complexul conţine ceramică (lucrată la roata rapidă, cu coaste în interior, cu pereţi groși, arşi la roşu) şi fragmente de cărămidă, ducând, şi în acest caz (v. comentariile la L.2), că în proximitate au existat clădiri de cărămidă mult înaintea Hanului, adică spre finalul secolului al XVI-lea; nu există indicii clare asupra funcţionalităţii complexului (ar putea fi locuinţă adâncită, datorită deschiderii de trei metri), dar ar putea fi groapă, profilul, atât cât se mai vede, fiind însă relativ atipic pentru ambele situaţii.
Complexul 6 se află în unitatea teritorială C.5, în jumătatea sudică, de-a lungul profilului de $E$, este de formă lunguiaţă, neregulată, pe o lungime de profíl de $2 \mathrm{~m}$. Profilul complexului coboară de la $1,8 \mathrm{~m}$ la $-2,3 \mathrm{~m}$; a fost surprins în secţiune pe o lăţime medie de circa $0,15 \mathrm{~m}$, inventarul fiind puţin şi nesemnificativ. $\mathrm{Nu}$ se poate preciza funcţionalitatea. Complexul face parte din nivelul cel mai vechi de locuire, fiind săpat în pământ virgin.

Complexul 15 se află în C.2, pe mijlocul laturii de $\mathrm{V}$ şi este tăiat de $\mathrm{Z}$. 8 (fundaţia zidului de incintă a hanului). Forma este aproximativ rotundă, cu diametrul de 0,7 m. Stratigrafia gropii nu este pe deplin clară, fînd într-o poziţie fără relaţie stratigrafică (tăiată de fundaţie), dar complexul a fost delimitat la limita solului steril arheologic, la $-1,8 \mathrm{~m}$. Umplutura este tipică pentru o groapă menajeră (oase, ceramică, cenuşă - în această ordine de frecvenţă) şi o atribuim primei etape de locuire.

Complexul 22 se află în C. 8 și este o groapă rotundă, intersectată de profilul estic aproximativ la jumătate, cu o deschidere la profil de $1,16 \mathrm{~m}$ şi un diametru estimat la $1,25 \mathrm{~m}$. Complexul se adânceşte de la $-1,6 \mathrm{~m}$ până la $-2,8 \mathrm{~m}$, cu diametru lărgit la jumătatea înălţimii şi fundul plat. Inventarul gropii este cel obişnuit pentru o groapă menajeră (oase, fragmente ceramice, resturi de materii arse), stratigrafia interioară, marcată de câteva straturi de „cărbune”, mai consistente sau mai discrete, sugerând o umplere rapidă, prin absenţa straturilor de lut de igienizare, prin omogenitatea umpluturii, şi densitatea foarte mică - fapt confirmat de scufundarea pronunţată a primei podele a hanului la verticala gropii (vezi infra). Culoarea, compoziţia şi textura fac umplutura greu de distins de stratul superior din care groapa a fost săpată, relaţie care asigură complexului posterioritatea faţă de L. 3, învecinată la sud. Acest fapt, în schimb, face dificilă aprecierea relaţiei stratigrafice şi cronologice cu L. 4, de la nord. Aparenţa stratigrafică indică un raport de contemporaneitate între cele două complexe, ceea ce, constructiv şi logic este inadmisibil (nimeni nu face o groapă care pleacă exact de la peretele locuinţei). Având în vedere situaţia stratigrafică a L.4, suprapusă 
nemijlocit de prima podea a hanului (v. infra), complexul 22, aici în discuţie, ar trebui să fie anterior locuinţei 4.

Complexul 23 se află tot în C.8, în colţul de NV. Este vorba despre o groapă rotundă, cu diametrul de $1,9 \mathrm{~m}$, cu marginile de $N$ şi $V$ tăiate de $Z .16$ şi Z. 8 . Groapa are profilul uşor lărgit, inventar şi stratigrafie tipice unei gropi menajere, cu numeroase straturi distincte, alternând pământul negru, cu o componentă organică accentuată, cu straturile de cenuşă, lemn ars mărunt şi lut depus, implicând o utilizare ceva mai îndelungată. Groapa a fost surprinsă în plan imediat sub nivelarea de construcţie a hanului, la $-1,35 \mathrm{~m}$ şi coboară până la $-2,8$ m. Complexul face parte din orizontul de locuire care a precedat nemijlocit hanul, găsindu-se, teoretic, pe acelaşi orizont cu L. 4, din camera alăturată, C.7. Din aceleaşi motive expuse la complexul 22 , nu se poate admite o contemporaneitate efectivă cu L.4, ci una relativă.

Complexul 28 se află în C.11, fiind o groapă intersectată de profil, care se adâncește de la $-1,9$ la $-2,9 \mathrm{~m}$. De plan aproximativ rotund, profilul gropii este destul de neregulat, de tip pâlnie, cu fundul rotund şi axul central deplasat spre nord. Conţinutul gropii este cel de deşeu menajer, stratigrafia internă a gropii fiind marcată de câteva straturi de cenuşă, puternic înclinate de la sud la nord. Situaţia se datorează atât conformaţiei dezaxate a gropii, care a produs o tasare similară şi primei podele a hanului (înclinată de la $S$ spre $N$ ) în prelungirea axului gropii, cât şi utilizării exclusiv dinspre sud. Concluzia ar fi că, totuşi, în ciuda evidenţei negative din sectorul săpat pe exteriorul hanului (situaţie descrisă supra), a existat cel puţin o locuinţă şi spre sud, eventual spre $S E$, înainte de începerea înhumărilor.

Este aici de expus o situaţie comună complexelor anterioare hanului: toate se adâncesc într-un sol gălbui, de consistenţă mare, foarte asemănător lutului, dar pigmentat cu fragmente minuscule de lemn ars. Stratul respectiv are o grosime apreciabilă (minim $0,74 \mathrm{~m}$ ). Este posibil ca fragmentele de lemn ars să fie datorate infiltraţiei, odată cu apa de ploaie, în situaţia în care la suprafaţă ar fi avut loc un incendiu de proporţii, urmat imediat de o ploaie substanţială. Ipoteza nu poate fi verificată, partea superioară a acestui strat fiind integral distrusă de gropi, pe toată lungimea de profil a C.11. Indiferent de explicaţie, pigmentul de lemn ars din acest strat atestă o locuire anterioară decât cea documentată de complexele pe care le cunoaştem prin săpătură.

Complexul 31 se află în partea sudică a C. 5 şi este o groapă de formă elipsoidală, cu diametrele de $1,40 \times 0,55 \mathrm{~m}$ (diametrul mare orientat $\mathrm{E}-\mathrm{V}$ ), adâncindu-se în solul steril de la $-1,90 \mathrm{la}-2,40 \mathrm{~m}$. Complexul este alăturat L. 1 şi se află pe acelaşi palier stratigrafic, respectiv pe cel mai vechi nivel de locuire. Forma complexului poate fi redată foarte exact prin noţiunea de "copaie". Inventarul este foarte sărac. Funcţionalitatea nu poate fi precizată.

Complexul 34 se află în colţul de NE al C.10, fiind o groapă intersectată de profil, cu o deschidere, la profil, de $0,6 \mathrm{~m}$ (cu diametrul mai mare), care se adânceşte de la $-2,1 \mathrm{~m}$ la mai mult de $-2,45$ m (săpătură sistată); profil tipic pentru o groapă menajeră. Complexul se arondează primului orizont de locuire.

Complexul 35 se află în partea sudică a C.11, intersectat de profil, care se adânceşte de la $-1,5 \mathrm{~m}$ la sud $(-1,66 \mathrm{~m}$ la nord, cotă de tasare, ca şi podeaua inferioară a hanului, datorită M.1, aflat la verticală) până la $-2,18$ $m$, cu profil superior de tip pâlnie şi cu fundul relativ drept. Groapa are o formă relativ rectangulară, cu deschiderea de $1,05 \mathrm{~m}$ pe N$\mathrm{S}(0,4 \mathrm{~m}$ la bază). Stratigrafic, complexul se află imediat sub nivelarea de fundare a hanului. La nord, complexul 35 taie colţul superior-sudic al M.1. Umplutura s-a fácut cu pământ de culoare brun-cenuşiu, amestecat cu lentile de lut, fiind omogenă, fără stratigrafie internă, fapt care nu e tipic unei gropi menajere. Inventarul sărac, stratigrafia internă şi externă, cât şi forma complexului, ne-au determinat să emitem ipoteza unor deshumări.

Complexul 36 se află în C.10, în zona sudic-centrală, fiind o groapă care se adânceşte de la $-1,95 \mathrm{~m}$ la mai mult de $-2,36$ m (săpătură abandonată), cu o lăţime la profil de $0,46 \mathrm{~m}$, cu profil uşor conic. Dimensiunile sunt prea reduse atât pentru o groapă menajeră, cât şi pentru un mormânt de adult; 
ar putea fi, în schimb, groapa de înhumare a unui copil (cotele complexului sunt asemănătoare cu cele ale M.1). Complexul secţionează umplutura superioară a L.7.

Complexul 37 se află tot în C.10, la extremitatea de sud, tăiată de Z. 20 şi de profil. Groapa avea o deschidere relativ mare (care însă nu poate fi precizată), se adânceşte de la $-1,86$ la $-2,25 \mathrm{~m}$, cu profil alveolat. Conţinutul gropii este practic identic cu cel al stratului superior din care porneşte (pământ negru-cenuşos, cu pigmenţi de cărbune şi de mortar). Funcţionalitatea complexului nu poate fi menţionată.

Complexul 38 se află în extremitatea de SE a C.11, complexul fiind tăiat de Z. 21 la sud şi de complexul 35 la nord. Complexul nu a fost surprins în grund, ci numai în profil, are aceleaşi cote şi condiţii stratigrafice ca groapa alăturată. În consecinţă îi atribuim aceeaşi funcţionalitate ipotetică.

\section{3.f. Stratigrafia Hanului Constantin Vodă}

Construcţia hanului a început, fireşte, prin săparea tranşeelor de fundaţie. Acestea nu erau mai adânci de $0,4-0,5 \mathrm{~m}$, în ceea ce priveşte fundaţiile $\mathrm{E}-\mathrm{V}$, şi ceva mai mult pentru fundaţia zidului de incintă, $\mathrm{N}-\mathrm{S}$, în special în sectorul nordic (v. Pl. XI/1), unde poate ajunge la $1,5 \mathrm{~m}$ (în dreptul camerelor 1-5). Adâncimile acestea sunt relativ mici pentru o clădire care era destinată, probabil de la început, să aibă etaj (v. Pl. III/1). Nu există un algoritm clar al cotelor de fundare, care par rezultatul unei aproximări cu ochiul liber, ca de altfel şi traseele zidurilor interioare (v. Pl. IV $^{17}$ ). Şi mai surprinzător este însă faptul că cotele fundaţiei zidului de incintă sunt ceva mai mici în sectorul sudic, adică acolo unde panta este mai accentuată, iar cerinţe minimale de stabilitate structurală, fie şi la modul cel mai intuitiv, ar fi cerut fundaţii mai adânci.

\footnotetext{
${ }^{17}$ Observând cât de dezordonat arată planul zidurilor după prima măsurătoare, am făcut o a doua măsurătoare a tuturor zidurilor, iar pentru cazurile cele mai flagrante $(Z .11,12,13)$ o a treia măsurătoare. Toate măsurătorile au fost efectuate cu luneta topografică — singura unealtă in posesia Muzeului Naţional, la acel moment-, toleranța maximă posibilă fiind de $0,10 \mathrm{~m}$, dar ea nedepăşind în mod normal $0,05 \mathrm{~m}$, fiindcă măsurătorile repetate duc la reducţia erorilor sistemice de citire.
}

Pământul scos din tranşeele de fundaţie a fost răspândit pe suprafaţa camerelor, ridicând nivelul acestora faţă de exterior, de la început, cu circa $0,15 \mathrm{~m}$ (după tasare!). Acest strat există practic peste tot, un dubiu existând numai pentru C.7, unde, înainte de surparea malului, după străpungerea ultimei podele, de lemn, s-a dat direct peste un animal mare, în poziţie anatomică (aflat, de fapt, în umplutura superioară a unei locuinţe, respectiv L.4). Acest strat este un pământ negru-cenuşiu, cu chirpici mărunt, urme de lemn ars şi cioburi mărunte, şi are acelaşi aspect în toate camerele; deşi greu de distins de straturile peste care a fost aşezat, având aceeaşi culoare şi compoziţie, a fost sesizat peste tot ca o separaţie clară a nivelurilor hanului de nivelele anterioare.

Din şanţurile de fundaţie a fost scos nu numai pământ negru, rezultat al locuirii din secolele anterioare, dar şi lut şi prundiş. Lutul a fost folosit pentru orizontalizarea şi impermeabilizarea podelei; pietrişul a fost însă înlăturat (nu există în strat) sau folosit pentru prepararea mortarului. Aceste paturi de lut nu au peste tot aceeaşi consistenţă, aspect şi grosime, dar există practic peste tot, fie că prima podea a fost de cărămidă sau de lemn.

În ce priveşte podelele, acestea sunt, după câte am observat, numai de două tipuri: de scândură sau de cărămizi legate cu lut. Există o singură excepţie, sub asfaltul trotuarului pe care a fost practicată caseta, la $-0,3 \mathrm{~m}$, fiind descoperite dale de piatră pătrate, prelucrate industrial; acestea însă, aproape sigur, nu aparţin hanului, ci amenajării de exterior de la începutul secolului XX.

Starea de conservare a podelelor este destul de diferită. În ce priveşte podelele de lemn, semne mai evidente au păstrat cele incendiate, acestea fiind însă puţine. Celelalte, prin putrezire, au lăsat straturi infime, brune, friabile, din care urmele de fibră au dispărut aproape complet. În ce priveşte podelele de cărămidă, acestea sunt făcute aproape numai din cărămidă fragmentară, legată cu lut. În multe situaţii, la Camerele 1-7, săpate cu excavatorul, nu s-au mai păstrat, stratigrafic, decât nivelele de lut, în profil rămânând puţine colţuri de cărămidă. Experienţa camerelor săpate arheologic arată însă că lutul era numai un suport pentru alt 
material, fie el lemnul sau cărămida. Chiar și in aceste cazuri, starea de conservare a unor podele era precară, acestea fiind parţial distruse, fie datorită unor lucrări de nivelarereamenajare, fie datorită recuperării parţiale a cărămizilor, în operaţiunile de reparaţii şi reamenajare.

Complexe anterioare hanului locuinţa cu pivniţă, locuinţe-bordei; gropi menajere, toate presupunând deci cavităţiau adus edificiului repetate prejudicii, prin tasare, podelele camerelor scufundându-se la mijloc. Exemplul cel mai radical este C.7, unde nivelurile hanului sunt scufundate, prin tasare, cu până la $0,5 \mathrm{~m}$, în zona centralsudică, acolo unde suprapuneau L.4. Astfel de fenomene se întâlnesc şi în alte spaţii ale hanului, chiar dacă de mai mică amploare. Astfel, la profilul C.8 (v. PI. XIV) se poate observa o alveolare a podelei de cărămidă celei mai vechi în dreptul gropii menajere. La acelaşi profil se mai poate observa ceva, şi anume o uşoară scufundare a celei de a doua podele de cărămidă, la marginea de nord, ceea ce înseamnă că procesul de tasare afecta chiar unele fundaţii, în acest caz a Z.16. Remediul folosit în cazul podelelor se poate observa tot la profilul C.8, şi anume o nouă amenajare de orizontalizare, cu pământ adus. Acest pământ este în general negru, cu pete accidentale de argile de compoziţie diferită, conţinând toate ingredientele unui pământ de umplutură, inclusiv ceramică şi monede din secolele anterioare. Astfel de reamenajări de nivelare există în toate camerele, cel puţin una, dar frecvent două sau trei. Această particularitate a sitului a făcut foarte dificilă prelucrarea inventarului arheologic, luânduse în considerare, pentru diferenţiere, principiul fragmentarităţii (zonele cu fragmentaritate mare sunt un indiciu al materialelor purtate). Consecinţa este că se pot preciza speciile ceramice noi pe nivelele hanului, dar este mult mai dificil de a arăta câtă vreme au mai fost produse speciile ceramice vechi şi în ce proporţii.

După depunerea stratului de nivelare (orizontalizare) se repeta, de obicei, procedura cu amenajarea unui strat compact de lut, peste care se amenaja podeaua propriu-zisă. Dacă reamenajarea podelei se producea în timp scurt, podeaua mai nouă este făcută practic direct peste cea dinainte, fără alte amenajări. Pentru a exemplifica doar, în C.2, la $-115 \mathrm{~cm}$ a fost amenajată $o$ podea de lemn, direct peste o podea de cărămidă, care la rândul său stă pe o altă podea de lemn (v. PI. XIII); cele mai vechi podele din C.7 sunt ambele de lemn, direct suprapuse.

Numărul de podele variază de la cameră la cameră, lucru care ar trebui să aibă cel puţin două cauze. Prima este că, fără îndoială, reamenajările au putut să aibă ca efect, în unele situaţii, distrugerea podelelor anterioare. În mai multe situaţii unele amenajări nu au putut fi surprinse decât într-o parte a camerei, ceea ce nu înseamnă nu au existat pe toată suprafaţa. În alte cazuri au fost găsite numai paturile de lut (sau părţi din acestea) pe care se făcea podeaua, dar nimic din podelele propriuzise. Un caz ilustrativ este cel al podelei de cărămidă din C.10, aflată la -155 . Partea sudică era aproape perfect conservată, pe circa $7 \mathrm{~m}^{2}$, în timp ce din partea nordică fuseseră demontate cărămizile, rămânând numai patul de lut al podelei, destul de consistent (gros de circa $10 \mathrm{~cm}$.)

O a doua explicaţie este de căutat în structura de proprietate sau uzufruct ${ }^{18}$ a spaţiilor hanului. Aşa cum rezultă din planul clădirii realizat la 1848 (PI. II), fiecare din aceste camere avea uşă de acces la stradă. Planul mărturiseşte utilitatea comercială a acestor spaţii. Din punct de vedere administrativ toate camerele erau independente (nu există uși de comunicare laterală, ci numai în adâncime, spre curtea interioară). Având administraţie diferită, nu trebuie să ne aşteptăm la amenajări identice, nici ca număr, nici calitativ. Cele mai vechi podele sunt în general de lemn, iar cele mai noi sunt de cărămidă legată cu lut, dar în unele cazuri ordinea se inversează.

$\mathrm{Nu}$ ar trebui uitate nici efectele tasărilor, inegale datorită structurii diferite a solului de fundare, care au obligat la mai multe refaceri în anumite perimetre decât în altele.

\footnotetext{
${ }^{18}$ Hanul a fost proprietatea lui Vodă Brâncoveanu, iar după moartea acestuia a aparţinut Mănăstirii Văcăreşti, până la demolarea sa. Înstrăinări ale unor părți ale construcţiei s-au fãcut numai pe latura de sud, care nu a fácut obiectul acestor cercetări arheologice. În ciuda structurii de proprietate omogene, evidenta arheologică sugerează că chiriaşii luau în propria mână amenajările interioare.
} 


\section{3.g. Descrierea sumară a stratigrafiei camerelor hanului}

Descrierile de mai jos au menirea de a face $o$ prezentare sinoptică a principalelor nivele de amenajare, descrise de jos în sus, adică de la cele mai vechi spre cele mai noi. Procedurile de amenajare şi reamenajare sunt cele descrise mai sus, motiv pentru care, în majoritatea cazurilor, în sinopsis sunt prezentate numai nivelele certe de amenajare ale podelei. Descrieri mai detaliate sunt făcute numai acolo unde se consideră că sunt semnificative, şi, fireşte, acolo unde stratigrafia este inteligibilă. Cotele sunt date în centimetri, măsurate de la asfalt (pentru o comparaţie mai facilă), straturile înguste fiind notate cu o singură cotă, care este cea inferioară. Descrierea face abstracţie, pe cât posibil, de scufundările de nivel, fiecare nivel fiind măsurat ideal, în partea cea mai puţin afectată de tasări.

CAMERA 1. Podele:

$$
\text { 1. }-130 \mathrm{~cm}: \operatorname{din} \text { lemn }^{19} \text {; }
$$

19 Este unul dintre rarele cazuri în care fragmente minuscule ale podelei de lemn au fost conservate, fiind surprinse în analiza sedimentologică (v. secţiunea 6.c, US 116). Aspectul este confirmat în raportul palinologic, unde US 116 este considerat, de asemenea, podea de lemn. Înregistrarea foarte detaliată a straturilor face ca aici să pară a exista mai multe podele: cea de lemn (US 116), apoi o argilă roşcată, suport al podelei de lemn (US 117 - în ambele rapoarte). Raportul palinologic interpretează US 117 chiar ca o ,succesiune de podele (nivele de călcare)". Problema e că pe şantierele medievale nu prea se întâmplă să vezi patru podele pe doi centimetri înălţime, fiindcă tasarea straturilor este mult mai mică faţă de ceea ce se poate găsi, de exemplu, pe stratigrafia neoliticã. Fie-mi permis să cred că vorbim, aici, despre straturi succesive de argilă din amenajarea aceleiaşi podele, finisată apoi cu scândură de lemn. Un alt fapt interesant este indicat de sedimentolog pentru nivelul ocupaţional al acestei podele (US 115), unde sunt identificate coprolite de ovicaprine, ceea ce înseamnă că, fie şi pentru o perioadă limitată de timp, aici au fost adăpostite animale. Identificarea coprolitelor este repetată pentru un strat superior (US 113), care corespunde tot locuirii realizate pe suportul initial al acestei podele. Apariţia intermitentă a acestui element sugerează un uz sezonier, altemând utilităţi diferite, deoarece coprolitele de ovicaprine şi structura de combustie sunt două elemente care se elimină reciproc, fíndcă animalele nu sunt tinute în spaţii încălzite, nici în proximitatea imediată a unui atelier meşteşugăresc. Desigur, putem admite că cele două întrebuintări distincte $s$-au succedat, la momente diferite, deasupra aceleiaşi podele. Oasele de peşte par a pune o a treia problemã - eventual un al treilea tip de uz.
2. $-105 \mathrm{~cm}$ : posibil podea, probabil lemn ${ }^{20}$;

3. $-100 \mathrm{~cm}$ : probabil cărămidă (două cărămizi în nivel) ${ }^{21}$;

straturile superioare sunt deranjate.

CAMERA 2 beneficiază de 0 situaţie favorizantă, pe care încercăm a o descrie mai detaliat. Partea sa de vest, dinspre zidul de incintă, deşi a fost săpat cu excavatorul, avea o stratigrafie foarte explicită, atât în ce priveşte nivelul de fundare al hanului, cât şi unele detalii privind o perioadă de abandon a clădirii. În plus, Camera 2 a beneficiat de săpătură şi în partea sa estică, în casetă, având acolo un al doilea profil (redat la Pl. XIII), comparaţia permiţând nuanţări. Cele două profile au fost interpretate la distanţe mari în timp, practic independent, observaţiile completându-se fericit. Cotele din casetă au fost reconsiderate, la nivelul căii de rulare (la Pl. XIII, pentru calcularea adâncimilor nu se va lua în considerare „stratul" superior, unde figurează bordura recentă). În cele de mai jos se prezintă o sinteză a celor două profile, evidenţiind podelele certe:

$-130 \ldots-145 \mathrm{~cm}$ : nivelarea primară, cu pământ negru-amestecat;

$-130 \ldots-140 \mathrm{~cm}$ : o insulă de mortar, cu diametrul de $1,30 \mathrm{~m}$, cu profil alveolat, cu adâncimea maximă de $10 \mathrm{~cm}$., suprapune nivelarea (= groapă de preparare a mortarului pentru construcţia hanului); nu apare la Pl. XIII, situaţia descrisă fiind surprinsă numai pe profilul de vest din secţiune;

$-120 \ldots-130 \mathrm{~cm}$ : amenajarea de lut (= patul de amenajare a podelei);

$-120 \mathrm{~cm}$ : podea 1 (lemn) - nu există în desenul de la $\mathrm{Pl}$. XIII, fiind surprinsă numai pe profilul de vest al secţiunii;

$-116 \mathrm{~cm}$ : podea 2 (cărămidă - făcută direct peste prima podea);

$-112 \mathrm{~cm}$ : podea 3 (lemn - făcută direct peste podeaua anterioară);

$-110 \mathrm{~cm}$ : amenajare de lut (,pat”; nu există urme ale unei podele amenajate peste);

$-105 \mathrm{~cm}$ : nivelare cu pământ amestecat;

$-100 \mathrm{~cm}$ : pat de lut (pentru podeaua 4);

\footnotetext{
${ }^{20}$ Echivalent US 110 - vezi secţiunea 6.c.

${ }^{21}$ Echivalent US 109 în analiza sedimentologică (vezi secţiunea 6.c.).
} 
$-90 \mathrm{~cm}$ : podea 4 (cărămizi);

$-80 \ldots-90 \mathrm{~cm}$ : o amenajare de lut (podea?)

între două niveluri subţiri de distrugere;

$-60 \ldots-80 \mathrm{~cm}$ : trei niveluri cu aspect de groapă menajeră (abandon de spaţiu locativ?); o dungă de mortar marchează lucrări de refacere;

$-50 \mathrm{~cm}$ : podea 5 (cărămidă) - aparent fără amenajarea unui pat de lut; conservată parţial (distrusă de amenajările ulterioare); $-45 \mathrm{~cm}$ : patul de lut pentru podeaua următoare;

$-40 \mathrm{~cm}$ : podea 6 (cărămidă);

$-25 \mathrm{~cm}$ : podea 7 (cărămizi întregi $26 / 16 / 5$ $\mathrm{cm}$ şi fragmentare) - surprinsă numai în casetă, nivelul corespondent din stradă fiind distrus de amenajarea căii de rulare; se poate presupune că acest nivel a fost distrus peste tot;

\section{CAMERA 3}

Condiţiile în care a fost săpată camera (cu excavatorul) cât şi faptul că tot centrul camerei este distrus de o groapă imensă, care coboară de sub asfalt, compromit înţelegerea situaţiei stratigrafice de aici.

\section{CAMERA 4. Podele:}

1. $-130 \mathrm{~cm}$ : lemn pe pat de lut (gros de $0,10 \mathrm{~m})^{22}$

2. $-120 \mathrm{~cm}$ : lemn (?), suprapus continuu de un strat de mortar ${ }^{23}$; este vorba despre o amenajare de un tip particular, şi nu de urme ale unor lucrări de reconstrucţie, stratul de mortar fiind continuu, şi nu marginal; situaţia se repetă pe amenajările superioare;

3. $-105 \mathrm{~cm}$ : lemn, nivel incendiat ${ }^{24}$;

\footnotetext{
22 Acest nivel îşi găseşte corespondent numai în secţiunea palinologică (7), identificată drept US 420 (,o succesiune de podele"), care suprapune nemijlocit un "nivel ocupaţional exterior", format deci în aer liber (secţiunea 6.c., US 421), cel care deci alcătuia nivelul de călcare la momentul când se desfăşura construcţia hanului, şi care suprapune un strat siltic de acumulare eoliană (secţiunea 6.c., US 422), sau, mai simplu, un strat de abandon.

${ }^{23} \mathrm{La}$ acest nivel se referă analiza sedimentologică ( $v$. secţiunea 6.c.), respectiv US 418 (,succesiune de podele" in raportul palinologic) şi US 417 (depunerea de locuire corespondentă). Analiza respectivă sugerează un spaţiu cu destinaţie culinară (probabil bucătărie).

${ }^{24}$ La această podea se referă sedimentologul ( $v$. secţiunea 6.c.) prin US 415 şi 414 . Îmi permit să reinterpretez aici datele oferite de specialist, în sensul a două amenajări distincte, la nivel micro, respectiv două secvenţe diferite de amenajare a aceleiaşi podele:
}

4. $-85 \mathrm{~cm}$ : arsură fină, probabil lemn ars (are, deasupra şi dedesubt, câte un strat subţire de mortar); stratul inferior de mortar ar putea indica lucrări de reparaţie; 5. $-65 \mathrm{~cm}$ : podea de lemn (?), suprapusă de un strat de mortar (nu var).

Sub Z. 13 a fost observată amprenta unui ţăruş de tasare (pilot), lung de $62 \mathrm{~cm}$, cu diametrul de $10 \mathrm{~cm}$ în partea superioară şi $8 \mathrm{~cm}$ în partea inferioară, ascuţit în $\mathrm{V}$ pe ultimii $5 \mathrm{~cm}$, înfipt cu o deviaţie de $6^{\circ}$ la verticală; un al doilea ţăruş de tasare a fost observat la intersecţia profílelor de $\mathrm{V}$ și $\mathrm{N}$ ale Camerei 5 , fiind lung de $82 \mathrm{~cm}$, cu diametrul maxim de circa $13 \mathrm{~cm}$; nefiind înfipt complet (ieşea afară, în şanţul de fundaţie, $18 \mathrm{~cm}$ ) a fost prins în zidărie. Astfel de ţăruşi au fost observaţi, mai numeroşi, la Hanul Zlătari ${ }^{25}$.

CAMERA 5. Podele:

1. $-130 \mathrm{~cm}$ : podea lemn, incendiată

2. $-110 \mathrm{~cm}$ : podea lemn, păstrată parţial (spre sud)

podeaua de lut bătut (415), posibil văruit (US 414) din motive sanitare (destinaţia utilitară era de bucătărie), ceea ce explică aspectul de covor de ,mortar" continuu, aşa cum a fost notat pe şantier. C. Haită notează aici, interesant, existenţa unei cuverturi vegetale (rogojină?), care suprapunea amenajarea anterioară. Desigur, această variantă ar putea fi luată în consideraţie şi pentru alte cazuri, în care fibra lemnoasă nu a fost identificată; aşa cum am mai spus, notaţia ,podea de lemn" nu este o constatare fizică, nefiind conservată, cel mai adesea, nici un fel de fibră lemnoasă, ci este doar o extrapolare simplificatoare a constatării absenţei unei podele din materiale de construcţii perene, precum cărămida. Mai aduc aminte, în acest context, că primele camere -inclusiv aceasta, 4 -au fost golite cu excavatorul, singurele observaţii realizate fiind cele prilejuite de curățarea profilelor.

${ }^{25}$ Tăruşi ascuţiţi, bătuţi în pământ la intervale mici, formand o reţea, sunt folosiţi pe terenuri slabe, cu argile şi nisipuri, pentru a creşte densitatea solului, în zone unde sunt necesare construcţii grele, de obicei chiar pe traseul fundaţiilor, înainte de edificarea acestora. Dana Mihai $(2005,275$, nota 19$)$ enumeră câteva din situaţiile în care acest procedeu a fost documentat pentru construcţii medievale din Muntenia, numindu-le impropriu „tiranţi”, apoi, corect, ,piloţi”. Nu este vorba despre vreo invenţie medievală târzie, ci de o tehnică străveche, întâlnită, de exemplu, la incinta elenistică a Histriei, la amenajarea portului de la Păcuiul lui Soare, sau la cetatea lui Ştefan cel Mare de la Roman, toate aşezate pe soluri nisipoase. Vezi, mai recent, Draşovean et alii 2007, 11-84, care atestă utilizarea sistematică a piloţilor sub fundaţie, inclusiv pentru obiective civile cu structură de lemn, în cazul unor soluri foarte umede, cu este cazul Timişoarei. 
CAMERA 6. Nu există desen de profil (zona a fost distrusă înainte de realizarea documentaţiei).

\section{CAMERA 7. Podele:}

1. - $155 \mathrm{~cm}$ : podea de lemn dublă (refăcută la aproape aceeaşi cotă); este scufundată prin tasare până la $-205 \mathrm{~cm}$;

2. $-125 \mathrm{~cm}$ : podea cărămidă;

3. $-117 \mathrm{~cm}$ : podea cărămidă;

4. $-97 \mathrm{~cm}$ : podea lemn (?);

5. $-70 \mathrm{~cm}$ : podea (lut cu cărămidă)? cota se datorează tasării; la nord, nivelul coboară de sub îmbrăcămintea asfaltică $(-45)$;

Notă: cotele podelelor din Camera 7 , în special cele inferioare, sunt afectate de scufundările provocate de Locuinţa 4 , tasarea coborând nivelele cu până la $0,5 \mathrm{~m}$ (pentru zona central-sudică; cotele sunt luate pentru poziţia cea mai înaltă).

CAMERA 8. Podele (v. şi PI. XIV):

1. $-120 \mathrm{~cm}$ : podea de cărămidă;

2. $-90 \mathrm{~cm}$ : podea de cărămidă;

3. $-80 \mathrm{~cm}$ : posibilă podea de lemn (nivel ars, subţire, egal pe toată suprafaţa); patul de lut al podelei însă fie lipseşte, fie este amenajat superficial, din pământ amestecat;

4. $-45 \mathrm{~cm}$ : podea de cărămidă;

5. $-40 \mathrm{~cm}$ : amenajare (,pat”) de lut, care de obicei precede o podea; de aici în sus, însă, începe cămaşa asfaltică a căii de rulare actuale;

CAMERA 9; niveluri scufundate prin tasare (cotele sunt orientative):

1. $-160 \mathrm{~cm}$ : podea cărămidă;

2. $-140 \mathrm{~cm}$ : podea lemn;

3. $-100 \mathrm{~cm}$ : podea cărămidă.

CAMERA 10. Podele:

1. $-145 \mathrm{~cm}$ : podea de cărămizi lipite cu lut, suprapusă de un mic strat de locuire (surprins înspre partea de $\mathrm{N}$ ); deasupra - $\mathrm{o}$ dungă consistentă de mortar (dar tot pe partea de nord); ambele aceste straturi par distruse în zona centrală şi de Sud de nivelarea superioară, care precede următoarea amenajare;

2. $-130 \mathrm{~cm}$ : podea de lut (cu fragmente de cărămizi), suprapusă de un nivel de distrugere (cărămizi căzute --care nu fac parte din podea - şi o dungă de tencuială amestecată cu cenuşă; urmează o nivelare subţire;
3. $-100 \mathrm{~cm}$ : podea de cărămidă, care stă pe o dungă consistentă de mortar (= reconstrucţie); este suprapusă de un strat subţire de locuire, suprapus la rându-i de un nivel masiv de distrugere (incendiu, probabil cel din 1847).

Notă: după acest moment —spaţiul nu a mai fost locuit, fiind transformat, cu destulă certitudine, în depozit de deșeuri menajere şi constructive, alternând straturile negru-cenuşoase (cu deşeuri menajere) cu depunerile de lut (cu scop igienic) sau straturi de incendiu (mai probabil focuri făcute pe loc, cu acelaşi scop de igienizare?), totul amestecat cu materiale de construcţie (moloz, dar nu compact); aceste depuneri au un aspect stratigrafic destul de puţin obişnuit, formând, împreună şi destul de simetric, ceea ce s-ar putea numi un ,gorgan”, sau, pur şi simplu, grămadă de gunoi; forma destul de ţuguiată a acestui "gorgan" sugerează că zidurile erau încă în picioare, iar gunoiul era aruncat de la o înălţime apreciabilă, posibil chiar de la etaj, vârful grămezii (retezat de amenajarea Căii Victoriei) aflându-se undeva la 2 metri de zidurile de la S şi V (respectiv Z.19 şi Z.18); situaţia descrisă nu are corespondent în restul săpăturii; de menţionat că, totuşi, activităţi de (re-)construcţie aveau loc în proximitate, unul dintre straturile grămezii fiind o dungă de mortar (la marginea de sud a camerei, lângă zidul 20$)^{26}$.

CAMERA 11

$-100 \mathrm{~cm}$ : podea cărămidă;

-cel puţin alte 3 amenajări cu lut, cea inferioară la $-160 \mathrm{~cm}$;

Stratigrafia camerei a fost puternic perturbată de câteva gropi târzii.

${ }^{26}$ Dana Mihai $(2005,273)$ remarca următoarele: „În planul Jung din 1856 apare figurat hanul în mod diferit faţă de cel al lui Borroczyn. Interesant de observat este faptul că hanul pare să fie în formă de $L$, respectiv pe laturile de nord şi vest, iar restul clădirilor având să fie adăugate ulterior". Dincolo de faptul că logica domniei sale nu aderă la principiile stratigrafice sau la cronologie (planul lui Borroczyn este anterior), observaţia că la 1856 mai existau doar laturile de nord şi de vest este interesantă şi, posibil, de pus în legătură cu situaţia observată în cercetările arheologice din 1996. În această situaţie, însă, demolarea din anul 1853 a afectat şi o parte a laturii vestice, respectiv tot ce era la sud de Camera 9 (10?). 
CAMERA 12. Nu există profil (nu s-a săpat, locul fiind îngust). ${ }^{27}$

\section{3.h. Amenajări exterioare hanului}

Partea de sud a secţiunii făcute în faţa Muzeului Naţional pentru introducerea conductei este traversată pieziş, de la NNV la SSE, de zidul de incintă, notat aici, după unghiul din dreptul Camerei $8-$ Z.16. Aici a fost practicată o săpătură de cercetare, pe o lungime de şanţ de 5 metri (v. PI. IV), pe exteriorul hanului. Sub asfalt şi îmbrăcămintea asfaltică, între $-0,56$ și $-0,76$ $m$ se găsește un strat care are în amestec pietriş, nisip şi diverse materiale de construcţie (moloz). Între $-0,76$ şi $-1,60 \mathrm{~m}$ se găseşte un pachet de straturi alternând de opt ori, aproape perfect simetric, două tipuri asemănătoare de straturi subţiri, unul fiind un pământ brun-roşcat (cunoscut în literatura arheologică drept „sol de pădure”), iar celălalt un lut galben-roșcat foarte aderent, amestecat în mici proporţii (circa 15\%) cu pământ negricios-brun. În tot acest strat nu se află, practic, material arheologic, cu excepţia unei lentile mici de moloz, înspre nord, la $1,04 \ldots-1,14 \mathrm{~m}$, semnificând un moment problematic în existenţa hanului, de poziţionat, teoretic, la sfârşitul primei treimi de evoluţie, deci în jur de 1750 . Stratigrafia sectorului se completează, de la $-1,60$ la 2,10 $\mathrm{m}$, cu un strat compus din pământ negru, clisos, cu foarte puţine urme antropice (doar câteva urme de cărămidă spartă şi chirpici), şi, între $-2,10 \ldots-2,45 \mathrm{~m}$, un strat asemănător $\mathrm{cu}$ cel superior, diferenta între straturi realizându-se treptat, fiind acelaşi pământ clisos, cu nuanţe gri-verzui la partea inferioară. Acest ultim strat era aparent complet steril arheologic; totuşi, la $-2,30 \mathrm{~m}$ a apărut un ciob smălţuit din secolul al XVIlea, fără a putea fi observată vreo anomalie sau deranjament stratigrafic. Săpătura a fost sistată la $-2,45 m$ datorită apei freatice.

La circa jumătate de metru de aliniamentul zidului de incintă, la adâncimea de $-1,6 \mathrm{~m}$, adică la cota de jos a pachetului de

\footnotetext{
${ }^{27}$ Deşi pe planul de la Pl. IV figurează camerele 11-13, inclusiv zidul de E al camerei 12, acele zone nu au putut fi cercetate. Zidurile aflate sub trotuar au putut fi puse în plan mai târziu, în toamna anului 1996, ca urmare a unei noi intervenţii a constructorilor.
}

soluri roşiatice, a apărut un şir de stâlpi, în linie aproximativ dreaptă şi paralel cu zidul. Bârnele erau foarte bine conservate, în special în partea inferioară (cea care stătea mai mult în apă, după cum am văzut cu pânza freatică), aveau la bază dimensiuni similare (ambele bârne pe care le-am scos şi le-am măsurat aveau diametrul inferior de $26 \mathrm{~cm}$.), fiind separate de spaţii mici (la bază $-10-15 \mathrm{~cm}-$ vezi $\mathrm{Pl}$. V/2). Baza bâmelor era perfect plată, tăiată cu fierăstrăul. Bâmele au fost introduse într-o tranşee cu secţiune în formă de pâlnie, lată la gură de $50 \mathrm{~cm}$ şi adâncă de $90 \mathrm{~cm}^{28}$.

$\mathrm{O}$ situaţie foarte asemănătoare a fost întâlnită în extremitatea nordică a casetei de est, respectiv la exterionul incintei de vest a hanului. Alternanţa straturilor roşiatice era aici mai puţin clară şi simetrică, întâlninduse, între $-0,90 \ldots-1,15 \mathrm{~m}$ şi un material ceramic destul de abundent, de factură târzie, din secolele XVIII-XIX. La $-1,20 \mathrm{~m}$ apărea acelaşi şir de bârne îngropate, orientat paralel cu zidul (aici V-E). Din nefericire, săpătura a trebuit abandonată la $-1,60 \mathrm{~m}$, fără a realiza desene de detaliu, deoarece zona a fost inundată repetat de apele de ploaie scurse din strada Stavropoleos.

Interpretarea situaţiilor întâlnite la exteriorul hanului a dat loc la destule discuţii contradictorii în cadrul colectivului (şi chiar în afara acestuia). În fine, s-a convenit asupra mai multor elemente.

Straturile inferioare din sectorul exterior de sud, de culoare negru-cenuşiu, dense, umede, datorează lipsa aproape completă a materialului arheologic faptului că zona nu a fost locuită, fiind rezervată unei necropole (probabil de mici dimensiuni).

Este clar că bârnele au fost îngropate în pământ după construcţia hanului, fiindcă aliniamentul lor urmează, aproximativ paralel, aliniamentul fundaţiei, iar pe nivelul superior al bârnelor nu exista nici un indiciu de activităţi constructive (de ex. fragmente de mortar). Foarte probabil aliniamentul de bâme nu este mult posterior construcţiei hanului, în sprijinul acestei afirmaţii venind în primul rând cota superioară de îngropare,

\footnotetext{
${ }^{28}$ Adâncimea tranşeului a fost măsurată indirect (fundul tranşeului era sub apă), măsurând lungimea celor două bâme scoase în acest scop.
} 
de $-1,60 \mathrm{~m}$, care este cea de la care s-au săpat fundaţiile hanului.

Este la fel de clar că acest tip de amenajare nu are nici o legătură cu consolidarea terenului prin baterea unor ţăruşi ascuţiţi (diferenţele sunt prea evidente pentru a le explica). Mai mult decât atât, tranşeul în care au fost introduse bârnele putea, cel mult, să afecteze stabilitatea fundaţiei, motiv pentru care a şi fost săpat la oarecare distanţă (aproximativ 0,50 m).

Interpretarea straturilor succesive de pământ/lut roşiatic este ceva mai dificilă. Să spunem deocamdată că ,pământul roșu de pădure" nu este adus din pădure, pentru că, până la proba contrarie, nu se poate găsi nici o motivaţie unui asemenea efort, iar culoarea roşie a lutului este o curiozitate care, în acest caz, se poate pune pe seama contaminării. Nefiind adus, putem presupune doar că acest sol roşu este format pe loc, prin degradarea unei mari mase de lemne. Problema este că nu am putut surprinde nici cea mai mică rămășiță de fibră lemnoasă, ceea ce, prin comparaţie cu podelele de lemn ale hanului, contemporane, este mai greu de explicat, chiar dacă ne gândim la esenţe lemnoase diferite. $\mathrm{Au}$ fost luate probe sedimentologice din aceste straturi, analizele de acest fel sunt însă foarte laborioase, fiind publicate în secţiunea dedicată sedimentologiei (infra).

Fără a avea certitudine, ne explicăm situaţia stratigrafică din sectoarele exterioare hanului după următorul scenariu: după îngroparea stâlpilor în tranşee, suprafaţa viitorului drum a fost nivelată, a fost depus un strat de lut de maxim $10 \mathrm{~cm}$, peste care s-au aşezat scânduri lungi de 4-5 metri, transversal. Se presupune, fireşte, că o instalaţie similară exista pe partea cealaltă a drumului. Scândurile transversale stăteau deci „punte”, sprijinite la ambele capete pe piloni de lemn ${ }^{29}$. Așa pare să

\footnotetext{
${ }^{29}$ Scenariul imaginat de noi în anul 1996 a fost confimat de săpăturile ulterioare de la Timișoara (Draşovean et alii 2007, în special p. 41); starea de conservare a vechilor amenajări este mult mai bună, tinând cont de solul mlăştinos al oraşului de pe Bega, ceea ce face ca multe detalii ale acestui sistem de construcţie a străzilor urbane să fie acum mult mai clare, de exemplu faptul că, între cele două puncte de sprijin laterale ale „podului”, exista unul suplimentar, pe mijlocul străzii. Drept criteriu indirect al stării de conservare, să consemnăm doar că colegii bănăţeni au recuperat zeci de fragmente de artefacte din piele (idem,
}

se fi născut „Podul Mogoşoaiei”. Această instalaţie a rezistat utilizării cam un sfert de veac, după care a fost depus un alt strat de lut (poate fi, la limită, „glod" scurs de pe drum) şi alt rând de scânduri, operaţia repetându-se, în timp, de 7 or $^{30}$. Scândurile nu erau fixate în cuie $^{31}$ (amenajările superioare nu erau sprijinite direct pe buştenii verticali), ci în acel lut foarte adeziv, care mai avea şi rolul de a impermeabiliza drumul. După cum am mai văzut, lutul era în epocă un liant foarte întrebuinf̧at.

Această ipoteză explică rostul şi forma buştenilor îngropaţi, care erau retezaţi şi nu ascuţiţi, tocmai pentru a împiedica scufundarea. Solul pe care s-a fãcut amenajarea devine cu uşurinţă patinoar, de la primii stropi de ploaie, dar este extrem de dens, fiind dificil de înfipt în pământ până şi fierul cazmalei; un buştean cu diametrul de $26 \mathrm{de} \mathrm{cm}$ nu poate fi scufundat în pământ doar de sarcinile de trafic din secolele trecute, instalaţia fiind încă în bună stare, în fapt, asigurând Căii Victoriei o fundaţie adecvată.

Sistemul acesta de construcţie a drumurilor în zonele mlăştinoase era cunoscut şi folosit încă din epocă romană ${ }^{32}$, fiind utilizat şi în evul mediư ${ }^{33}$.

161-220), care la Bucureşti pur şi simplu nu există. Mulţumiri colegei Daniela Tănase de la Muzeul Banatului, care ne-a facilitat accesul la informaţie.

30 Cercetările din centrul Timişoarei au surprins, similar, şase niveluri distincte de amenajare a străzii (Draşovean et alii, 11-84, în special p. 32)

3 ' Constatare noastră era, simplu, absenţa piroanelor de fier, însă am neglijat posibilitatea cuielor (penelor) de lemn, care intră prin forțare şi se dilată la umezeală, fiind mult mai utile decât cele de fier. Săpăturile colegilor de pe Bega au demonstrat că era vorba despre cuie de lemn (Draşovean et alii 2007, în multiple locuri, de ex. p. 35, fig. 24). Este un alt criteriu de comparaţie a stării de conservare a amenajării: noi nu am găsit nici măcar fragmente de scândură, ei au găsit până şi cuiele de lemn cu care scândurile erau prinse. Foarte adevărat, în cercetările recente din centrul capitalei (2011), am văzut numeroase scânduri fragmentare.

32 „Drumurile cu pat artificial aveau o structură complexă... Straturile inferioare, uneori altemate, erau constituite din pământ, argilă, nisip care ofereau şi o supraînălţare... În regiunile inundabile sau mlăştinoase, substrucţia drumurilor era adaptată condiţiilor fie prin realizarea unui rambleu, fie prin așezarea de fascine sau chiar radiere de bârne pe piloţi" (Enciclopedia Civilizaţiei Romane, București, 1982, s.v. drumurile). Fără a fi identic, sistemul descris este asemănător.

${ }^{33}$ Draşovean et alii 2007, cu referire la lucrăni de salvare din Timişoara, la un palier cronologic similar 
O problemă care ar putea fi ridicată, totuşi, este observaţia că decroşul de fundaţie se află $0,6 \mathrm{~m}$. deasupra primei amenajări a Podului Mogoşoaiei, respectiv la $-0,90 \mathrm{~m}$. faţă de asfalt. Este de remarcat că, în general, decroşul plintei, acolo unde există, se află mult deasupra primei amenajări a hanului şi la interior. Astfel, aceste diferenţe sunt: la C. $1=0,81 \mathrm{~m} ;$ C. $2=0,61 \mathrm{~m} ; \mathrm{C} .8=0,55 \mathrm{~m} ; \mathrm{C}$. $10=1 \mathrm{~m} ; \mathrm{C} .11=1,23 \mathrm{~m}(!)$. (v. Pl. XI/2). Fundaţia clădirii era deci înaltă, depăşind cel puţin cu 0,6 m nivelul de călcare al epocii. Aceste diferenţe mari se pot imputa, însă doar parţial, efectului tasării; tot ele ar putea fi cauza marilor diferenţe; este însă neîndoielnic faptul că plinta se ridica elegant —şi probabil relativ uniform - deasupra solului, oferind o protecţie suplimentară în acel mediu foarte umed.

O chestiune încă şi mai curioasă este că, deşi planul de la 1848 (PI. II) arată intrări dinspre stradă ${ }^{34}$, acestea nu au fost surprinse nicăieri, deşi zidul de incintă era bine conservat, la o cotă mult superioară față de prima podea. De exemplu, în Camera 9 cota conservată a zidului de incintă este mai mare cu 1,2 m. faţă de nivelul podelei celei mai vechi. $\mathrm{Nu}$ avem motive să ne îndoim că aceste intrări existau. Desenul de la 1854 (PI. III), fără a confirma în detalii planul din 1848 (PI. II), confirmă existenta intrărilor de la stradă, cel puţin pentru colţul de SV al cvartalului. Nu ne rămâne decât să presupunem că aceste intrări erau mai sus cu cel puţin $1,20 \mathrm{~m}$, atât faţă de interior, cât şi faţă de exterior, iar accesul se făcea pe scări de lemn (care nu figurează în plan, unde sunt arătate numai scările de acces între palierele clădirii) ${ }^{35}$. O probă arheologică irefutabilă că aşa stăteau lucrurile - nu există, cu excepţia unor observaţii făcute în C.8. Ştim însă, din săpătură, că zona era vulnerabilă la inundaţii, şi acesta ni se pare un motiv suficient pentru a recurge la $o$

descoperirilor noastre. La Timişoara, pentru amenajările timpurii, a putut fi surprinsă inclusiv utilizarea fascinelor (mănunchiuri de nuiele, idem, p. 4l).

${ }^{34} \mathrm{Cu}$ excepţia Camerei 2 , deşi ar putea fi vorba despre o zidire ulterioară a intrării.

${ }^{35}$ La 1848 diferenta de nivel dintre stradă şi intrare trebuie sá fí scăzut, datorită reamenajărilor succesive ale ,podului”, cu $0,6-0,7 \mathrm{~m}$, rămânând la neimpozanta înălţime de două trepte. Un lucru similar l-ar fi produs şi repetatele refaceri ale interiorului. De altfel, aproape sigur acele intrări din stradă nu fac parte din planul iniţial, fiind adaptări comerciale de sec. XIX. asemenea soluţie arhitectonică, cu fundaţii înalte și uşi mult deasupra solului umed.

Într-o singură situaţie am fi putut confirma această teorie prin săpătură, găsind una din uşile de acces de la încăperea dinspre stradă la încăperea dinspre curtea interioară (v. Pl. II). Acest lucru a fost într-o oarecare măsură realizat, dacă privim partea plină a paharului. Conjuncturile nu au fost însă nici aici prea favorabile. Şansa se ivea, desigur, în caseta deschisă pe trotuar (v. Pl. IV). La momentul deschiderii casetei nu beneficiam încă de planul realizat clădirii în 1848 . Oricum, dorința noastră ar fi fost de a decoperta toată suprafaţa corespondentă Camerelor 1 şi 2 din secţiune. Acest lucru nu a fost posibil întru totul, datorită unui...semn de circulaţie. Nedorind să mai avem de a face cu reprezentanţii Poliţiei şi Primăriei (care ne mai atenţionaseră în legătură cu varii aspecte), caseta a fost deschisă numai până la limita de nord a obiectului intangibil, astfel încât zidul 11 şi extremitatea sudică a Camerei 2 aveau să rămână în afara săpăturii. Comparând acum cele două planuri, vedem că acolo unde ar fi trebuit să găsim ușa între Camera 1 şi camera corespondentă $\left(\begin{array}{ll}C .1 & \text { a }\end{array}\right)$ dinspre interior, adică la $4 \mathrm{~m}$ de colţul de NE al camerei - se găseşte singurul tronson de zid (Z. 24) la cota obişnuită, imediat sub asfalt, scăpat ca prin minune de intervenţiile de secol XX care au răvăşit împrejurimile. În ce priveşte trecerea dintre camerele 2 şi 2 a, care ar fi trebuit să fie la 2,5 m de colţul de NE găsim un alt zid, la aceeași cotă obişnuită.

Care este însă credibilitatea planului de la 1848, dincolo de faptul că numărul de camere ar putea să fie corect? $O$ privire fugară pe planşa IV/3 ne arată că diferenţele sunt foarte mari, rata de eroare a topografilor de la jumătatea secolului trecut fiind mai mare decât cea anticipată, eroarea de desen de la Camera 12 fiind la limita grotescului. Luând în considerare camerele 1 şi 2, constatăm că nu numai cifrele absolute sunt altele, ceea ce nu este de mirare, dar chiar proporţiile sunt diferite. Făcând abstracţie de faptul real că planul camerelor este uşor neregulat, pe planul vechi dimensiunile Camerei 1 sunt 5,8 m (pe axa $\mathrm{N}-\mathrm{S}$ ) şi $4,6 \mathrm{~m}$ (pe E-V), faţă de dimensiunile reale de $4,3 \mathrm{~m}$ şi $5,3 \mathrm{~m}$; latura mai lungă a camerei se află deci pe celălalt ax. În ce priveşte Camera 2 , 
dimensiunile în vechiul plan sunt, în aceeaşi ordine, $4,7 \mathrm{~m}$ şi $4,9 \mathrm{~m}$ faţă de $4,8 \mathrm{~m}$ şi $5,2 \mathrm{~m}$ real; raporturile sunt aici însă mai apropiate.

Nimic nu ne împiedică să presupunem că şi plasamentul uşilor pe plan este tot atât de neglijent. Mai mult, observăm că, de regulă, uşa de acces dintre camera de la stradă și camera dinspre curte, pe toată această aripă de clădire, de la Camera 3 la Camera 7 , se află lângă colţul de SE (v. Pl. II). Dacă uşile s-ar afla cam în acelaşi loc şi în Camerele 1 şi 2, înseamnă că săpătura a surprins totuşi elemente ale acestei realităţi. Ambele colţuri de SE ale acestor camere au suferit stricăciuni de pe urma intervenţiilor mai recente. Intersecţia Z. 10 cu Z. 23 este complet distrusă de un canal, iar în colţul de SE al Camerei 1 se află o gură de canal. Zidul 24, care limitează la E Camera 1 era distrus la capătul de $\mathrm{N}$ de mai multe intervenţii succesive. Spre S, acelaşi zid se oprea inaintea canalului, aşa cum atestă desenele de şantier; faptul a fost pus, atunci, pe seama distrugerii zidului. Situaţia din sud-estul C.2 este foarte asemănătoare. Colţul camerei este străpuns de o groapă de formă neregulată, mai adâncă decât săpătura noastră, umplută, din motive misterioase, cu beton. Şi aici, zidul (Z. 23) se întrerupe, fapt care, şi acesta, a fost pus pe seama intervenţiei recente. Reanalizând desenele, am ajuns la concluzia că zidul nu se întrerupe din cauza gropii betonate, care nu afectează toată grosimea zidului, fiind, aproape sigur, uşa lipsă. Interpretând astfel lucrurile, cele două uşi s-ar afla la locul lor, într-o poziţie perfect asemănătoare cu cele arătate pe planul vechi la camerele 3-7. Lucrurile s-ar fi putut lămuri încă de pe şantier, dacă am fi putut săpa mai adânc pe latura de $E$ a casetei, însă locul strâmt, de nici jumătate de metru, ne-a determinat să oprim săpătura la $-1,1 \mathrm{~m}$, iar la vest de Z. 23 şi Z. 24 situaţia era complet compromisă.

\section{3.h. Paliere cronologice majore}

Pentru prelucrarea materialului arheologic recuperat din săpătură, acesta a fost grupat, funcţie de unitatea stratigrafică de origine, în cinci paliere cronologice, numerotate de la 1 la 5 , în ordine cronologică descrescătoare, respectiv în ordinea cercetării lor. Palierul I grupează complexele care aparţin unei epoci ulterioare demolării hanului (circa 1860). Acestea sunt, în esenţă, câteva gropi cu moloz, stratul de moloz care se găseşte imediat sub îmbrăcămintea asfaltică a căii de rulare actuale şi sub trotuar, tranşeele realizate la începutul secolului XX pentru lucrări de aducţiune şi canalizare, dar şi intervenţii mult mai recente, una dintre gropi conţinând o monedă din anul 1966, pierdută probabil în anul 1970 , cu prilejul lucrărilor de amenajare pentru inaugurarea Muzeului Naţional de Istorie. Majoritatea acestor complexe nu fac decât să întoarcă materialul arheologic mai vechi, existând puţine obiecte care sunt cu certitudine mai noi de 1860.

Palierele cronologice 2 şi 3 sunt cele ale nivelelor de funcţionare ale Hanului Constantin Vodă. Neexistând o corespondenţă absolută între stratigrafia diverselor camere, cu excepţia nivelului de fundare, reamenajările spaţiilor producânduse similar, dar independent, delimitarea palierului 2 de palierul 3 este problematică şi în bună măsură arbitrară. În practică, s-a împărţit înălţimea straturilor corespondente utilizării hanului în două părţi relativ egale, corespunzând, teoretic, secolelor XVIII, respectiv XIX. Intenţia era de a evidenţia diferenţele de material; aşa cum am arătat deja, numeroasele nivelări au făcut această sarcină extrem de dificilă $\breve{~}^{36}$.

Palierele cronologice 4 și 5 au fost rezervate locuirii care a premers construcţiei hanului. Aici diferentele s-au făcut ceva mai uşor, considerându-se pe palierul 5 numai acele complexe care stau direct pe pământ virgin şi nu suprapun stratigrafic nici un alt complex.

Ilustrarea împărţirii stratigrafice pe 5 paliere majore este exemplificată la PI. XIV, pe profilul stratigrafic al Camerei $8 .^{37}$

\section{3.i. Elemente de datare}

Alături de elementele de datare relativă, reieşite din analiza materialului arheologic, care fac obiectul unei secţiuni

\footnotetext{
${ }^{36}$ Aşa cum se va arăta pe larg în secţiunea urmātoare a raportului, dedicatã studiului ceramicii.

${ }^{37}$ Împărţirea complicatei evidenţe stratigrafice în cinci mari paliere a fost necesară pentru a oferi o bazà statistică mai inteligibilă prelucrănii materialelor recoltate, aşa cum, de pildă. s-a întâmplat cu prelucrarea materialului paleo-faunistic (Bălāșescu et alii 2002).
} 
distincte a raportului (secţiunea următoare, 4), există un material numismatic relativ bogat pentru un şantier de salvare, a cărui determinare o datorăm colegului Emest Oberländer-Târnoveanu (secţiunea 5 a raportului). Fiindcă analiza pieselor s-a făcut după ce rândurile de mai sus erau redactate, ne permitem aici niște scurte consideraţii.

$O$ primă constatare este că, din 16 piese numismatice aflate în lot, 13 provin din casetă şi din Camera 8, care, aşa cum spuneam, au făcut obiectul unei cercetări mai atente. Constatarea nu este de natură să surprindă, dar subliniază necesitatea ca, pe un şantier de salvare, în ciuda tempo-ului de lucru impus de termenii de execuţie, să existe spaţii rezervate unei cercetări realizate cu mijloace cât mai apropiate de cercetarea sistematică.

O a doua observaţie este aceea că, rezultat al nivelărilor succesive de reamenajare, asupra cărora am insistat deja, 5 monede provin din poziţii secundare, respectiv monede de secolele XVI-XVII găsite pe nivelele hanului (piesele cu număr de şantier $13,51,52,54,55)$.

O a treia observaţie este aceea că relativ multe piese sunt fragmentare, neputând furniza o datare propriu-zisă; este vorba despre monede care, foarte probabil, au fost bătute în secolele XVI-XVII; nu întâmplător sunt aproape aceleași din lista de mai sus (respectiv 51, 55, 57), starea lor datorându-se nu atât grabei lucrătorilor noștri, cât, evident, faptului că au suferit şocuri mecanice cu prilejul nivelărilor.

Si mai interesant este raportul dintre monedele din secolul al XVI-lea, respectiv al XVII-lea, databile cu certitudine. Este vorba de 4 monede din secolul al XVI-lea (numerele 13, 14, 41, 52) şi numai una din secolul al XVII-lea (nr. 54), şi aceea din poziţie secundară. Credem că acest fapt confirmă de o manieră indiscutabilă opinia exprimată anterior, în baze pur stratigrafice, că în secolul al XVII-lea zona a fost părăsită, în sensul că nu mai era nemijlocit locuită.

Puţine piese dau informaţii utilizabile de cronologie absolută. Dacă moneda găsită pe podeaua L. 3 , în unitatea teritorială C. 8 , la $-3,05 \mathrm{~m}, \mathrm{~s}-\mathrm{a}$ dovedit a fi, spre dezamăgirea noastră, neutilizabilă, în schimb cele două monede din groapa alăturată (complexul 22, v. Pl. XIV coroborată cu Pl. IV) au fost descifrate. Este vorba despre un schilling de la Albrecht I al Prusiei, din anul 1558, şi un dinar de la Ferdinand I al Ungariei, din anul 1551. Cele două monede, având datări atât de apropiate, se confirmă reciproc şi aşează complexul în jur de 1560 , sau imediat după. Având în vedere relaţiile stratigrafice (v. Pl. XIV), faptul că nivelul din care este săpat complexul 22 suprapune umpluturile succesive ale L.3, în fine, faptul, expus supra, că umplerea gropii L3 pare să se fi realizat într-un timp relativ de îndelungat, apreciem că locuinţa în discuţie a funcţionat probabil înainte de jumătatea secolului al XVI-lea. Luând în considerare faptul că şi în L. 3 , şi pe primul nivel al L.2 s-au identificat straturi de nisip asemănătoare, indicând cu destulă probabilitate o inundaţie severă (suntem aici la o cotă de minim $10 \mathrm{~m}$ deasupra Dâmboviţei!), L.2 primeşte aceeaşi datare, pentru primul nivel, şi o datare la mijlocul secolului pentru al doilea nivel de locuire, pentru care există şi material ceramic. În această situaţie, L.1, suprapusă de L.2, se datează la sfârşitul secolului al XV-lea sau la începutul secolului al XVI-lea.

$O$ altă indicaţie preţioasă furnizată de analiza numismatică se referă la perioada finală a hanului. Este vorba despre o monedă de la Ferdinand I, bătută la Viena în anul 1835, găsită în casetă, în Camera 2, pe podeaua 5 (sau în amenajarea pentru podeaua 6, foarte apropiată, vezi Planșa XIII). Imediat deasupra a fost găsită o altă piesă, cu o datare ceva mai largă. Este vorba despre un capac de la un produs cosmetic, purtând marca unui furmizor al reginei Isabella a Spaniei (18331868), găsit în nivelul de amenajare al podelei 7 (cea mai recentă) ${ }^{38}$. Aşa cum am arătat când am expus succesiunea stratigrafică a camerelor hanului, podeaua 5 a

\footnotetext{
${ }^{38}$ Deşi principalele paliere cronologice (v. supra) au fost numerotate de sus în jos, podelele hanului au fost numerotate de jos în sus. Ambele decizii au bune motive: situaţia de ,şantier de salvare" nu ne garanta că vom putea săpa până „la viu”, ceea ce s-a şi întâmplat în câteva ocazii, aşa că numerotarea palierelor de sus în jos făcea sens; în ceea ce priveşte amenajarea podelelor hanului, ele nu puteau fi studiate şi clasate înainte de a finaliza profilul, cel puţin pe primii doi metri; foarte adesea nivelurile superioare erau distruse, din diverse motive, aşa că nomerotarea de jos în sus era obligatoric. Am încercat să reprezentăm corespondenţa dintre aceste podele în tabelul de la $\mathbf{P l}$. XI/2.
} 
camerei 2 suprapune un nivel de abandon. Este posibil să fie vorba despre consecinţele incendiului din 1847 (vezi secţiunea a doua a raportului, referitoare la istoricul hanului). Moneda de la Ferdinand, perforată, deci purtată mai multă vreme, ar putea să fi fost pierdută cândva după anul 1847. În ciuda stării jalnice în care se găsea clădirea, după cum spun documentele epocii, ${ }^{39}$ este destul de sigur că acest spaţiu, cel puţin, a fost folosit intens aproximativ între anii 1850 şi 1860 , podeaua fiind reamenajată de trei ori. Mai mult decât atât, materialele arheologice, respectiv fragmentele de la ceramica de lux, capacul de la produse cosmetice, cât şi rondela pentru bijuterii, găsită pe podeaua 7 (v. secţiunea 5 a raportului), sugerează un magazin cu oarecari pretenţii.

Şi o curiozitate pentru istoricii preocupaţi de viaţa economică: nu a fost identificată nici o monedă otomană. Foarte adevărat, există piese ceramice care atestă însă legături cu sudul.

\section{3.j. Cercetări în 1997}

Ultimele cercetări în stradă s-au făcut în toamna anului 1996, când constructorul a practicat nişte gropi necesare unor racorduri, pe trotuarul din faţa Muzeului Naţional, în dreptul camerelor $10-13$, ceea ce a permis completarea situaţiei de plan, aşa cum se poate constata la PI. IV. După acest moment lucrările constructorilor au fost finalizate. $\mathrm{O}$ neaşteptată ocazie de a rămâne la subiectul Hanului Constantin Vodă s-a ivit anul următor. Se făceau lucrări de reamenajare în depozitul arheologic pentru evul mediu, când s-a constatat că pardoseala de ciment a cedat pe nişte aliniamente mergând paralel şi imediat lângă pereţii de nord şi vest, pereţi lungi de $10,4 \mathrm{~m}$, respectiv $9,65 \mathrm{~m}$. Încăperea se află exact în ,turnul" de sud-vest al clădirii, sub „buzunarul de pe Francezā”, loc obişnuit de amenajare a unor expoziţii temporare; dat fiind că amprenta la sol a clădirii actuale este figurată la Pl. II (cu gris), poziţia încăperii poate fi destul de exact înţeleasă, ţinând cont că pereţii exteriori au cca 1,30 m grosime.

De-a lungul pereţilor de nord şi vest a depozitului podeaua stricată a fost înlăturată,

\footnotetext{
${ }^{39}$ Vezi sectiunea a doua a raportului.
}

arheologii constatând că se aflau în fata unor fundaţii de lemn, groase de cca 30 de cm, intersectate, la intervale mai mari, de stâlpi verticali (mai adânci decât talpa fundaţiei, deci aproape sigur mărturia unor faze anterioare). Fiindcă o săpătură propriu-zisă nu a fost agreată, a trebuit să ne mulţumim cu aceste constatări, cu câteva fragmente ceramice atipice şi cu nişte bucăţi de lemn, parte a tălpilor de fundaţie care încă nu putreziseră.

Ar fi dificil de estimat, cu precizie, corespondenta la planul Borroczyn, pentru că, aşa cum deja am văzut, săpăturile au demonstrat că este foarte aproximativ; oricum, traseul celor doi pereţi de lemn nu corespunde deloc planului de la 1848, aşa că nu putem face altă presupunere decât că ei reprezintă un stadiu mai vechi, al unor construcţii care la 1848 nu mai existau. Cota exactă a podelei din subsol, faţă de trotuar, este de cca. $-250 \mathrm{~cm}$. Comparând acest lucru cu cota de fundaţie a zidului celui mai sudic cunoscut din săpătură $(Z .10,-219 \mathrm{~cm}, \mathrm{v}$. Pl. XI/1, corelând cota fundaţiei și a asfaltului), respectiv $-219 \mathrm{~cm}$, constatăm că suntem, în depozitul muzeului, sub cota de fundaţie a Hanului. Ceea ce am găsit noi este parte a unei clădiri de lemn, suficient de mare pentru a testa faptul că nu este un tip constructiv obişnuit evului mediu (în care o latură poate fi lungă de până la $8-9 \mathrm{~m}$, dar a doua nu este mai lungă de 5-6 m), ci mai degrabă o fundaţie de epocă modernă, foarte adâncă, deci probabil pentru o clădire cu etaj. Asemenea caracteristici ne fac să presupunem că este foarte puţin probabil ca această clădire să fie mai veche de secolul al XVIII-lea și că, oricum, precede forma pusă în plan de Borroczyn. Aceasta ar mai însemna că tot corpul de clădire de pe colţul de $\mathrm{SV}$ al cvartalului pe care a funcţionat Hanul Constantin Vodă era alcătuit din clădiri de lemn şi, foarte probabil, nici nu au aparţinut hanului, ci unor particulari care au profitat de locul lăsat viran spre Ulița Franceză.

Privind înapoi, pe planul de la Pl. II, observăm că această zonă are coloraţie distinctă faţă de principalele corpuri de clădire (coloraţie care respectă diferenţele din original). Multă vreme ne-am întrebat de ce; se pare că acum avem un răspuns: erau clădiri de altă factură. Acest grup de edificii este 
bine individualizat pe reconstituirea propusă la pl. III/1, aparent imediat la sud de „camera" 10 (a se corela cu Pl. II). Ne aducem aminte, acum, că analiza stratigrafică a camerei 10 a ilustrat părăsirea acestei încăperi încă dintr-o etapă timpurie, locul devenind un soi de groapă de gunoi, deşeurile fiind probabil aruncate de la etaj. Surpriză, însă: pe ilustraţia de la 1854 geamurile de la etaj corespondente spaţiului numit de noi, convenţional, camera 10 , existau. Putem formula atunci o ipoteză destul de şocantă: nu acoperişul cedase acolo, ci tavanul parterului din spaţiul numit „camera 10”. La etaj exista, deci, o gaură mare, prin care se arunca gunoiul la parter, ceea ce ar explica forma neobişnuită a ,gorganului" cu moţ... Un „inside" insolit al Bucureştiului de la mijlocul veacului al XIX-lea...

\section{CERAMICA DE LA HANUL CONSTANTIN VODĂ}

\section{Anca PĂUNESCU}

Materialul ceramic rezultat din cercetările arheologice de salvare întreprinse la Hanul Constantin Vodă se prezintă în stare fragmentară şi este destul de amestecat din punct de vedere stratigrafic. Din mulţimea fragmentelor recoltate se pot reconstitui oarecum formele caracteristice predominante ale ceramicii de uz, nesmălţuită şi ale ceramicii smălţuite şi ornamentale şi se pot face unele aprecieri cu privire la evoluţia unor forme, a tehnicilor de decorare şi modelare, pe parcursul secolelor XV-XVIII, chiar până în primul sfert al secolului al XIXlea. Alături de fragmentele ceramicii locale, dar într-o proporție mai mică, s-au descoperit atât fragmente mărunte ce provin de la diverse forme de vase de porţelan sau faianţă orientală (turcească sau persană) realizată în marile centre din Iznik, Cutahia, Damasc, Constantinopol sau produse ale manufacturilor de ceramică renumite din secolele XVII-XIX, în Europa.

De la început trebuie să precizăm că întregul repertoriu al formelor îşi găseşte corespondenţa în formele ceramicii descoperite şi în alte puncte, cercetate arheologic, de pe raza oraşului Bucureşti, fie în apropierea hanului, în punctele Curtea Veche, Biserica Sf. Dumitru Poştă, Piaţa de flori, Mihai Vodă sau în puncte mai depărtate, la Mânăstirea Văcăreşti, Biserica Radu Vodă, Foişorul Mavrocordaţilor sau Biserica Visarion (Cantea 1959, 126-127, 157-160; Panait 1963, 259, fig. 17/1-5; Tico 1981, 242, 246, 267-268, 290).

Caracteristicile generale comune ale ceramicii probează existenţa unor centre de olărie adaptate nevoilor oraşului, şi care prezintă unele aspecte proprii ce deosebesc produsele lor de produsele olarilor din alte oraşe ale Tării Româneşti, cum ar fi Târgovişte, Piteşti, Ploieşti, Craiova, Oraşul de Floci s.a.

În mod curent se obișnuiește ca prezentarea formelor ceramice să fie împărţită în doua mari categorii: ceramică de uz comun nesmălţuită şi ceramică smălţuită, în care se includ şi formele ceramice cu funcţionalitate ornamentală. În prezentarea noastră vom arăta că unele forme ale ceramicii de uz comun se păstrează pe o lungă perioadă, iar decorul realizat prin incizie sau cu angobă albă va fî înlocuit cu smalţ de diferite culori.

\subsection{REPERTORIU FORMELOR}

Ceramica de uz comun este în general lucrată din pastă fină, nisipoasă, mai rar amestecată cu pietricele mărunte, cu pulbere de mică. În urma arderii pereţii vaselor au căpătat culoarea roşu-cărămiziu sau roşucafeniu. Arderea este în general oxidantă, dar multe fragmente au fie miezul cenuşiu, fie suprafał̧a interioară cenuşie, în cazul vaselor de dimensiuni mai mari, la care pereţii sunt mai groşi. De asemenea, la majoritatea fragmentelor se păstrează urme de ardere secundară puternică, rezultate în urma folosirii îndelungate a vaselor pentru prepararea hranei.

Oala cu toartă de diferite dimensiuni este forma cea mai răspândită. Din punct de vedere cantitativ, al fragmentelor recoltate, această formă predomină atât în nivelul de locuire anterior construirii hanului, cât şi din nivelele legate de existenţa sau abandonarea acestei construcţii. Fragmentele descoperite în umplutura locuinţelor care au precedat existenţa hanului sau în straturile de nivelare precedente construirii hanului se datează în a doua jumătate a secolului al XV-lea şi până 
în prima jumătate a secolului al XVII-lea. Analogii apropiate pentru datare am găsit în materialul ceramic recoltat din cercetările arheologice efectuate la Curtea Veche sau la biserica Sfântul Gheorghe (Morintz et alii 1959, 259, fig. 17/1-5).

Oalele cu toartă au în general corpul piriform, sau au umeri larg rotunjiţi, diametrul gurii fiind mai mare decât diametrul bazei. Toarta se prezintă ca o bandă lată, ovală în secţiune, uşor supraînălţată, care se prinde sub muchia buzei și în zona maximă de arcuire a corpului (Pl. IX/5, 17, 23). Profilul buzelor este diferit: fie buza este scurtă, foarte puţin evazată, uşor arcuită spre interior, cu muchia rotunjită, fie buza este înaltă, dreaptă sau evazată, cu muchia subţiată, rotunjită sau teşită oblic sau orizontal (PI. VIII/1, 3-4, 6-9, 21, 22, 34). Gâtul de obicei este scurt, ca o şănţuire mai mult sau mai puţin pronunţată, după care se dezvoltă umărul vasului arcuit larg, ceea ce corespunde zonei diametrului maxim. În toate cazurile fundul vasului este drept și de multe ori se poate observa pe suprafata lui, imprimată în pasta crudă, urma sforii cu care a fost desprins vasul de pe roata olarului (PI. IX/27; VIII/19).

Decorul acestor forme de vase se prezintă în mai multe variante de realizare şi de distribuţie, pe suprafaţa exterioară a buzei sau pe umerii şi pereţii vasului. Începând din secolul al XV-lea şi în secolul următor se constată folosirea ambelor modalităţi de decorare, aşa cum întâlnim în inventarul arheologic al aşezărilor rurale şi urbane din această perioadă. Decorul incizat sub forma a 1-3 linii paralele îl întâlnim plasat pe suprafaţa exterioară a buzei, uneori imediat sub muchia ei, alteori în zona mediană a peretelui. Fascicolele de linii paralel trasate cu angoba albă, de diferite grosimi, erau plasate atât pe suprafaţa exterioară a buzei cât şi deasupra umărului, la baza gâtului sau în zona de maximă arcuire a pereţilor vasului. Spre sfârşitul secolului al XVI-lea şi începutul celui următor fascicolele de linii paralele, uneori spirale concentrice, sunt de asemenea trasate cu angobă albă şi dispuse pe o suprafată mai mare din peretele vasului, uneori şi pe suprafaţa exterioară a buzei. Tot o inovaţie decorativă a epocii o reprezintă faptul că buza teşită orizontal este şi ea decorată cu dungi scurte, vertical, trasate tot cu angobă albă, iar în unele cazuri această manieră de decorare se extinde şi pe partea superioară a tortii $(\mathbf{P l}$. IX/10, 17, 21).

În cursul secolelor XVII-XVIII, profilul oalelor cu toartă se modifică foarte puţin, astfel că vom întâlni şi forme de dimensiuni mai mari, cu corpul ceva mai rotunjit, cu pereţii şi fundul mai gros, iar pe suprafaţa interioară a pereţilor se observă coaste bine profilate, realizate în momentul modelării la roată (PI. IX/31). La rândul lor, torţile devin mult mai plate, mai late și sunt îndoite aproape în unghi drept. Chiar şi modalitatea de preparare a pastei se schimbă: pasta compactă, omogenă, are ca degresant nisip fin, pietricele foarte mărunte şi urme de scoici pisate fin. În urma arderii, pereţii, mai groşi acum, au miezul de culoare cărămiziu spre roz sau cenuşiu deschis.

Din punct de vedere al evoluţiei decorului, în această perioadă constatăm procesul de generalizare a folosirii smalţului, de culoare verde închis, oliv sau maro. Cele mai multe fragmente au muchia buzei acoperită cu o peliculă de smalţ subţire, inegal aplicată, care se întinde şi pe partea superioară a torţii. În alte cazuri suprafaţa exterioară a vasului este acoperită până la jumătate din înălţimea vasului cu un strat de smalţ verde, iar pe umăr sunt desenate spirale realizate cu smalţ de culoare oliv, iar în zona de maximă bombare sunt trasate 3-5 fascicole de linii paralele, tot cu smalţ de culoare oliv. Jumătatea inferioară a vasului este şi ea uneori acoperită, până spre linia fundului, cu angobă albă. Indiferent de dimensiunea vasului, aproape pe toate fragmentele se constată că suprafaţa interioară a vasului a fost acoperită cu o peliculă subţire de smalţ verde sau maro-deschis.

O variantă a formei mai sus prezentată, de mai mici dimensiuni, dar asemănătoare după profil, este ulcica. În inventarul ceramic al nivelelor ce corespund secolului al XVIIIlea, mulţimea fragmentelor, din păcate neîntregibile, arată că această formă este predominantă. Aceste vase aveau gura largă, corpul bombat cam la jumătate din înălţime şi fundul plat. Buza era de obicei scurtă, uşor răsfrântā spre exterior, triunghiulară în secţiune, sau cu marginea lăţită şi şănţuită, având muchia superioară subţiată şi rotunjită uşor, iar muchia inferioară bine marcată, ca 
un prag. Desenul acestui profil aminteşte profilul oalelor borcan sau al oalelor cu toartă din secolul al XIV-lea descoperite la Basarabi (Busuioc, Vâlceanu 1976, 498, fig. 1/3-7, 500, fig. 3/1), Zimnicea (Tânţăreanu 2010, 157, pl. LX/13-19), Coconi (Constantinescu 1972, 248, pl. XIV/1, 3). Şi la aceste vase gâtul este scurt şi puţin profilat, iar pereţii sunt ceva mai groşi şi prezintă pe suprafaţa interioară coaste, de sus până spre bază sau numai în registrul inferior. Toarta este plată, cu muchiile rotunjite, şi se prinde sub muchia buzei şi în zona mediană, pe linia de maximă bombare. Suprafaţa interioară şi muchia buzei sunt acoperite cu smalţ verde închis, iar suprafał̧a exterioară este acoperită complet cu angobă albă (PI. VII/23).

Oala cahlă, ca formă a ceramicii medievale, începe să fie prezentă aproape în toate aşezările importante din cursul secolului al XVI-lea, când încep să se înmulţească descoperirile ce atestă răspândirea sobelor de teracotă în aşezările medievale. Referitor la tehnica de preparare a pastei, se constată că este lucrată din pastă fină, compactă, omogenă, degresată cu mult nisip cernut fin. După modelare, suprafeţele vaselor lucrate din această pastă erau uniformizate cu o angobă subţire, obţinută din argilă curată dizolvată în apă, care a aderat pe suprafeţele vaselor ca o pojghiţă fină, fără să îndepărteze complet asprimea pastei. În urma arderii, pereţii vaselor au căpătat culoarea cărămiziu-gălbui sau gălbui. În general aceste vase au corpul de formă tronconică, cu diametrul gurii mult mai mare decât al fundului, fiind lipsite de decor. Buza este teşită orizontal sau puţin oblic, cu muchii pronunţate. La baza buzei, peretele vasului prezintă o uşoară arcuire scurtă spre exterior, după care peretele se continuă drept, oblic spre linia fundului (PI. XI/1-2, 6, 35). De multe ori şi la aceste vase se observă pe suprafaţa interioară coaste realizate în timpul modelării la roată, mai ales la exemplarele de dimensiuni mai mari şi care se datează în cursul secolului al XVII-lea, judecând după contextele în care au fost descoperite. Variantele diferă în funcţie de dimensiunile vasului, de înălţimea buzelor, de forma muchiilor de la buze şi după curba de arcuire a umărului vasului, imediat la baza buzei. Pentru exemplarele datate mai târziu există şi unele variante de decor realizat prin trasarea unor striuri paralele incizate pe suprafaţa exterioară a buzei, prin folosirea decorului aplicat cu vopsea albă sau prin marcarea sub forma unei muchii pronunţate în zona umărului. Cele mai numeroase fragmente s-au găsit, conform situaţiei stratigrafice, în nivelele de umplutură ale locuintelor cu beci, ce au existat anterior hanului, şi în straturile de nivelare ce au precedat ridicării construcţiei. Datorită condiţiilor deosebite în care au început şi s-au desfăşurat cercetările arheologice nu suntem în măsură să ştim dacă aceste forme ceramice au fost utilizate şi în cursul secolelor XVIII-XIX. Pe de altă parte, absenţa cahlelor de pe nivelurile hanului se poate motiva prin faptul că spał̧iile nu erau încălzite, ele fiind utilizate mai ales ca magazii.

Cana cu toartă şi cu picior profilat este cunoscută în repertoriul ceramicii medievale, în Ţara Românească, încă din secolul al XIVlea, la Curtea de Argeş (Constantinescu 1984, 128, 130 cu fig. 57/2-3) sau la Basarabi (Busuioc, Vâlceanu 1976, 501, fig. 4/1). Fragmentele descoperite ne permit reconstituirea profilului acestor recipiente, a căror înălţime oscila între $15-20 \mathrm{~cm}$, cât şi a variantelor ce diferă în funcţie de forma şi înălţimea piciorului. Ele erau lucrate dintr-o pastă fină, compactă, cu mai puţin nisip fin sau mică în amestec, spre deosebire de pasta folosită la formele mai sus descrise. După modelare vasele au fost acoperite, pe ambele fețe, cu un slip roşcat-deschis sau cafeniu. Toate fragmentele atestă folosirea procedeului de ardere oxidantă, de bună calitate. De obicei diametrul gurii este apropiat sau egal cu diametrul maxim al vasului. Buza subţire este scurtă, evazată, cu muchia subţiată. Într-un singur caz cele câteva fragmente ale unei căni arată că gura era lobată în partea opusă prinderii torţii (PI. IX/18). Linia de demarcaţie între buză şi corpul vasului este sugerată printr-o slabă şănţuire (PI. VIII/27). Piciorul vaselor, de formă tronconică, cu înălţimi diferite, are baza plată sau, în unele cazuri, un umbo interior (PI. VIII/20, 25-26, 29-30). Toarta ovală, uşor aplatizată, se prindea sub muchia buzei şi sub zona de maximă bombare a peretelui vasului. În privinţa decorului, pentru exemplarele mai vechi se folosesc variante realizate din linii și pete de angobă albă. Excepție fac fragmentele de la exemplarul cu buza lobată care era decorat pe 
umăr cu un şir de alveole slab imprimate în pasta moale sub care a fost trasată o singură linie de asemenea slab incizată (PI. IX/8). Mai târziu se va folosi decorarea cu smalţ verde sau cafeniu, aplicat pe buza vasului, cât şi cu angoba albă, care acoperea întreaga suprafaţă a vasului. Majoritatea fragmentelor au fost descoperite în nivelele de locuire anterioare existenţei hanului.

Câteva fragmente aparţin unei alte forme de vas mic pentru băut, care este ceaşca cu toartă. Pasta din care au fost lucrate prezintã aceleaşi caracteristici cu cea a oalelor cu toartă. În ceea ce privește profilul, ele aveau buza foarte scurtă, subţiată, puţin evazată în exterior, cu muchia rotunjită, cu corpul rotunjit sau carenat, cu piciorul scurt, profilat, al cărui diametru este mult mai mic decât diametrul buzei sau al corpului. Toarta este uşor supraînălţată, ovală sau chiar rotundă în secţiune. Decorul era realizat prin trasarea a $2-3$ linii incizate pe umărul vasului, uneori acoperite cu pete de smalt distribuite şi pe muchia buzei sau pe suprafaţa torţii. Cele câteva fragmente au fost descoperite în nivelele de locuire anterioare ridicării hanului şi care se datează în cursul secolelor XV-XVI. În secolele XVII-XVIII fragmentele ceramice ne permit să reconstituim profilul acestor vase mici, care capătă un corp globular, cu fundul plat şi sunt smălţuite în interior, uneori parţial şi la exterior. Suprafaţa interioară este acoperită până aproape de linia fundului cu angobă albă (PI. VII/35-36).

Ulcioarele sunt forme de vase amforoidale, folosite îndeobşte pentru păstrarea şi transportatul lichidelor, fiind cunoscute în repertoriul ceramicii medievale româneşti încă din secolul al X-lea, sub mai multe tipuri (Nicolescu, Petrescu 1974, 3233). Mai întâi, câteva fragmente recoltate din nivelele de locuire anterioare ridicării hanului aparţin acelui tip, destul de bine cunoscut în secolele XV-XVI, lucrat din pastă fină, bine arsă, de culoare roşu-cărămiziu, uneori acoperit de un slip de culoare roşu închis, cu corpul amforoidal, cu gâtul cilindric şi cu o singură toartă. Toarta se prinde la jumătate din înălţimea gâtului sau mai aproape de buză şi în zona de maximă bombare a corpului vasului. Uneori, prinderea torţii de gâtul vasului este consolidată prin aplicarea unui brâu subţire din pastă ceramică, care arată ca o muchie foarte reliefată, sau este decorată cu crestături oblice. Toarta, ovală în secțiune, are pe suprafaţa exterioară aplicată o pastilă de lut, perforată, iar în interior este goală, pentru a facilita scurgerea lichidului, atunci când vasul este înclinat. Alte ulcioare, cu o singură toartă, au pe umărul vasului, în partea diametral opusă torţii, un cioc de scurgere de formă tronconică, alungită, cu vârful uneori puţin arcuit.

Dacă până în secolul al XVI-lea decorarea ulcioarelor se realiza prin trasarea unor linii lustruite în reţea (PI. IX/4), a unor linii paralele incizate sau trasate cu angobă albă şi cu pete din aceeaşi culoare, în perioada următoare, în tehnica decorativă începe să fie des folosită combinaţia de smalţ de culori diferite, precum cu cea de vopsea albă sau roşie, aplicată cu cornul. Tot acum se observă tendinţa de a acoperi suprafaţa jumătăţii superioare a vasului cu smalţ monocrom, iar în secolul al XVIII-lea se generalizează acoperirea întregii suprafețe cu smalţ verde închis.

Singura piesă întreagă a tipului de ulcior cu o singură toartă, descoperită în cercetările noastre, este lipsită de decor. Aceasta a fost lucrată dintr-o pastă cu mult nisip în amestec, bine arsă, de culoare gălbui-roşcat. Gâtul subţire, uşor tronconic, nu este prea înalt şi are buza vag îngroşată şi lobată. Corpul are o formă aproape sferoidală, cu diametrul fundului mai mare. Toarta pomeşte aproape de la mijlocul înălţimii gâtului şi se prinde de corpul vasului în zona diametrului maxim (PI. VII/34). Datorită faptului că nu cunoaştem analogii pentru acest exemplar şi nici condiţiile stratigrafice ale locului de descoperire nu sunt relevante, nu ne putem pronunţa asupra unei încadrări cronologice precise. $\mathrm{O}$ piesă asemănătoare a fost descoperită la Bradu, în judeţul Buzău, şi se presupune că această formă ceramică poate fi atribuită populaţiei săseşti (Chicideanu 1979, 428).

Forma ulciorului în secolul al XVIIIlea diferă foarte puţin în comparaţie cu cea cunoscută în secolele anterioare. Gâtul cilindric sau bitronconic este uneori mai scurt, dar corpul îşi păstrează forma amforoidală şi fundul plat. Toarta sau cele două torţi simetrice se prind de zona mediană a gâtului şi în zona de maximă arcuirç a 
profilului vasului. Torţile sunt plate, cu marginile alveolate (PI. VII/13-15). Pe umărul vasului, uneori pe suprafaţa corpului şi pe toartă sunt aplicate pastile crestate, din lut, acoperite de asemenea cu smalţ. Prin compararea materialului ceramic ce aparţine secolului al XVIII-lea, descoperit la Hanul Constantin Vodă, cu materialul ceramic datat în aceeaşi vreme, descoperit în alte puncte cercetate arheologic de pe raza oraşului Bucureşti, constatăm că acest tip de ulcior reprezintă o formă unică, de serie mare, care va intra în tradiţia ceramicii populare din secolul următor.

$\mathrm{O}$ formă mai rară în ceramica de uz este castronul reprezentat doar prin câteva fragmente neîntregibile, lucrate din pastă roșie cărămizie, compactă, fină, preparată cu multă mică în amestec. Profilul fragmentelor găsite ne ajută să reconstituim cu oarecare aproximaţie forma acestor vase. Buza este teşită orizontal, cu o muchie groasă trasă spre exterior, sau este trasă oblic spre exterior, cu muchia teşită vertical; pereţii sunt drepţi, oblici sau cu o muchie bine profilată în exterior. Decorul este simplu, realizat din striuri orizontale, slab incizate, paralele şi în val ascuţit. Un singur fragment prezintă pe suprafaţa interioară a buzei o linie simplă în val, incizată (PI. IX/7). Aceste motive decorative se întâlnesc pe fragmentele ce se datează în cursul secolelor XIV-XV (Diaconescu, Ionescu 1979, 359; Constantinescu 1984, 132-133) dar pe parcursul secolelor următoare se va generaliza decorul cu smalt monocrom sau cu mai multe nuanţe aplicate sub formă de linii sau pete pe fondul monocrom $(\mathbf{P l}$. VI/16, 30).

Capacele pentru oale sunt reprezentate prin foarte puţine fragmente lucrate din pastă fină, bine arsă, de culoare roșcat-cărămizie, de formă tronconică, cu o singură toartă, cu secţiune ovală. Un singur fragment prezintă pe suprafaţa exterioară un decor realizat prin incizarea unei linii în val şi a unor alveole puţin adâncite în pasta crudă, repartizate aproape de marginea capacului. Acest fragment a fost descoperit în nivelul de locuire anterior ridicării construcţiei hanului.

În nivelele de locuire cu ceramică ce se datează în secolele XVII-XVIII s-au descoperit şi câteva fragmente de sfeşnice, lucrate în pastă ceramică, de bună calitate, decorate cu angoba albă şi cu pete de smalţ, de culori diferite (PI. VII/25). Ele aparțin unei forme a cărui profil îl cunoaştem încă din secolul al XIV-lea, dar sunt mai îngrijit lucrate. (Constantinescu, 1972, 271, pl. XXXVIV/1; Constantinescu 1984, 134). De obicei corpul este tronconic, relativ înalt, gol în interior, sprijinit pe un suport sub forma unei tipsii rotunde, cu un diametru mai mare, cu marginile îngroşate sau uşor ridicate vertical. Toarta arcuită se prinde sub muchia corpului tronconic şi la baza lui sau de marginea suportului-tipsie.

O formă de vase folosite la prepararea hranei, mai rar întâlnită în inventarul ceramic al altor aşezări rurale sau urbane, este tigaia cu coadă şi cu trei picioare tronconice, cu vârfurile uşor arcuite. În general corpul vasului are o formă tronconică, cu diametrul gurii mai mare decât al bazei. Marginea buzei este fie teşită orizontal, scurtă, tubulară în secţiune, şi se prinde de peretele recipientului imediat sub marginea buzei. Cele câteva fragmente descoperite arată că suprafaţa interioară şi muchia buzei erau acoperite cu o peliculă slabă de smalţ verde sau maro deschis. Cele câteva fragmente neîntregibile, descoperite în cursul cercetărilor, aparţin acestei forme de vas a cărei analogie o găsim în exemplarul intreg ce a fost descoperit la Curtea Veche din Bucureşti şi care datează din secolul al XVIIIlea (Rosetti 1959, pl. CXIII/ 12).

Sparte intenţionat, după ce au fost folosite, puşculitele din lut ars sunt şi ele prezente în inventarul ceramic descoperit în cercetările de la Hanul Constantin Vodă. Aceste piese de dimensiuni relativ mici, cu diametrul de $7 \mathrm{~cm}$, erau lucrate din pastă fină, arsă brun-roşcat, cu pereţii groşi, şi aveau o formă sferică sau bitronconică, rotunjită, sprijinită pe o bază rotundă, scundă, plată, uşor profilată. Gura este sub forma unei crestături făcută în pastă crudă, înainte de ardere. Corpul era decorat, uneori, cu câteva dungi de angoba albă, trasate paralel, orizontale. Aceste pușculițe apar relativ mai des şi în alte zone ale cercetărilor arheologice din București şi par să se fi bucurat de atenţie şi folosinţă în cursul secolelor XVIII-XIX (Rosetti 1959, 163-164, fig. 59).

În categoria ceramicii smălţuite predomină în general forme de vase deschise şi scunde - farfurii şi străchini - smălţuite pe 
toată suprafaţa interioară şi pe suprafaţa exterioară doar în zona marginii, cât şi vase puţin înalte smălţuite pe ambele feţe. În privinţa tehnicii de decorare cu smalţ se poate observa că în cursul secolelor XVII-XVIII aplicarea petelor de smalt colorat este combinată cu decorul realizat cu angoba albă și roşie. Din punct de vedere cantitativ se poate constata că mai mult de jumătate din numărul fragmentelor ceramice descoperite în cercetările noastre îl reprezintă fragmentele smălţuite, din păcate neîntregibile.

În nivelele de locuire existente anterior construirii hanului, ce apartin secolelor $\mathrm{XV}-$ $X V I$, un număr apreciabil de fragmente provin de la străchinile smălţuite cu decor sgrafittat sau aplicat. Aceste vase au corpul tronconic, cu buza trasă oblic în exterior, formând un unghi obtuz cu peretele vasului. Corpul se sprijină pe un picior inelar. Pasta ceramică este foarte fină şi bine arsă, de culoare cărămiziu deschis. Înainte de acoperirea cu smalţ, pe suprafața interioară a vaselor se aplica un strat de pastă albă şi se inciza desenul decorului. De obicei decorul central apare sub forma unui medalion rotund sau sub formă de rozetă. În jurul lui, pe pereţii străchinilor, până spre buză, sunt aplicate alte motive decorative sub forma de fascicole de linii, cercuri concentrice, împletituri de ghirlande sau triunghiuri dispuse cu vârfurile în jos, spre medalionul central. Se poate spune că în general decorul folosit este 0 combinaţie de motive geometrice şi florale redate într-o largă gamă de variante şi diferit colorate din punct de vedere al nuanţelor de smalţ combinate (pl. VI/ 9, 26, 28) (Rosetti 1959, pl. C.I, C.X/3, 11, C.XI/3,11; Cândea 1996, 265-272, fig. 39-46).

Fragmentele ce au fost recoltate din nivelele de locuire corespunzătoare secolelor XVII-XVIII, şi chiar la începutul secolului următor, nu mai sunt decorate prin tehnica sgrafitto, fondul predominant fiind cel al smalţului de culoare deschisă, galben sau oliv cu pete de smalţ de culoare închisă aplicate peste desenul geometric. Piciorul inelar începe să fie înlocuit cu un picior plat (Pl. VI/6, 8, 10-13, 27). În privinţa analogiilor, astfel de exemplare se întâlnesc în inventarul ceramic al descoperirilor de pe raza oraşului Bucureşti, precum şi al altor aşezări cercetate arheologic.
Farfuriile sunt tot forme de vase întinse, cu pereţii oblici, cu buza evazată, lată, cu marginea teşită oblic, vertical sau vălurită. Corpul acestor forme de vase se sprijină pe un picior inelar sau pe un fund plat, profilat. Demarcaţia între baza buzei şi peretele propriu-zis este sugerată printr-o muchie pe suprafaţa interioară. Pasta ceramică și calitatea arderii, ca și tehnica de aplicare a smalţului, sunt asemănătoare cu cea a străchinilor. Repertoriul decorativ cuprinde şi în acest caz îmbinarea motivelor geometrice (ove, cercuri, triunghiuri spirale) cu motive vegetale (ghirlande de frunze, flori, rozete) şi cu pete multicolore de smalţ.

Spre sfârşitul secolului al XVII-lea şi pe parcursul secolului următor, fragmentele de farfurii predomină faţă de fragmentele de străchini. Tot pentru această perioadă se mai constată că în decorarea farfuriilor - care-şi păstrează forma şi profilul cunoscute în secolele anterioare - începe să predomine fondul de smalţ. Tot acum se mai poate observa că uneori se renunţă la smălţuirea integrala a suprafeței interioare a vasului, și, direct peste pasta fină, arsă, de culoare cărămiziu-gălbuie, se aplică decorul de cercuri concentrice sau spirale, realizat prin trasarea cu vopsea albă sau roşie, decor acoperit inegal şi dezordonat cu pete de smalt de culori diferite.

Categoria vaselor relativ înalte, în cadrul ceramicii smălţuite, este reprezentată prin câteva fragmente de castroane, boluri mici şi pahare cilindrice smălţuite monocrom sau cu mai multe nuanţe, pe ambele fețe.

Castroanele au fundul plat, $\mathrm{cu} \mathrm{o}$ muchie profilată la bază, pereții drepţi evazaţi sau foarte puţin arcuiţi, cu marginea foarte scurtă, rotunjită. Suprafaţa interioară şi cea exterioară era acoperită de obicei numai în jumătatea superioară cu smalţ monocrom, maro, verde închis sau galben deschis. De multe ori peste acest fond au fost trasate linii concentrice paralele sau alternate cu linii în val, realizate cu nuanţe de smalt verde deschis sau galben (PI. VI/29-30).

Forme mai noi, în cadrul ceramicii smălţuite, datate în cursul secolelor XVIIXVIII, sunt paharele cilindrice smălţuite cu nuanţe multicolore, atât pe suprafaţa exterioara cât şi în interior, de înălţimi diferite, între $7 \mathrm{~cm}$ şi $14 \mathrm{~cm}$, diametrul gurii 
fiind egal cu cel al bazei. Aceste forme de vase mici au toate fundul plat, uneori cu o muchie profilată, urmată de o slabă şănţuire la baza peretelui vasului. Pereţii nu sunt întotdeauna perfect verticali ci prezintă o uşoară modificare, prin îngustarea diametrului vasului în zona mediană a înălţimii vasului, sau în zona gâtului, de unde porneşte brusc, puţin evazată, buza scurtă cu marginea rotunjită sau subţiată spre exterior. În unele cazuri pe suprafaţa exterioară s-au trasat prin incizare câte $2-3$ linii orizontale, paralele plasate fie sub linia gâtului, fie la jumătate din înălţimea vasului (Pl. VI/3132). Numărul relativ mare al fragmentelor ce provin de la aceste forme de vase este motivat de specificul construcţiei, acela de han, în incinta căruia existau şi cârciumi.

Forme ale ceramicii cu funcţionalitate ornamentală sunt reprezentate prin cele câteva fragmente de discuri cu brâuri concentrice şi de cahle-placă pentru sobe. Discurile cu brâuri concentrice, decorate cu crestături sau sub forma de muchii, nesmălţuite sau smălţuite, ca şi discurile cu umbo central dezvoltat, sunt piese ceramice folosite în decorarea faţadelor exterioare ale bisericilor, încă din secolul al XIII-lea, în Tara Românească, sub influenţa arhitecturii religioase bizantine din Balcani. Pe parcursul secolelor XIV-XVII folosirea lor se generalizează, devenind forme comune ce pot fi întâlnite frecvent în inventarul arheologic al aşezărilor cercetate. Cele trei fragmente descoperite în cursul cercetărilor noastre aparţin tipului clasic de disc omamental cu 23 brâuri concentrice nesmălţuite - Pl. VII/3, 6; PI. VIII/22 (Cândea 1996, 293-295, 294 cu fig. 68) Un singur fragment aparţine formei de disc ornamental cu un umbo, parţial acoperit cu smalţ verde, care se aseamănă cu piesele de acest fel ce împodobesc turla bisericii Stelea din Târgovişte, ctitorită în secolul al XVII-lea de Vasile Lupu (Moisescu 1979, 156) dar şi de la alte biserici ridicate în cursul secolelor XVI-XVII (Pl. VII/27). Facem precizarea că aceste câteva fragmente au fost descoperite într-un strat de nivelare cu pământ adus, în care au fost şi alte fragmente ceramice.

Fragmentele de cahle-placă pentru sobe sunt foarte mărunte, atât nesmăltuite cât şi smălţuite, fiind lucrate dintr-o pastă nisipoasă cu multă mică în amestec, bine arse, de culoare roşu-închis. Fragmentele smălţuite monocrom - verde, maro sau galben deschis - sunt decorate cu motive vegetale, geometrice sau antropomorfe. Câteva fragmente de cahle-placă, nesmālţuite, aparţin acelor piese în decorarea cărora a fost folosită o temă iconografică foarte răspândită în cursul secolului al XVIlea, cea a Sfântului Gheorghe în luptă cu balaurul (Pl. VII/11). Tot din aceeaşi perioadă datează şi un fragment de torsadă, lucrat din lut ars, care se aplică la colţurile sobei (PI. VII/22). Tema ce înfăţşează cavaleri înarmaţi cu o sabie şi cu o lance lungă, înveşmântaţi în haine lungi prinse cu brandenburguri, o regăsim pe câteva fragmente de plăci-cahle acoperite cu un strat gros de smalţ verde închis. Ele îşi găsesc asemănarea în piesele decorate cu această temă iconografică, ce aparţine veacului al XVII-lea, care au fost descoperite în cursul cercetărilor arheologice de pe dealul Mihai Vodă din Bucureşti (Cantea 1959, 104, pl. LXXXIV, LXXXV).

Celelalte fragmente de cahlă-placă smălţuite monocrom au fost decorate cu ramuri de frunze, buchete de flori sau cu suprafeţe traforate (PI. VII/1-2, 4, 5, 8-10, 12). Asemănarea acestor motive decorative cu cele descoperite în alte zone ale oraşului Bucureşti probează existenţa unor ateliere locale în care se foloseau tiparele pentru modelele decorative mai sus prezentate.

Alături de formele ceramicii româneşti, mai sus descrise, în cursul cercetărilor s-au descoperit şi câteva fragmente mărunte ce se încadrează în categoria ceramicii de import, prezentă în cadrul curţilor domnești sau a mânăstirilor, mai ales din a doua jumătate a secolului al XVI-lea şi în cursul secolelor următoare.

Cea mai mare parte a fragmentelor ceramice de import provin de la formele mici ale ceramicii otomane (cupe, boluri, cești, capace) produse în cunoscute centre de la Iznik, Cutahia, Damasc sau Constantinopol, decorate cu motive vegetale stilizate, pictate cu albastru, verde sau roșu pe porţelan, acoperite cu smalţ. Exemplare ale ceramicii otomane, fragmentele descoperite în cursul cercetărilor noastre, au fost antrenate în straturile de nivelare sau în umplutura unor 
complexe ce se datează în cursul secolelor XVI-XVIII.

Alte piese specifice ceramicii otomane sunt pipele din lut ars, de culoare roşie, neagră sau cenuşie, cu decor variat, prea puţin cercetate pentru a asigura pe baza tipologiei o încadrare cronologică mai riguroasă (PI. VII/16; $X / 1-5)$. Cele câteva fragmente descoperite aparţin nivelelor de locuire din cursul secolului al XVIII-lea, datate astfel din punct de vedere al poziţiei stratigrafice şi a analizei inventarului arheologic.

Tot în categoria ceramicii de import includem şi fragmentele de farfurii din porţelan pictat, datate secolelor XVIII-XIX, ce provin din Europa Centrală sau din Anglia.

Prezentarea ceramicii descoperită în cursul cercetărilor arheologice de salvare la Hanul Constantin Vodă din București, pune în lumină generalizarea unor forme ale ceramicii medievale orăşeneşti, folosirea unor tehnici de prelucrare şi de ardere mult îmbunătăţite sub toate aspectele (prepararea pastei, folosirea roţii rapide, tehnici de ardere şi de decorare) şi gradul de specializare al meşterilor olari. Aşa cum am încercat să arătăm, majoritatea fragmentelor ceramice descoperite aparţin unor forme ce-şi găsesc similitudinea în inventarul arheologic al altor sectoare cercetate de pe raza oraşului București. În stadiul actual al cercetărilor ele pot contribui la alcătuirea unui repertoriu care să evidenţieze producţia atelierelor olarilor locali, pe durata secolelor XVI-XVIII, în cadrul producţiei meşteşugăreşti urbane.

\section{CATALOGUL ARTEFACTELOR CU DATARE INTRINSECĂ GĂSITE ÎN TIMPUL LUCRĂRILOR DE SALVARE DE LA HANUL CONSTANTIN VODĂ}

\section{Emest OBERLÄNDER-TÂRNOVEANU}
a) Moldova - Dabija Vodă (1661-1665) imitaţie după monedele poloneze (schilling) ale lui Jan Cazimir (1648-1668)
1. AE. $0,40 \mathrm{~g} ; 14,5 \times 12,5 \mathrm{~mm}$, îndoită MRB, 1037, tip general
U.S. 813 (nr. $54^{40}$ )

\section{b) România - Carol I (1866-1914)}

5 bani

2. $\mathrm{AE}, 4,20 \mathrm{~g} ; 25 \mathrm{~mm}$.

MRB, 6-6a

Casetă Est, Complex 24 (nr. 11)

10 bani

3. AE, $9,80 \mathrm{~g} ; 30 \mathrm{~mm}$.

MRB, 7. Birmingham, Watt \& Co.

Casetă Est, latura de Est, în tranşeul de canalizare care distruge Z.10 (nr. 45)

4. AE, $9,80 \mathrm{~g} ; 30 \mathrm{~mm}$.

MRB, 7. Birmingham, Watt \& Co.

Casetă Est, latura de Est, în tranşeul de canalizare care distruge Z.10 (nr. 44)

c) Ungaria -Ferdinand I (1526-1564)

5. AR, $0,20 \mathrm{~g} ; 15 \times 10 \mathrm{~mm}$., fragmentară $(1 / 2)$

HUSZAR, 935. Kremnitz, 1551

C. $8,-1,69$ m. (nr. 14)

6. AR, $0,20 \mathrm{~g} ; 15,1 \times 9,8 \mathrm{~mm}$., fragmentară $(1 / 2)$

HUSZAR, 935-961, tip general

C. 7, -1,7 m., U.S. $717-718$ (nr. 52)

7. AR, $0,10 \mathrm{~g} ; 14 \times 12,1 \mathrm{~mm}$; fragmentară şi dublu perforată; uzată HUSZAR, 935-961, tip general

Caseta Est, C. 2, $-0,9$ m. (nr. 13)

Ungaria - emitent neprecizat (sec. XVIXVII)

dinar

8. AR, $0,60 \mathrm{~g} ; 12,2 \times 7,3 \mathrm{~mm}$; fragmentară

passim

d) Austria - Ferdinand I (1835-1848)

3 kreuzeri

9. $\mathrm{AR}, 1,30 \mathrm{~g} ; 17,9 \times 17,8 \mathrm{~mm}$; perforată

CRAIG, 188.1. Viena, 1835 A.

Caseta Est, C. 2, $-0,65$ (nr. 53)

e) Imperiul Romano-German

Nürenberg, Casa Albrecht Darn

Jeton (Rechnungpfennig)

(Secolele XVII-XVIII)

10. AE, $0,80 \mathrm{~g} ; 18 \times 18,9 \mathrm{~mm}$;

tip corabie

\footnotetext{
${ }^{40}$ Numerotarea de şantier a inventarului arheologic.
} 
Caseta Est, extremitatea nord, $-1,3 \mathrm{~m}$. (nivelul de amenajare al substructurii de bușteni) (nr. 23)

f) Prusia - Albrecht I

schilling

11. AR, $0,60 \mathrm{~g} ; 19,3 \times 17,7 \mathrm{~mm}$.

HC,...Königsberg, 1558.

C. 8, U.S. 863, caro $\mathrm{N}$, lângă martor, 2,1 m. (nr. 41)

g) Spania - Isabella I (1833-1868)

Capac de flacon de cosmetice

12. $\mathrm{AE}, 5,4 \mathrm{~g} ; 62,4 \times 59,8 \mathrm{~mm}$; deformată

Legenda: VIOLET//*PROVEEDOR

PRIVILEGIADO POR S. M. LA

REYNA DE ESPAÑA// PERFUMISTA.

În centru stema regatului.

Caseta Est, C. 2, $-0,5$ m (nr. 56)

h) rondelă de metal pentru bijuterii

13. AE, $0,50 \mathrm{~g} ; 16,2 \times 15,1 \mathrm{~mm}$;

Caseta Est, C. 2, $-0,4$ m. (nr. 50)

Lotul mai cuprinde şi fragmente de la două monede medievale, probabil din secolele XVI-XVII (numerele de şantier 51 şi 57).

6. STUDIU SEDIMENTOLOGIC ŞI

MICROMORFOLOFIC

Constantin HAITĂ

\section{6.a. INTRODUCERE}

Studiul sedimentologic şi micromorfologic realizat în situl arheologic Hanul Constantin Vodă ${ }^{41}$ a avut în vedere două obiective principale:

- studiul în teren al succesiunilor stratigrafice şi identificarea principalelor tipuri genetice de unităţi sedimentare;

- studiul micromorfologic al unităţilor sedimentare identificate.

Studiul succesiunilor sedimentare a fost realizat pe profilelor stratigrafice din suprafeţele cercetate arheologic, corespunzătoare camerelor 1-4. Acesta constă din descrierea la nivel macroscopic a unităţilor sedimentare identificate în teren,

\footnotetext{
${ }^{41}$ Principalele rezultatele ale acestui studiu au fost prezentate în comunicarea susţinută la Sesiunea Naţională de Rapoarte Arheologice, Bucureşti, 12-15 iunie 1997.
}

conform criteriilor diagnostice ce vor fi atribuite principalelor categorii de procese de formare: antropice şi naturale -fizicochimice şi pedologice. Ierarhizarea acţiunilor izolate sau corelate ale factorilor antropici şi naturali permite stabilirea unei tipologii de faciesuri sedimentare (Haită 2003, 80). Principalele caracteristici sedimentare observate sunt: textura, structura, culoarea, natura constituenţilor —naturali şi antropici, omogenitatea şi gradul de compactare. Un facies sedimentar poate fi definit ca o sumă de caracteristici diagnostice, ce poate fi atribuită unui anumit mod de formare. Informaţii detaliate asupra acestor caracteristici sunt obţinute prin analiza micromorfologică, ce este realizată în secţiune subţire, la microscop. Pentru aceasta, este necesar ca eşantioanele sub formă de blocuri, prelevate în stare nederanjată şi orientate, să fie impregnate cu o răşină sintetică şi prelucrate mecanic în scopul obţinerii secţiunilor subţiri. Secţiunile micromorfologice, cu o grosime de 25-30 microni, permit realizarea analizei la microscopul optic, în lumină polarizată, asupra texturii, microstructurii, naturii chimice şi mineralogice a constituenţilor, ca şi a limitelor dintre diferite unităţi sedimentare şi asupra gradului de omogenitate şi de compactare, în scopul stabilirii caracterului primar (in situ) sau secundar al acumulărilor, ca şi a efectelor transformărilor suferite de sedimente din momentul acumulării lor până în prezent.

6.b. STUDIUL SEDIMENTOLOGIC

Analiza sedimentologică, la nivel macroscopic, a permis elaborarea unei tipologii de faciesuri sedimentare, ce va fi prezentată în cele ce urmează.

\section{6.b.I. Faciesuri de amenajare}

Unităţile sedimentare de amenajare corespund unor niveluri acumulate antropic în scopul realizării unor amenajări pentru podea şi a unor nivelări.

În cadrul succesiunilor sedimentare studiate, amenajările pentru podele sunt realizate din sedimente cu textură argiloasă şi siltică, în unele situaţii fiind acoperite de podele de lemn. Textura acestor unităţi de amenajare este, în majoritatea cazurilor, mult mai fină decât matricea sedimentară a altor unităţi sedimentare, ceea ce indică o selecţie 
a sedimentelor utilizate, prelevate cel mai probabil din zone cu sedimentare calmă (sedimente lacustre, acumulări de aluviuni fine), având în vedere şi caracterul organic al acestora.

Unităţile de nivelare au fost încadrate în două categorii distincte: nivelări fără aport de sedimente, ce sunt realizate din materiale ce provin din distrugerea unor structuri sau elemente de construcţie sau/şi amenajare, şi nivelări cu aport de sedimente, constituite în general din sedimente cu textură fină (siltică). Aceleaşi tipuri de materiale sunt întâlnite şi în umpluturile gropilor de par.

Din punct de vedere al amenajării spaţiului locuit, a fost observată o diferenţiere atât cronologică, corespunzător celor trei paliere analizate, cât şi în cadrul aceluiaşi nivel de locuire, de la un spaţiu (cameră) la altul.

\section{6.b.II. Faciesuri de activitate}

Unităţile sedimentare atribuite acestui tip de facies sunt reprezentate prin niveluri de acumulare formate predominant prin activităţile antropice din cadrul spaţiului locuit şi constau în general din niveluri fine cu structură granulară, de acumulare a constituentilor antropici sau naturali. Natura acestor constituenţi şi gradul transformărilor fizico-chimice suferite de sedimentele acumulate pot oferi informaţii importante despre activităţile umane şi condiţiile de mediu asociate acestor transformări.

Astfel, din punct de vedere al modului de acumulare, au fost diferenţiate acumulări in situ, caracteristice unor zone de activitate antropică, acumulări secundare, rezultate prin dispersia constituenţilor antropici într-o zonă aflată în relaţie spaţială cu locul de producere a acestora, şi acumulări temare, acumulate prin deplasarea intenţionată într-o zonă de deşeuri menajere, respectiv în umplutura unei gropi de deşeuri.

Studiul acestor unităţi sedimentare este detaliat prin analiza micromorfologică, în scopul identificării activităţilor antropice şi a modului de utilizare a spaţiului locuit.

\section{6.b.III. Faciesuri de distrugere}

Unităf̧ile sedimentare corespunzătoare distrugerii unor structuri sau elemente antropice prezintă o mare variabilitate, atât din punct de vedere al constituenţilor, cât şi al modului de acumulare. Astfel, au fost observate distrugeri constituite predominant din cărămidă şi mortar, distrugeri constituite din mortar şi cărbune, distrugeri cu fragmente de tencuială şi distrugeri şi resturi de preparare din sedimente siltice şi argiloase.

\section{6.b.IV. Faciesuri naturale}

Unităţile sedimentare formate predominant sub acţiunea factorilor naturali sunt reprezentate în general prin niveluri ocupaţionale exterioare, formate în zone cu acţiune antropică scăzută.

Nivelurile naturale studiate corespund unor acumulări cu textură siltică, omogene (acumulate predominant prin remaniere hidrică), ce marchează perioada de abandon dintre primele două niveluri cronologice, ca şi unor orizonturi pedogenetice, observate la partea superioară a profilelor stratigrafice studiate.

O situaţie aparte este reprezentată de prezenţa unor niveluri sedimentare cu textură grosieră şi medie, ce prezintă caracteristicile unei acumulări naturale (structură sedimentară orientată şi prezenţa unor concreţiuni şi impregnaţii feruginoase, ce indică o ambianţă hidrică), ce constituie umplutura unei gropi cu dimensiuni importante. Această situaţie a fost interpretată ca reprezentând rezultatul unei acumulări naturale în interiorul unei fose.

\section{6.c. ANALIZA MICROMORFOLOGICÅ}

Pentru realizarea acestui studiu au fost analizate 10 secţiuni micromorfologice, notate de la S1 la S10, realizate pe eşantioanele prelevate în camerele $1-4$ şi pe profilul de vest al camerei 11 .

În camera 1 au fost studiate două succesiuni sedimentare, constituite din unităţi de construcţie, amenajare şi locuire.

Prima succesiune studiată (S1, Pl. XV/1) este reprezentată printr-o podea de lemn, conservată in situ (US 116, PI. XVI/2 $)^{42}$, ce a fost construită pe un nivel organic, brun roşcat, cu textură siltică nisipoasă (US $117, \mathrm{Pl}$. XVI/1) şi este suprapusă de un nivel ocupaţional organic, brun cenuşiu, cu textură siltică argiloasă (US 115, Pl. XVI/3, 4, 5). Nivelul organic din baza acestei succesiuni sedimentare prezintă caracteristici rezultate prin compactare în

\footnotetext{
42 Secvenţa stratigrafică descrisã aici este corespondentă celei numite, în secţiunea 3.g. a raportului, Camera 1 , podeaua $\mathrm{nr} .2$, la $-1,05 \mathrm{~m}$ fată de cota asfaltului.
} 
ambianţă umedă (fisuraţie sub-orizontală, integrarea constituenţilor de la suprafaţa solului în partea superioară a podelei) şi poate fi caracterizată ca o acumulare constantă de resturi organice, fragmente de coprolite şi granule de cuarţ policristalin.

Podeaua de lemn este transformată sub acţiunea factorilor fizico-chimici, în ambianţă umedă, prezintă zone carbonizate şi fibrele lemnoase dispuse în plan orizontal. Această podea este construită pe un nivel de amenajare realizat din sedimente argiloase.

Nivelul de locuire care suprapune podeaua de lemn este constituit dintr-o matrice cu textură siltică argiloasă, ce include abundente sferolite şi frecvente fragmente de coprolite, granule de oxalat de calciu şi fragmente vegetale în diferite grade de degradare. La partea superioară, acest nivel prezintă o amenajare vegetală realizată, foarte probabil, din lemn, într-o stare mai scăzută de conservare. Sferolitele reprezintă structuri cristaline fine, cu dispunere radiară a oxalatului de calciu, sursa acestora fiind atribuită de studiile prezentate în literatura de specialitate (Courty et alii 1989, 114) coprolitelor de ovicaprine. Toate aceste elemente permit afirmarea faptului că, foarte probabil, succesiunea sedimentară prezentată aici corespunde unui spaţiu amenajat, destinat acestor animale.

A doua succesiune studiată în camera 1 (S5) este constituită dintr-o alternanţă de niveluri ocupaţionale şi niveluri de amenajare realizate din sedimente cu textură siltică. Această succesiune sedimentară debutează cu un nivel granular, de culoare brun deschis US 113 (Pl. XVI/6), constituit dintr-o matrice cu textură nisipoasă, cu frecvente granule de cuart policristalin şi frecvente fragmente de cărbune şi ceramică, granule fine de cenuşă, fragmente vegetale carbonizate sau calcinate, rare oase de peşti şi coprolite. Acest nivel este interpretat ca un nivel de locuire în relaţie cu o structură de combustie, într-un spaţiu nu foarte bine întreţinut. Peste acest nivel, este construită o podea (US 110) realizată din sedimente cu textură siltică argiloasă, ce include fragmente de argilă cu micro-structură orientată, fragmente de sedimente siltice şi granule nisipoase de cuarţ, toate aceste elemente indicând un amestec realizat prin preparare mai puţin elaborată. Această podea prezintă, la partea superioară, fragmente siltice rubefiate, ce pot indica vecinătatea unei structuri de combustie. Fără să se observe un nivel ocupaţional bine individualizat, succesiunea continuă printr-un alt nivel de podea (US 109) construită de asemenea dintr-un amestec de sedimente siltice şi argilă, ce include fragmente de sedimente mai compacte ce provin, foarte probabil, din dezagregarea structurii de combustie menţionate anterior. Această succesiune se încheie cu un nivel de locuire cu textură siltică, de culoare brună, cu structură granulară (US 108, Pl. XVIV/1), ce include frecvente fragmente de dimensiuni centimetrice de cărbune, rare oase de pești şi granule de cenuşă.

În camera 4 au fost studiate patru succesiuni sedimentare. Prima dintre acestea (S7, Pl. I/2) este reprezentată printr-o succesiune de niveluri de podea şi niveluri de locuire. Primul dintre nivelurile de podea (US 418, Pl. XVIV/2) ${ }^{43}$ este constituit dintr-o argilă de culoare cenuşiu deschis, omogenă, compactă, ce prezintă la partea superioară un nivel de locuire (US 417, Pl. XVII/3) ce include frecvente fragmente de cărbune de lemn şi cărbune fin, cenuşă şi rare oase de peşti, ce poate fi atribuit unei zone de activităţi domestice culinare. Matricea acestui nivel este constituită din sedimente siltice nisipoase şi granule calcitice fine, de cenuşă. Depunerile laminare de argilă din goluri şi cele care îmbracă granulele de cuarţ, ca şi impregnaţiile feruginoase şi fosfatice de culoare galben verzui şi galben indică un spaţiu cu evoluţie în condiţii umede.

A doua succesiune sedimentară studiată în camera 4 (S9) este situată în partea inferioară a profilului și are în bază un nivel cu textură siltică, de culoare brun gălbui deschis, omogen, cu porozitate importantă (US 422, PI. XVII/4). Acesta are un caracter organic pronunţat, prezintă frecvente structuri de bioturbaţie de către faună, ce corespunde evoluţiei pedogenetice a unui nivel natural acumulat eolian $^{44}$. Frecvenţa constituenţilor

\footnotetext{
${ }^{43}$ Se referă la podeaua a doua a hanului, în ordinea construcţiei, din Camera 4 (vezi secţiunea 3.g. a raportului).

${ }_{44}$ Corespunde nivelului de abandon dintre nivelul locuintelor de secolul al XVI-lea şi momentul construcţiei hanului (final de secolul al XVII-lea),
} 
antropici, reprezentaţi prin fragmente de cărbune, granule de cenuşă, fragmente vegetale descompuse, coprolite şi rare oase de pești, indică un nivel de locuire exterior într-un spaţiu neamenajat, anterior amenajării podelei din această zonă.

Succesiunea analizată în această zonă continuă cu un nivel cenuşiu deschis, cu caracter organic, omogen, cu structură în agregate poliedrice fine (US 421, Pl. XVII/5), ce prezintă o matrice fină cu frecvente granule de cenuşă şi include frecvente fragmente de cărbune şi materiale de construcţie, interpretat, de asemenea, ca un nivel ocupaţional exterior. La partea superioară a acestei succesiuni, se observă o lentilă de sediment siltic ars (US 420) ce conţine rare fragmente de cărbune, acesta fiind interpretat ca un nivel de distrugere prin incendiere.

Cea de a treia secvenţă sedimentară studiată în camera 4 (S11, Pl. XV/3) este reprezentată printr-o succesiune alcătuită din două niveluri de podea suprapuse de un nivel de distrugere. Prima dintre podele (US 415) este realizată din amestec de sedimente cu textură siltică fină şi granule nisipoase. Acest nivel prezintă depuneri argiloase pe fisuri şi impregnaţii feruginoase galben verzui pe pereţii golurilor, ce indică un spaţiu amenajat cu evoluţie în condiţii umede. Cel de al doilea nivel de podea (US 414, Pl. XVII/6) ${ }^{45}$, de culoare brun roşcată, este realizat din sedimente siltice argiloase, este omogen şi compact. La partea sa superioară, această podea păstrează fragmentele unei cuverturi vegetale in situ. Nivelul ocupaţional corespunzător este constituit dintr-o matrice organică de culoare brună şi include granule de cărbune, oase de peşti şi fragmente carbonatice cu microstructură laminară paralelă, ce reprezintă, foarte probabil, fragmente de tencuială. Nivelul de distrugere de la partea superioară (US 413, Pl. XVIII/1) constă dintr-o acumulare cu structură granulară de fragmente cu matrice calcitică fină ce includ fragmente vegetale descompuse şi amprente vegetale, reprezentând fragmente de tencuială.

contemporan cu mica necropolã identificată spre sud (v. secţiunea 3 a raportului şi Pl. XIV).

${ }^{45}$ Cele două US $(415,414)$ sunt corespondente amenajării de podea nr. 3, din Camera 4 (v. secţiunea 3.g.).
Cea de a patra succesiune studiată în camera 4 (S13, PI. XVIII/2) este localizată pe profilul vestic şi reprezintă un nivel de incendiere $^{46}$. Aceasta conţine în bază un nivel de nisipuri grosiere şi pietrişuri fine, ce reprezintă o acumulare aluvială. Acesta este suprapus de un nivel de amenajare din sedimente siltice nisipoase ce includ fragmente vegetale descompuse fine şi cărbune de mici dimensiuni. Această succesiune se încheie la partea superioară cu un nivel de podea de lemn descompusă în stare umedă şi incendiată in situ. Prezenţa nivelului de nisip şi pietriş aluvial se explică prin faptul că nivelul de călcare din acest spaţiu era situat sub nivelul solului contemporan perioadei de utilizare. Prezenţa constituenţilor de natură antropică în nivelul de amenajare siltic poate sugera faptul că podeaua de lemn a fost amenajată într-o etapă ulterioară construcţiei.

Patru dintre succesiunile sedimentare studiate sunt localizate în exteriorul hanului, în partea extrem sudică a secţiunii, pe profilul vestic, sub Calea Victoriei (S16-S 19), în exteriorul unei structuri cu stâlpi de lemn, pe intervalul de adâncime 1,0-1,60 m față de nivelul actual $^{47}$. Scopul acestei eşantionări sistematice a fost acela de a caracteriza evoluţia acestei zone şi de a preciza, eventual, dacă structura se continua şi în exteriorul zonei cercetate ${ }^{48}$.

Întreaga succesiune este alcătuită din niveluri fine de sol cu evoluţie în condiţii umede. Succesiunea analizată este constituită în bază dintr-un nivel de argilă siltică de culoare cenuşie, ce conţine pelicule de argilă depuse pe fisuri. Acesta este suprapus de un nivel argilos de culoare galben roșcat, cu structură granulară, ce conţine frecvente fragmente sub-centimetrice de cărămidă şi cărbune fin. Acesta conţine la partea superioară niveluri argiloase fine, acumulate într-o ambianţă hidrică de energie

\footnotetext{
${ }^{46}$ Sedimentul studiat aparţine Locuinţei 2 (v. secţiunea 3.c. a raportului).

47 Se referă la amenajarea „Podului Mogoşoaiei”, descrisă pe larg în secţiunea 3.h. Profilul de referinț̆ este cel al presupuselor scânduri care au alcătuit, succesiv, suprafaţa de călcare pe stradă, de deasupra stâlpilor ingropaţi $(-1,6 \mathrm{~m})$, pe toată înălţimea de 60 de cm pe care a putut fi identificatã cert structura vechiului drum.

${ }^{48}$ Această structură, care a fost cercetată arheologic, a fost interpretată ca drum de lemn (,Podul Mogoşoaiei”, vezi secţiunea 3.h cu Pl. IV/1 şi V/2).
} 
scăzută, care la fel ca şi nivelurile fine cu structură tabulară şi fisuri sub-orizontale observate, indică o variaţie importantă a condiţiilor de mediu.

Peste acesta urmează un nivel brun gălbui, cu textură siltică fină şi structură cu agregate (S18, Pl. XV/4). Acesta din urmă este constituit, la scară microscopică, dintr-o alternanţă de niveluri carbonatice fine şi lamine de acumulare a granulelor nisipoase şi include rari constituenţi antropici. Această alternanţă este interpretată, de asemenea, ca fiind rezultatul variaţiilor condiţiilor de mediu, dizolvarea şi re-depunerea carbonatului de calciu fiind asociată cu temperaturi mai ridicate.

La partea superioară a succesiunii, a fost observat un nivel de culoare brună, cu textură siltică, mai compact, ce este rezultatul acumulării unor granule nisipoase, probabil în urma unei faze de inundaţie a zonei, urmat de acelaşi nivel de culoare brun gălbui, cu structura agregată caracteristică bioturbaţiei produsă de micro- şi mezofaună, ce prezintă depuneri carbonatice şi feruginoase pe fisuri.

Succesiunea studiată în această zonă indică o acumulare de sedimente fine într-un spaţiu amenajat în mod repetat, cel mai probabil cu scânduri/blăni de lemn. Deşi nu este exclus să fi fost descompus aproape în totalitate, cel mai probabil acesta a fost recuperat, neexistând nici măcar urme infime de lemn mineralizat. Principalele caracteristici sedimentare identificate la nivel microscopic, precum structura şi fisuraţia fină, sub-orizontală, amestecul unor agregate de sol cu textură şi omogenitate diferite şi compactarea importantă, sunt tot atâtea indicii pentru o zonă supusă frecvent variaţiilor de umiditate, inundaţiilor şi compactării în condiţii umede.

\section{6.d. CONCLUZII}

Analiza sedimentologică a succesiunilor stratigrafice din Hanul Constantin Vodă a permis evidenţierea principalelor tipuri de unităţi sedimentare antropice şi naturale. Tipologia de faciesuri sedimentare permite evidenţierea principalelor caracteristici ale depozitelor studiate şi interpretarea acestora în termenii mecanismelor de formare, respectiv a activităţilor umane şi a transformărilor postabandon.

Analiza micromorfologică detaliază studiul la scară macroscopică şi pune în valoare informaţiile despre principalele caracteristici sedimentare, în scopul de a contribui la interpretarea arheologică, cu informaţie specifică.

Astfel, au putut fi observate în secțiune subţire niveluri de podea de lut şi de lemn, care participă, alături de situaţiile prezentate în raportul arheologic (podele de cărămidă şi de lemn), la înţelegerea unităţilor de amenajare a spaţiului locuit. Prezenţa, în câteva situaţii, a refacerilor podelei indică un spaţiu amenajat sistematic, ca şi utilizarea lui continuă.

Demnă de evidenţiat este prezenţa sferolitelor atribuite coprolitelor de ovicaprine, ce indică un spaţiu destinat acestor animale. Prezența în mod repetat a oaselor de pești indică utilizarea frecventă a acestora în alimentaţie, iar depunerile fosfatice asociate cu fragmente de oase de mamifere poate sugera existenţa unui spaţiu destinat tranşării animalelor.

Desigur că această cercetare a avut în primul rând un caracter de studiu test, decât să fi constituit un studiu sistematic asupra tuturor unităţilor sedimentare, la scara întregului sit, date fiind condiţiile intervenţiei arheologice (de salvare). 
Tabel 1. Tipologia faciesurilor sedimentare la nivel macroscopic identificate în succesiunile studiate.

\begin{tabular}{|c|c|c|c|}
\hline TIP & DESCRIERE & INTERPRETARE & NR. CAZURI \\
\hline \multicolumn{4}{|c|}{ I. Faciesuri de amenajare } \\
\hline I.1.1. & $\begin{array}{l}\text { - nivel organic, compact, cu structură în fibre, } \\
\text { fără constituenţi antropici, brun roşcat; } \\
\text { - impregnaţii organice brun-roşcate în } \\
\text { nivelul de amenajare pe care îl suprapune. }\end{array}$ & $\begin{array}{l}\text { podea din lemn conservată in } \\
\text { situ. }\end{array}$ & 1 \\
\hline I.1.2. & $\begin{array}{l}\text { - nivel organic, friabil, cu structură } \\
\text { laminară; } \\
\text { - poate conţine la partea superioară foarte } \\
\text { rare fragmente de cărbune; } \\
\text { - impregnaţii organice brun roşcate în } \\
\text { nivelul de amenajare pe care îl suprapune. }\end{array}$ & $\begin{array}{l}\text { podea din lemn descompusă in } \\
\text { situ. }\end{array}$ & 4 \\
\hline I.1.3. & $\begin{array}{l}\text { - nivel milimetric cu structură laminară, } \\
\text { constituit din fragmente de cărbune } \\
\text { izometrice şi angulare. }\end{array}$ & podea din lemn incendiată. & 1 \\
\hline I.2.1. & $\begin{array}{l}\text { - nivel argilos cu structură omogenă, } \\
\text { compact, cu foarte rari constituenţi } \\
\text { antropici, culoare brun roşcat sau cenuşiu. }\end{array}$ & podea din argilă. & 3 \\
\hline I.2.2. & $\begin{array}{l}\text { - nivel siltic fin cu structură omogenă, } \\
\text { compact, conţine foarte rari constituenţi } \\
\text { antropici, culoare gălbui. }\end{array}$ & podea din sediment siltic. & 5 \\
\hline I.3.1. & $\begin{array}{l}\text { - nivel siltic cu structură granulară cu rare } \\
\text { fragmente sub-centimetrice de mortar şi } \\
\text { cărbune; } \\
\text { - prezintă culori gălbui, brun cenuşiu şi } \\
\text { galben verzui. }\end{array}$ & nivelare din sedimente siltice. & 3 \\
\hline I.3.2. & $\begin{array}{l}\text { - nivel siltic omogen, compact, cu foarte } \\
\text { rare oase de mamifere și cărbune, de } \\
\text { culoare cenuşie. }\end{array}$ & nivelare din sedimente siltice. & 1 \\
\hline 1.3.3. & $\begin{array}{l}\text { - nivel sau lentilă cu textură siltică sau } \\
\text { nisipoasă grosieră, granular, cu frecvente } \\
\text { fragmente de mortar, cărămidă şi elemente } \\
\text { de pietriş şi rare fragmente de cărbune, de } \\
\text { culoare gălbui. }\end{array}$ & $\begin{array}{l}\text { nivelare din sedimente şi } \\
\text { materiale de construcţie } \\
\text { provenind din distrugere. }\end{array}$ & 3 \\
\hline I.4.1. & $\begin{array}{l}\text { - umplutură siltică, omogenă, poroasă, fără } \\
\text { constituenţi antropici, de culoare brun } \\
\text { gălbui, cu impregnaţii roşcate rezultate, } \\
\text { probabil, din descompunerea lemnului. }\end{array}$ & umplutură de groapă de par. & 1 \\
\hline I.4.2. & $\begin{array}{l}\text { - umplutură din silturi argiloase omogenă, } \\
\text { fără constituenţi antropici, de culoare } \\
\text { cenușie. }\end{array}$ & umplutură de groapă de par (?). & 1 \\
\hline I.4.3. & $\begin{array}{l}\text { - umplutură siltică omogenă, poroasă, } \\
\text { friabilă, cu rare fragmente de cărbune, de } \\
\text { culoare brun închis. }\end{array}$ & umplutură de groapă de par (?). & 2 \\
\hline \multicolumn{4}{|c|}{ II. Faciesuri de activitate } \\
\hline II.1.1. & $\begin{array}{l}\text { - nivel siltic, granular, relativ omogen, } \\
\text { conţine rare şi fine fragmente de cărbune, } \\
\text { cărămidă şi mortar, de culoare brun dêschis, } \\
\text { cenuşiu sau gălbui. }\end{array}$ & $\begin{array}{l}\text { nivel ocupaţional în spaţiu } \\
\text { amenajat. }\end{array}$ & 6 \\
\hline
\end{tabular}




\begin{tabular}{|c|c|c|c|}
\hline II.1.2. & $\begin{array}{l}\text { - nivel siltic, granular, relativ neomogen, cu } \\
\text { frecvente fragmente ceramice şi cărbune şi } \\
\text { rare fragmente de cărămidă, mortar şi oase de } \\
\text { mamifere, de culoare brun deschis sau } \\
\text { cenuşiu. }\end{array}$ & $\begin{array}{l}\text { nivel ocupaţional în spaţiu } \\
\text { amenajat. }\end{array}$ & 3 \\
\hline II.1.3. & $\begin{array}{l}\text { - nivel argilos, omogen, compact, cu rare } \\
\text { fragmente fine de cărbune şi mortar, brun } \\
\text { deschis. }\end{array}$ & $\begin{array}{l}\text { nivel ocupaţional în spaţiu } \\
\text { amenajat. }\end{array}$ & 1 \\
\hline II.1.4. & $\begin{array}{l}\text { - nivel siltic argilos granular, cu frecvent } \\
\text { cărbune și rare fragmente fine de mortar şi } \\
\text { cărămidă, de culoare brun roşcat. }\end{array}$ & $\begin{array}{l}\text { nivel ocupaţional în spaţiu } \\
\text { amenajat. }\end{array}$ & 1 \\
\hline II.2.1. & $\begin{array}{l}\text { - nivel siltic granular, omogen, poros, cu } \\
\text { frecvente fragmente de cărbune şi rare } \\
\text { fragmente de cărămidă, mortar, ceramică şi } \\
\text { oase de mamifere, de culoare cenuşie. }\end{array}$ & $\begin{array}{l}\text { nivel ocupaţional în spaţiu } \\
\text { neamenajat. }\end{array}$ & 5 \\
\hline II.2.2. & $\begin{array}{l}\text { nivel siltic, granular, eterogen, cu frecvent } \\
\text { cărbune şi cărămidă şi rare lentile siltice, } \\
\text { mortar şi lentile de arsură, brun cenuşiu sau } \\
\text { cenuşiu închis. }\end{array}$ & $\begin{array}{l}\text { nivel ocupaţional în spaţiu } \\
\text { neamenajat; } \\
\text { include elemente din } \\
\text { distrugeri. }\end{array}$ & 3 \\
\hline II.2.3. & $\begin{array}{l}\text { - nivel siltic sau siltic argilos, granular, } \\
\text { poros, organic, cu fragmente centimetrice de } \\
\text { cărbune, cărămidă, mortar, fragmente de } \\
\text { tencuială şi lentile siltice, de culoare brun } \\
\text { cenuşiu sau brun gălbui. }\end{array}$ & $\begin{array}{l}\text { nivel ocupaţional în spaţiu } \\
\text { neamenajat; } \\
\text { include elemente din } \\
\text { distrugeri. }\end{array}$ & 4 \\
\hline II.2.4. & $\begin{array}{l}\text { - nivel argilos sau siltic argilos compact, } \\
\text { omogen, cu rare fragmente de cărbune, } \\
\text { fragmente siltice şi cărămidă, de culoare brun } \\
\text { roşcat. }\end{array}$ & $\begin{array}{l}\text { nivel ocupaţional în spaţiu } \\
\text { neamenajat; } \\
\text { include elemente din } \\
\text { distrugeri. } \\
\end{array}$ & 2 \\
\hline II.2.5. & $\begin{array}{l}\text { - nivel argilos, compact, omogen, cu rare } \\
\text { fragmente de cărbune, mortar și cărămidă, de } \\
\text { culoare brun cenuşiu. }\end{array}$ & $\begin{array}{l}\text { nivel ocupaţional în spaţiu } \\
\text { neamenajat. }\end{array}$ & 2 \\
\hline II.3.1. & $\begin{array}{l}\text { - lentilă granulară, omogenă, de cenuşă şi } \\
\text { cărbune, de culoare gri. }\end{array}$ & deşeuri de combustie. & 2 \\
\hline II.3.2. & $\begin{array}{l}\text { - nivel siltic, eterogen, organic, cu frecvente } \\
\text { fragmente de cărbune, oase de mamifere şi } \\
\text { rare fragmente de cărămidă, de culoare } \\
\text { cenuşie. }\end{array}$ & deşeuri menajere. & 1 \\
\hline II.4.1. & $\begin{array}{l}\text { - nivel omogen de cenuşă, cu abundente } \\
\text { fragmente centimetrice de cărbune de culoare } \\
\text { cenuşie. }\end{array}$ & $\begin{array}{l}\text { umplutură de groapă } \\
\text { menajeră. }\end{array}$ & 1 \\
\hline II.4.2. & $\begin{array}{l}\text { - umplutură siltică stratificată, cu nivele cu } \\
\text { frecvente fragmente de cărămidă şi mortar şi } \\
\text { rare fragmente de cărbune şi niveluri } \\
\text { organice cu rare frecvente fragmente de } \\
\text { cărbune oase de mamifere şi bivalve. }\end{array}$ & $\begin{array}{l}\text { umplutură de groapă } \\
\text { menajeră. }\end{array}$ & 1 \\
\hline II.5.1. & $\begin{array}{l}\text { - nivel siltic argilos sau siltic omogen, cu } \\
\text { structură în agregate poliedrice, organic, cu } \\
\text { impregnaţii brun roşcate, de culoare brun sau } \\
\text { brun gălbui; } \\
\text { conţine frecvente fragmente centimetrice de } \\
\text { cărbune şi rare fragmente de cărămidă, } \\
\text { mortar, ceramică și oase de mamifere. }\end{array}$ & $\begin{array}{l}\text { nivel ocupaţional în spaţiu } \\
\text { neamenajat dezvoltat pe un } \\
\text { nivel de sol. }\end{array}$ & 8 \\
\hline
\end{tabular}




\section{Faciesuri de distrugere}

\begin{tabular}{|c|c|c|c|}
\hline III.1.1. & $\begin{array}{l}\text { - nivel granular, eterogen, cu matrice siltică } \\
\text { sau nisipoasă şi abundente fragmente } \\
\text { centimetrice de cărămidă, mortar, elemente } \\
\text { de pietriş, fragmente de argilă cu dispunere } \\
\text { haotică şi foarte rar cărbune şi oase de } \\
\text { mamifere, de culoare galben deschis şi } \\
\text { galben brun. }\end{array}$ & $\begin{array}{l}\text { nivel de distrugere cu cărămidă } \\
\text { și mortar. }\end{array}$ & 8 \\
\hline III.1.2. & $\begin{array}{l}\text { - nivel granular cu textură nisipoasă, relativ } \\
\text { omogen, cu abundente fragmente de mortar } \\
\text { şi rare fragmente de cărbune şi lentile siltice } \\
\text { rubefiate, de culoare galben deschis sau } \\
\text { galben portocaliu. }\end{array}$ & $\begin{array}{l}\text { nivel de distrugere cu mortar şi } \\
\text { cărbune. }\end{array}$ & 3 \\
\hline III.1.3. & $\begin{array}{l}\text { - nivel siltic cu abundente fragmente de } \\
\text { cărbune masiv şi rare fragmente de cărămidă, } \\
\text { de culoare galben verzui. }\end{array}$ & $\begin{array}{l}\text { nivel de distrugere cu cărămidă } \\
\text { şi cărbune }\end{array}$ & 1 \\
\hline III.1.4. & $\begin{array}{l}\text { - nivel granular cu textură siltică, cu } \\
\text { abundente fragmente de tencuială dispuse } \\
\text { haotic şi rare fragmente de cărămidă, de } \\
\text { culoare alb gălbui; } \\
\text { - fragmentele de tencuială pot prezenta } \\
\text { amprente vegetale largi şi sunt constituite } \\
\text { dintr-o matrice carbonatică fină. }\end{array}$ & $\begin{array}{l}\text { nivel de distrugere cu fragmente } \\
\text { de tencuială. }\end{array}$ & 4 \\
\hline III.2.1. & $\begin{array}{l}\text { - lentilă siltică din sediment ars şi fragmente } \\
\text { centimetrice de cărbune şi cărămidă, de } \\
\text { culoare brun negricios sau galben roșcat. }\end{array}$ & distrugere siltică prin incendiere. & 4 \\
\hline III.3.1. & $\begin{array}{l}\text { - lentilă de argilă omogenă cu rare fragmente } \\
\text { de cărbune şi foarte rare fragmente ceramice, } \\
\text { de culoare brun roșcat. }\end{array}$ & $\begin{array}{l}\text { distrugere sau rest de preparare } \\
\text { din argilă. }\end{array}$ & 1 \\
\hline III.3.2. & $\begin{array}{l}\text { - lentilă siltică omogenă, compactă, fără } \\
\text { constituenţi antropici. }\end{array}$ & $\begin{array}{l}\text { distrugere sau rest de preparare } \\
\text { din sedimente siltice. }\end{array}$ & 2 \\
\hline III.4.1. & $\begin{array}{l}\text { - acumulare stratificată sau eterogenă, cu } \\
\text { niveluri din mortar şi cărămidă, pietriş şi } \\
\text { sedimente siltice cu rare fragmente de } \\
\text { cărbune şi cărămidă, de culoare galben brun. }\end{array}$ & $\begin{array}{l}\text { umplutură de groapă cu } \\
\text { materiale din distrugeri. }\end{array}$ & 5 \\
\hline
\end{tabular}

\section{Faciesuri naturale}

\begin{tabular}{l|l|l|l|l}
\hline IV.1. & • umplutură stratificată cu niveluri de pietriş, & umplutura unei fose, cu acumulare & 1
\end{tabular} nisip grosier şi fin, fără constituenţi antropici, naturală. conţine concreţiuni feruginoase, de culoare brun gălbui şi galben roșcat.

IV.2. $\quad$ nivel siltic omogen, poros, fără constituenţi antropici, de culoare gălbui.

IV.3. $\quad$ nivel siltic argilos cu structură în agregate poliedrice şi impregnaţii brun roşcate, cu foarte rari constituenţi antropici. 
Pentru a se extrage polenul, probele

\section{Mihai TOMESCU}

Palinologia aplicată în arheologie studiază sporii şi polenul produse de plante, cu scopul de a reconstitui evoluţia climei şi a vegetaţiei, în trecut, şi de a pune în evidenţă diverse aspecte ale economiei de subzistentă (cultivarea plantelor, prelucrarea plantelor alimentare, stocarea produselor agricole etc.), sau diferite alte practici legate de plante.

Prelevările palinologice efectuate în cadrul săpăturilor de salvare de pe şantierul Hanul Constantin Vodă sunt in număr de 14.

Din camera $1 \mathrm{~s}$-au prelevat 6 probe: $o$ probă din podeaua de lemn US 116, o probă din nivelul ce o suprapunea (US 115), conţinând fragmente de lemn ars, cochilii de scoici şi prezentând bioturbaţii, şi două probe din US 117 , nivelul de sub podeaua US 116; proba prelevată din baza US 117 sugera o succesiune de podele (niveluri de călcare) bioturbate ${ }^{49}$ ulterior; în afară de aceste 4 probe, în camera $1 \mathrm{~s}$-a mai făcut o prelevare din US 119 (sediment conţinând fragmente de lemn ars) şi o altă prelevare din nivelul de sub US 119, conţinând, de asemenea, fragmente de lemn ars, dar prezentând şi urme de bioturbaţie.

În camera $4 \mathrm{~s}$-au prelevat probe din US 417 -un nivel asemănător ca structură şi textură cu chirpiciul--, US418 - nivel reprezentând o succesiune de podele -, US 419 - material de construcţie, mortar? -, US 420 - o altă succesiune de podele - şi o probă din nivelul de sub US 420 , conţinând fragmente de lemn ars şi prezentând urme de bioturbaţie. Deci, din camera 4 s-au prelevat 5 probe.

Din camera 9 s-a prelevat o probă dintr-o umplutură de bordei ${ }^{50}$ şi o alta din sedimentul în care acesta fusese amenajat, reprezentat printr-un material de tip loess, carbonatic, dur.

În sfârşit, o altă probă a fost prelevată dintr-o podea de lemn pusă în evidentă în casetă.

\footnotetext{
${ }^{49}$ Strate asupra cărora au acţionat organisme ce trăiesc în sol, modificându-le structura şi textura.

${ }^{50}$ Referinţă la Locuinţa 3 (vezi secţiunea 3.c).
}

au fost mai întâi atacate cu acid clorhidric $(\mathrm{HCl})$, pentru eliminarea carbonaţilor. Pentru eliminarea silicaţilor, a urmat atacul cu acid fluorhidric (HF). După acesta, materia organică solubilă a fost eliminată prin fierbere timp de 10 minute în soluţie de hidroxid de potasiu $(\mathrm{KOH}) 10 \%$. În sfârșit, polenul, împreună cu toată materia organică figurată, a fost separat prin centrifugare în lichid Thoulet de densitate $2,0 \mathrm{~g} / \mathrm{cm}^{3}$ şi montat pe lame pentru microscopie, în glicerină (lichidul Thoulet se obţine din iodură de cadmiu, iodură de potasiu şi apă distilată).

Tratamentele chimice au arătat că sedimentul este, în general, putemic carbonatic şi are un conţinut relativ ridicat de silicaţi. Polenul, nu foarte abundent, este conservat acceptabil. Această conservare deficitară a polenului poate fi explicată în primul rând prin pH-ul bazic al sedimentelor carbonatice. Conditiile alcaline măresc susceptibilitatea exinei (învelişului) polenului la oxidare, care, la rândul său, diminuează rezistenţa la activitatea bacteriilor descompunătoare anaerobe.

În probele analizate au fost puse în evidenţă mai multe tipuri de polen, ce vor fi trecute în revistă în cele ce urmează.

Polenul de Pinus (pin) -Pl. XIX/1. Acest polen este caracterizat prin prezenţa a doi saci aeriferi, care îi măresc flotabilitatea - o adaptare excelentă pentru polenizarea anemofilă - prin intermediul curenţilor de aer. Din această cauză, polenul de pin poate fi transportat pe distanţe mari, depăşind uneori $1000 \mathrm{~km}$.

În aşezările umane şi în împrejurimile acestora sunt frecvente plantele ruderale. Ele cresc pe marginea drumurilor şi, în general, în zone cu soluri bogate în azotaţi. Îmbogăţirea solului în azotaţi este o caracteristică a locuirilor umane şi se datorează dejecţiilor animale şi umane. Cele mai tipice plante ruderale sunt plantele din familia Chenopodiaceae. Specii ruderale se întâlnesc, însă, și în familiile Asteraceae - Pl. XIX/2 - polen de Crepis biennis (gălbenuși) - Apiaceae, Brassicaceae, Lamiaceae etc. Tot ruderală este şi specia Plantago lanceolata - 
pătlagina îngustă (Pl. XDX/3) -, folosită în studiile palinologice ca indicator al antropizării mediului.

Apropierea cursului Dâmboviței explică prezenţa polenului plantelor higrofite şi hidrofite (acvatice). Printre acestea se numără Typha (papura) şi Phragmites (trestia), Cyperaceele - Cyperus (căprişor - Pl. XIX/4), Holoschoenus (pipirig), Scirpus (tipirig), Carex (rogoz), ca şi nuferii (Nymphaea şi Nuphar), Stratiotes (foarfeca bălţii), Myriophyllum (vâsc de apă), Lemna (lintiţă) etc. De asemenea legate de apropierea apei sunt apariţiile genurilor Salix (salcia), Populus (plopul) şi Alnus (arinul).

Vegetaţia câmpiei cuprinde atât arbori, cât şi plante erbacee. Dintre erbacee, caracteristice câmpiei sunt în special Gramineele. Ele sunt însoţite de specii din familiile Asteraceae, Brassicaceae, Apiaceae, Fabaceae. Gramineele cultivate (cerealele) sunt puse în evidență în palinologie prin dimensiunile polenului lor, care sunt mai mari decât cele ale
Gramineelor sălbatice. Pe de altă parte, însă, cerealele au o polenizare autogamă (polenizarea are loc în interiorul florii, fără deschiderea acesteia), deci polenul lor are o capacitate de dispersare foarte redusă. De aceea, chiar cantităţi reduse de polen de cereale demonstrează prezenţa acestora sub formă de culturi. Concentraţiile mai mari de polen de cereale sunt, de obicei, puse în legătură cu puncte de treierare a acestora.

Vegetaţia lemnoasă a câmpiei include stejarul (Quercus), carpenul (Carpinus), arțarul (Acer), teiul (Tilia), ulmul (Ulmus), frasinul (Fraxinus), salcâmul (Robinia) etc. Dintre arbuşti apar cornul (Cornus), alunul (Corylus), călinul (Viburnum), socul (Sambucus) și voniceriul (Evonymus).

În concluzie, deşi probele analizate nu sunt prea numeroase, trebuie subliniat că acesta este primul studiu palinologic efectuat într-un sit din centrul Bucureștilor, ce dă o imagine generală asupra vegetaţiei zonei.

\section{BIBLIOGRAFIE}

Bădescu, Oltean 2008

Bălășescu et alii 2002

Busuioc, Vâlceanu 1976

Cantea 1959

Cândea 1996

Chicideanu 1979

Chițescu, Teodor 1997

Constantinescu 1972

Constantinescu 1984

Courty et alii 1989
E. Bădescu, R. Oltean, Cele mai vechi și mai frumoase panorame fotografice ale Bucureştilor (1856-1877), București, 2008.

A. Bălășescu, D. Moise, V. Radu, La faune de l'auberge Constatin Vodă (XVIII ${ }^{\mathrm{e}}$ s., Bucarest, Roumanie), Revue Belge de Philologie et d'Histoire, Brussels, 80, 2002, 1449-1547.

E. Busuioc, D. Vâlceanu, Ceramica din aşezarea medievală de la Basarabi Calafat (sec. al XIV-lea), $S C I V A, 27,1976,4,495-516$.

Gh. Cantea, Cercetări arheologice pe dealul Mihai Vodă și împrejurimi, în I. Ionaşcu (ed.), Bucureştii de odinioară în lumina săpăturilor arheologice, București, 1959, 93-143.

V. Cândea, Brăila. Origini şi evolutie până la jumătatea sec. al XVI-lea, Brăila, 1996.

I. Chicideanu, O aşezare din secolele XIV-XVI la Bradu, CAMNI, 3, 1979, $421-438$.

L. Chiţescu, E.S. Teodor, Cercetări arheologice la Giurgeni-Piua Petrii, campania anului 1996, CCA 1997, clMeC (http://www.cimec.ro/ scripts/arh/cronica/detaliu.asp? $\mathrm{k}=427$ )

N. Constantinescu, Coconi un sat din Câmpia Română în epoca lui Mircea cel Bătrân, Bucureşti, 1979.

N. Constantinescu, Curtea de Argeş 1200-1400. Asupra inceputurilor Tării Româneşti, Bucureşti, 1984.

M.-A. Courty, P. Goldberg, R. Macphail, Soils and micromorphology in archaeology, Cambridge University Press, 1989. 
Diaconescu, Ionescu 1979 P. Diaconescu, C. Ionescu, Cercetări arheologice în zona fostei străzi „Rapsodia” din Târgoviște-Biserica Stelea Veche, MCA (Oradea), 1979, 353-368.

Draşovean et alii 2007 F. Draşovean, C. Feneşan, Al. Flutur, Al. Szentmiklosi, G. El Susi, Zs. Kopeczny, H. M-Kiss, R. M. Septilici, N. Dinu, Timisoara in amurgul Evului Mediu, Timişoara, 2007.

Florescu 1932

G.D. Florescu, Alaiul înmormântării lui Alexandru Nicolae Şuţu Voevod la 20 ianuarie 1821, Urbanismul, Institutul Urbanistic al României, IX, 11-12, noiembrie 1932.

Florescu 1935

G.D. Florescu, Bucureşti. Biserici, curti boiereşti și hanuri după două planuri inedite dela sfârşitul veacului al XVIII-lea, Bucureşti, 1935.

Haită 2003

C. Haită, Sedimentologie si Micromorfologie. Aplicatii in Arheologie, Târgovişte, 2003.

Mănucu-Adameșteanu $2005 \mathrm{Gh}$. Mănucu-Adameșteanu, Cronica cercetărilor arheologice în București (1999-2004), CAB, 6, 2005, 289-309.

Mihai 2005

D. Mihai, Date preliminare despre cercetările preventive de la hanul Constantin Vodă din Bucureşti (1996), CAB, 6, 2005, 271-280.

Moisescu 1979

Morintz et alii 1959

C. Moisescu, Târgovişte. Monumente istorice şi de artă, București, 1979.

S. Morintz, Gh. Cantacuzino, D.V. Rosetti, Santierul arheologic București. Sectorul Curtea Veche, Biserica sf. Gheorghe Nou, $M C A, 5,1959,631-654$.

Nicolescu, Petrescu 1974 C. Nicolescu, P. Petrescu, Ceramica românească traditională, București, 1974.

Oltean, Ionescu 2006

Panait 1963

R. Oltean, D. Ionescu, Capitala Bucureşci, 1847-1854, București, f.a. (2006) P.I. Panait, Observaţii arheologice pe şantierele de construcţii din Capitală, $C A B, 1,1963,139-176$.

\section{Păunescu,}

Teodor 2003

A. Păunescu, E. S. Teodor, L'établissement rural médiéval des XVI-XVII siecles de Brăneşti-Vadu Anei, CAMNI, 12, 2003, 249-274.

Păunescu,

Teodor 2006

\section{Potra 1943}

Potra 1985

Rosetti 1959

\section{Taloş 1980}

Tânţăreanu 2010

Tico 1979

A. Păunescu, E. S. Teodor, La nécropole de Brăneşti-Vadu Anei (le XVI siècle), CAMNI, 13, 2006, 275-308.

G. Potra, Hanurile bucureştene, Bucureşti, 1943.

G. Potra, Istoricul hanurilor bucureştene, Bucureşti, 1985.

D.V. Rosetti, Curtea Veche, în I. Ionaşcu (ed.), Bucureștii de odinioară în lumina săpăturilor arheologice, Bucureşti, 1959, 147-165.

C. Taloş, Vestigii ale Hanului Zlătari, Revista Monumentelor și Muzeelor, 17, $1,48-51$.

Ec. Tânţăreanu, Habitat medieval în sud-estul Munteniei în sec. XIV-XVII. Temeiuri istorice şi arheologice, Bucureşti, 2010.

Cr. Tico, Raport preliminar asupra cercetărilor de salvare efectuate la Hanurile Zlătari şi Constantin Vodă din Bucureşti (campania 1978), MCA (Oradea), 1979, 399-401.

Tico 1981

Cr. Tico, Contribuţii arheologice la cunoaşterea complexului arhitectonic Văcărești, $C A B, 3,1981,242-290$. 
PI. I - Calea Victoriei (Victory Avenue) between French Street and Lipscani Street. Rescue diggings in 1996. General plan.

Pl. II - State archives, Plans, Ilfov, 39: Constantin Vodă Inn, ground floor, annex to the Report no. 39, Bucharest 1848; legend (from top to bottom): a) Constantin Vodă Inn; b) buildings rendered distinctively on the original plan; c) buildings in other propriety; d) the building of the National History Museum in present days.

PI. III - 1: The position of Constantin Vodă Inn in western historic downtown: 1. Brâncoveanu Palace; 2. Podu Mogoşoaiei (Mogoşoaia "Bridge" street, today Calea Victoriei); 3. Constantin Vodă Inn (today the Historical National Museum); 4. St. John the Great Inn (today C.E.C. Palace); 5. Zlătari ("goldsmiths") Church and Inn; 6. Şerban Vodă Inn (today the National Bank); 7. St. Dumitru-"Postmail" Church; 8. Stavropoleos Church and Inn; 9. German Street (today Smârdan). On the eastern wing of Constantin Vodă Inn one can note differences between this plan of the downtown (Borroczyn 1854, in a graphic "restoration" by Radu Oltean see Oltean, Ionescu 2006) and the detailed plan of the building (Borroczyn 1848, see plate II).

PI. III - 2: Overlapping plans from 1854 (the planimetric view which supports the above axonometric view), in hatches, and the detailed plan of Constantin Vodă Inn from 1848 (see Plate II), in gray shades.

PI. III - 3: Overlapping plans of Bucharest from 1854 (Borroczyn, detail from Constantin Vodă Inn neighborhood, hatches) and 1791 (Austrian officer Ernst, in shadow). The following are numbered: 1. Constantin Vodă Inn; 2. Stavropoleos Inn; 3. St. John the Great Inn; 4. Zlătari Inn; 5. Greci (Greeks') Inn; 6. Șerban Vodă Inn; not numbered - St. Dumitru Church. Down: distinctive reproduction of the two plans: Ernst (left) and Borroczyn (right) Bădescu, Oltean 2008.

PI. IV - Rescue diggings from Constantin Vodă Inn. 1 (up) foundations of the Inn; 2 (middle) archaeological contexts before and after the Inn; 3 (bottom) overlapped plans Borroczyn (1848) and our diggings. Legend, from top to bottom: large water pipe buried in January 1996; old pipes and sewerages; landslides disturbing research; large cellars; deep buried huts; other contexts prior the Inn; pits after the Inn; brick walls uncovered in a second phase of research (fall 1996); concrete filling; wood posts infra-structure; (numbered) rooms from the Inn; altimetry of the base of the foundation $(\mathrm{cm}$, where zero is between central pillars of the National Museum's facade).

PI. V - Snapshots from Constantin Vodă Inn rescue diggings: 1. Fragment of the eastern section of the trench in Room no. 5 (see Plate 4 for location). This white and black photograph prepared for report is far from being a good guide in stratigraphy; it is nevertheless typical for the alternation of layers resulted from successive leveling with clays (noted A), altered floor boards (B, probably wood, except the latest), redevelopments with tiny mortar traces (C) and constructive debris (D). The lower part (not marked) depicts anthropic layers prior to Inn's construction; 2. Southern part of the trench, on the outer part of the Inn, in the old street, with the infrastructure made of logs buried below surface, and a suggestion for reconstruction; 3. Eastern rampart of the trench collapsed due to repeated flood; in the rear - round crops in Inn's foundation, result of urban activities between 1860 and $1890 ; 4$. Anther effect of the recent floods: foundation noted Z.10 (see plate IV) with lost emplecton, with standing brick faces.

PI. VI - Pottery from Constantin Vodă Inn (color plate).

PI. VII - Pottery from Constantin Vodă Inn (color plate 2).

PI. VIII - Pottery from Constantin Vodă Inn (drawings).

PI. IX - Pottery from Constantin Vodă Inn (drawings 2).

Pl. X - Small objects, selection.

PI. XI -1. Altimetry table (where zero is between central pillars of the Museum and the corresponding graph). Table headline (from left): walls oriented East-West; foundation trench; plinth; foot level of our time; bottom of the main wall, North-South, on the facade, corresponding to EastWest walls; first floor of the Inn;... in room no....; geologic layer.

PI. XI - 2. Altimetry for successive floors of the Inn, corresponding to each Room (noted C). Legend (from top): wooden floor on clay bed; brick pavements (or other long lasting construction materials) on clay leveling; clay leveling, but probably brick floor (recovered); clay leveling, possible former floor; sunken layers due to the natural compaction. Note that the altimetry is taken here departing from present foot level, as a more comprehensive comparative term (for correlations see plate $\mathrm{XI} / 1$ ). 
PI. XII - Legend for stratigraphic drawings. From top to bottom (left column): asphalt; organic, blackish layer, with clay spots and tiny coal traces; organic, blackish layer, with burned wood and clays (destruction layer?); dense and heavy, blackish layer, with burned wood and ashes; dark gray, with green hues (flood?); dark brown layer with burned wood; brown and dense leveling (floor infrastructure); brown, inconsistent layer (dry-rot?); clay leveling; clay leveling with impurities; yellow-reddish clay with dark spots and burned wood traces; natural clay (yellowish, consistent); clay floor, reddish-green, very compact; dark-brown layer with burned wood traces and little brick chips; (right column) blue, sandy layer; layer burned in situ; mortar; ashes; burned wood in situ; burned adobe; brick ruins; brick floor; clay substructure for a brick floor; decayed wooden floor; decayed log.

Pl. XIII - Test trench corresponding to Room 2 (see Plate 4 for location), western section, indicating the position for dated coins. See also the Legend (Plate XII).

PI. XIV - Eastem section of the archaeological trench corresponding to Room 8 (see Plate IV), indicating the position for dated coins. See also the Legend (Plate XII). On the right side - the major chronological levels of the site.

PI. XV - Scanned images of some micromorphologic sections. Image width $6 \mathrm{~cm}$. 1 . Scanned image of thin section $\mathrm{S} 1 ; 2$. Scanned image of thin section $S 7 ; 3$. Scanned image of thin section $\mathrm{S} 11 ; 4$. Scanned image of thin section S 18.

PI. XVI - Microscope photographs of the various studied sedimentary units. XPL - cross -polarized light, PPL - plane polarized light. 1. i. - image width. 1. S1 - U.S. 117. Occupational level, compacted, with fragments of charcoal. PPL, 1. i. $2 \mathrm{~mm}$; 2. S1 - U.S. 116 . Wooden floor with preserved vegetable structure. PPL, 1. i. $2 \mathrm{~mm}$; 3. S1 -S. 115. Clay floor. PPL, 1. i. $2 \mathrm{~mm}$; . S 1 - U.S. 115. Organic accumulation with vegetable fragments. PPL, I. i. $1 \mathrm{~mm}$; 5. S1 - U.S. 115. Organic accumulation, with abundant spherolites. XPL, 1. i. $1 \mathrm{~mm}$; 6. S5 - U.S. 113. Fine crystallized calcitic accumulation. XPL, 1. i. $2 \mathrm{~mm}$.

PI. XVII - Microscope photographs of the various studied sedimentary units. XPL - cross-polarized light, PPL - plane polarized light. l. i. - image width. 1. S5 - U.S. 108. Organic occupational unit with charcoals and fish bones. PPL, 1. i. $2 \mathrm{~mm}$; 2. S 7 - U.S. 418. Phosphate accumulation in voids. PPL, 1. i. $2 \mathrm{~mm}$; 3. S7 - U.S. 417. Level with abundant ash, bone fragment and charcoal. XPL, 1. i. 2 mm; 4. S9 - U.S. 422. Faunal burrowing structure. PPL, 1. i. 2 mm; 5. S9 - U.S. 421. Accumulation of ashes with bumed construction materials. XPL, 1. i. $2 \mathrm{~mm}$; 6. S9 - U.S. 414 In situ decomposed vegetable mat. PPL, 1. i. $2 \mathrm{~mm}$.

PI. XVIII - Microscope photographs of the various sedimentary units studied. XPL - cross-polarized light, PPL - plane polarized light. 1. i. - image width. 1. S9 - U.S. 413. Level of destruction with fragments of plaster. XPL, 1. i. $2 \mathrm{~mm} ; 2$. S13 - bottom. Natural accumulation of sands. XPL, 1. i. $2 \mathrm{~mm}$; 3. S13. Wooden floor burned in situ. PPL, l. i. $2 \mathrm{~mm}$; 4. S19. Sharp limit between the described levels. XPL, I. i. $2 \mathrm{~mm}$; 5. S18. Limit between fine clay units. XPL, 1. i. $2 \mathrm{~mm}$; 6. S16 - top. Calcitic accumulation in fissures. XPL, 1. i. $2 \mathrm{~mm}$.

PI. XIX - Microscopic snapshots for palinology. 1. Pinus sp. pollen $(40 \times 80 \mu \mathrm{m}) ; 2$. Crepis biennis pollen $(\phi 30-40 \mu \mathrm{m}) ; 3$. Plantago lanceolata pollen $(\phi 28 \mu \mathrm{m}) ; 4$. Cyperus longus pollen $(25 \times 35 \mu \mathrm{m})$.

Eugen S. TEODOR, Anca PĀUNESCU, Constantin HAITÃ, Emest OBERLÄNDER-TÂRNOVEANU,

Muzeul Naţional de Istorie a României

Calea Victoriei 12, 030026, Bucureşti

esteo60@yahoo.co.uk;

costel_haită@yahoo.com

\section{Mihai TOMESCU}

Department of Biological Sciences, Humboldt State University

Arcata, CA 95521, USA

mitomescu@hotmail.com 
corpuri şi părți de clădire care nu mai aparțineau hanului la 1848

amprenta la sol a Muzeului Național de Istorie a României
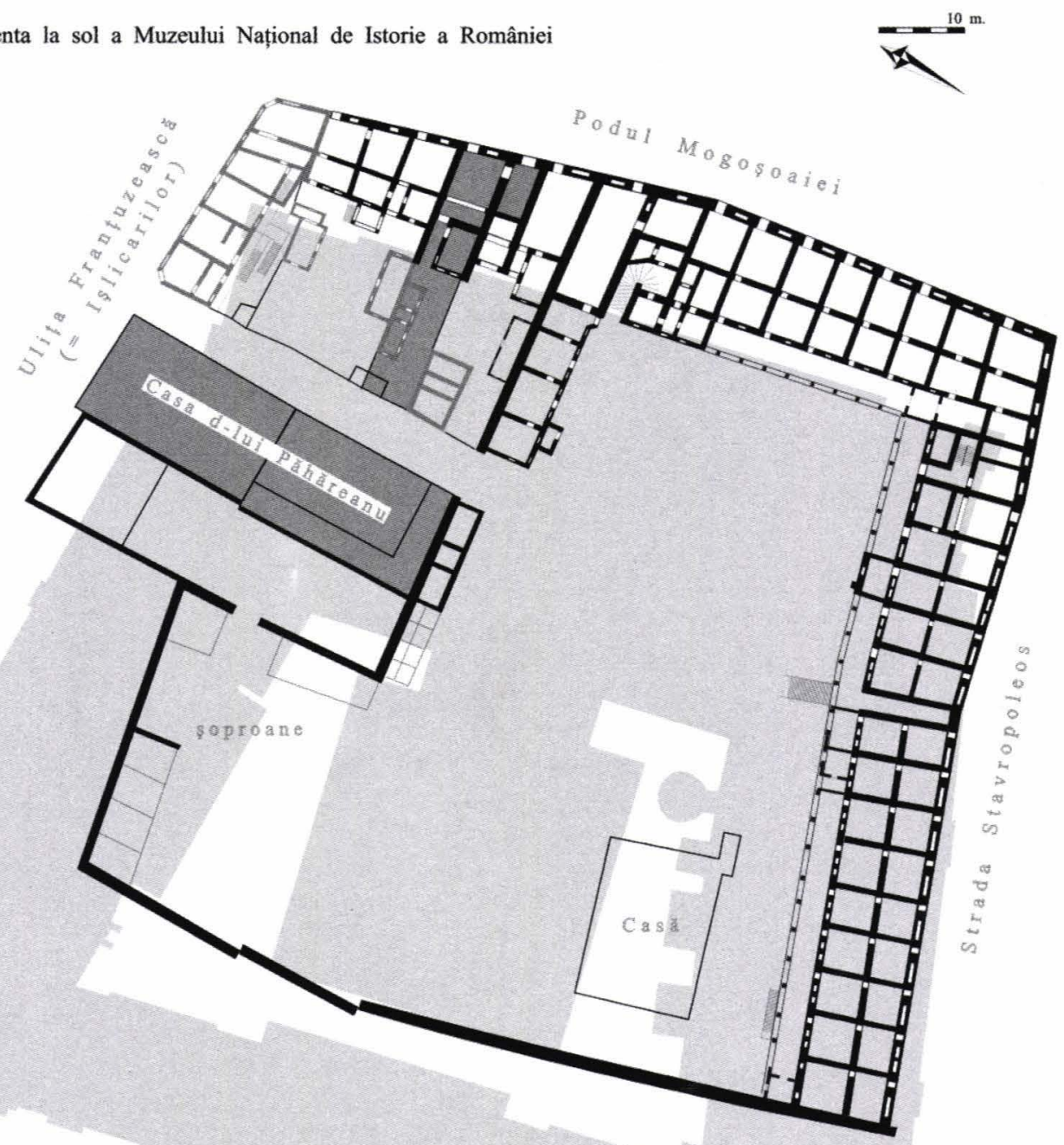

Pl. II. - D.G.A.S. Planuri, Ilfov. 39: „Planul ctitoriei Hanul Constantin Vodă pentru catul de jos, la raportul cu nr. 39. București 1948, martie 30” 


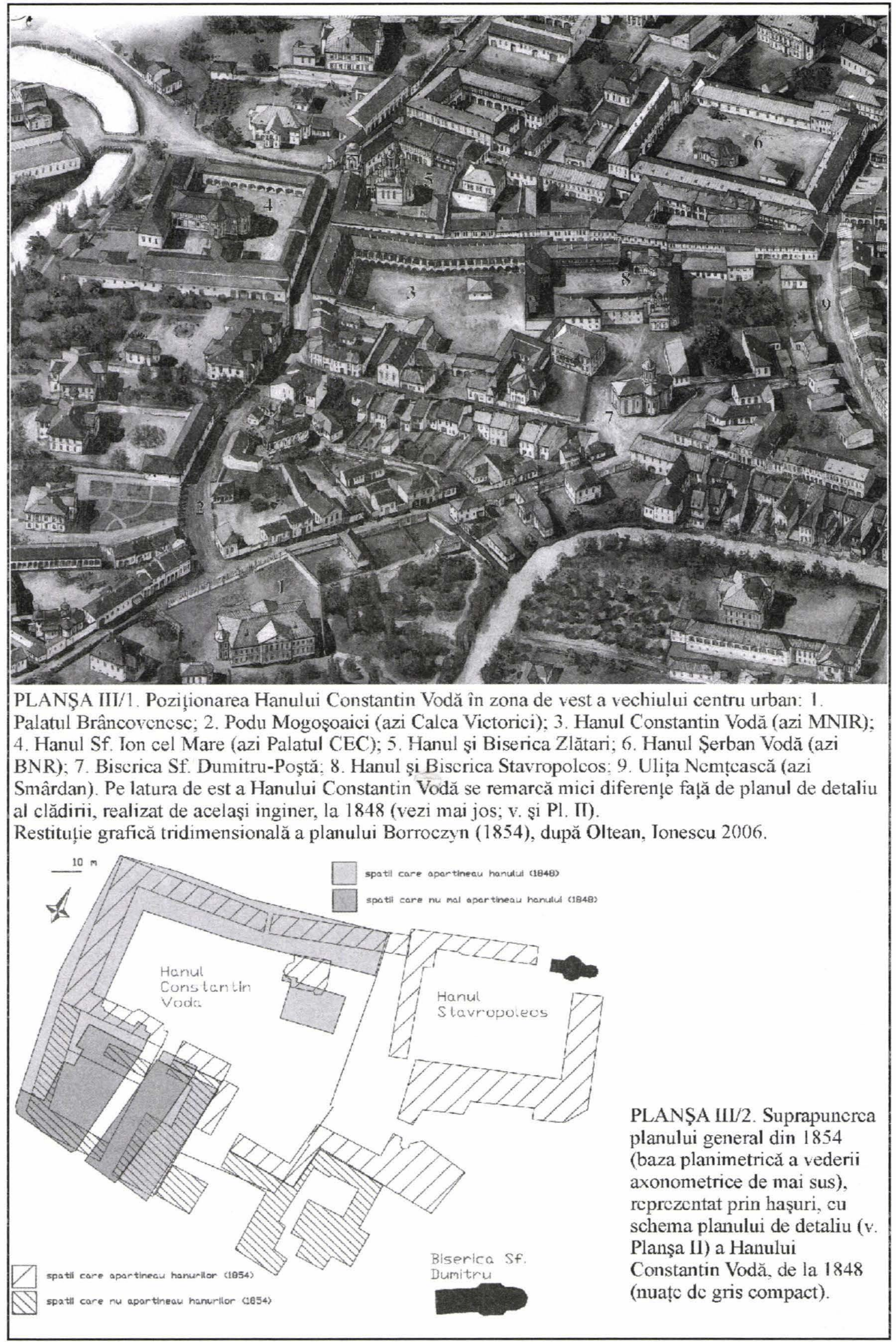

PI. III - 1-2 


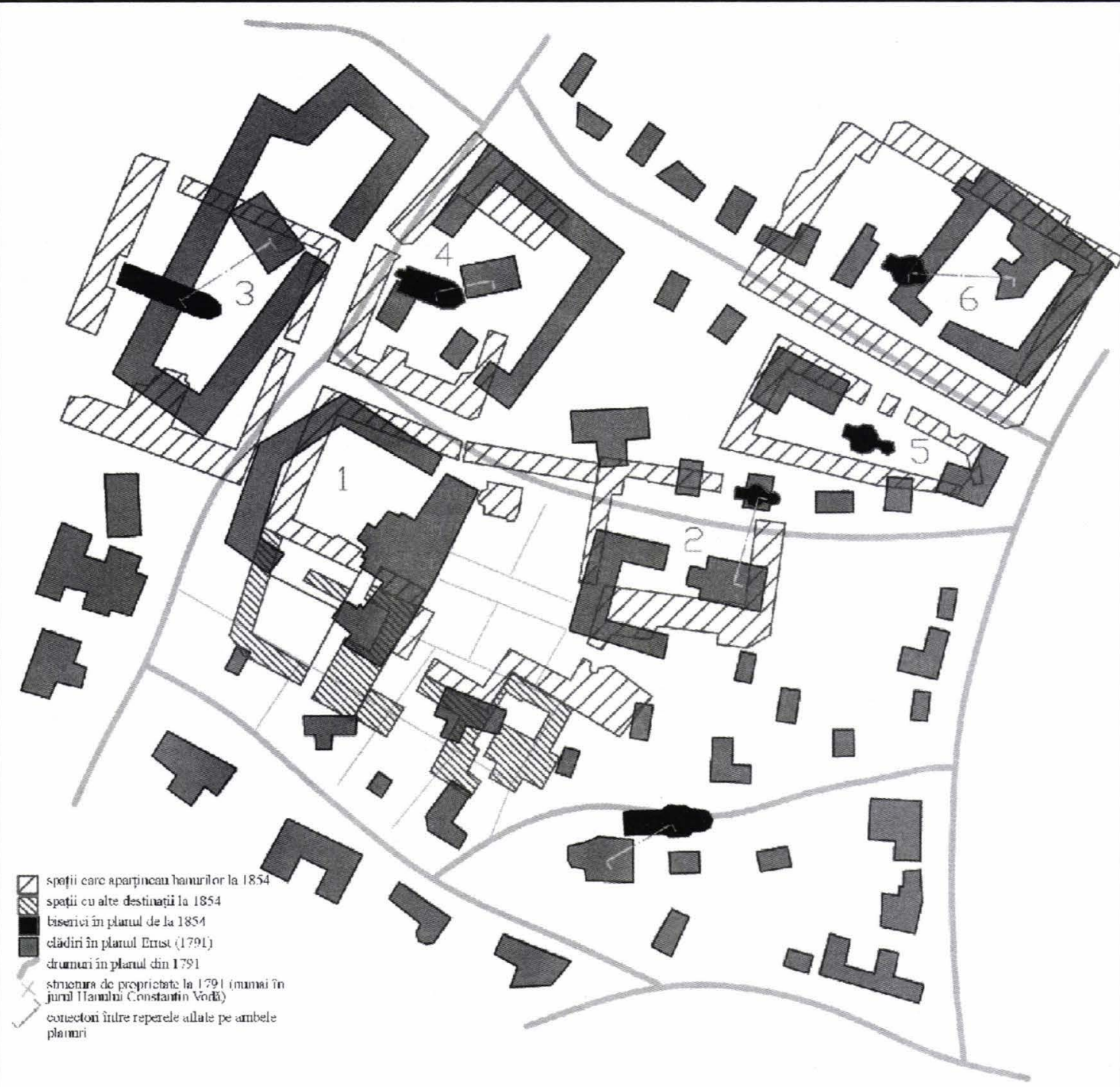

PLANȘA III/3. Supapunere între planurile Bucureștiului de la 1854 (Borroczyn - detaliu din zona Hanului Constantin Vodă) - hașuri diverse, şi planul de la 1791 datorat ofițerului austriac Ernst diverse nuante de gris.

Sunt marcate următoarele puncte: 1. Hanul Constantin Vodă; 2. Hanul Stavropoleos; 3. Hanul Sf. Ioan cel Mare; 4. Hanul Zlătari; 5. Hanul Greci; 6. Hanul Șerban Vodă; fără număr - Biserica Sf. Dumitru.
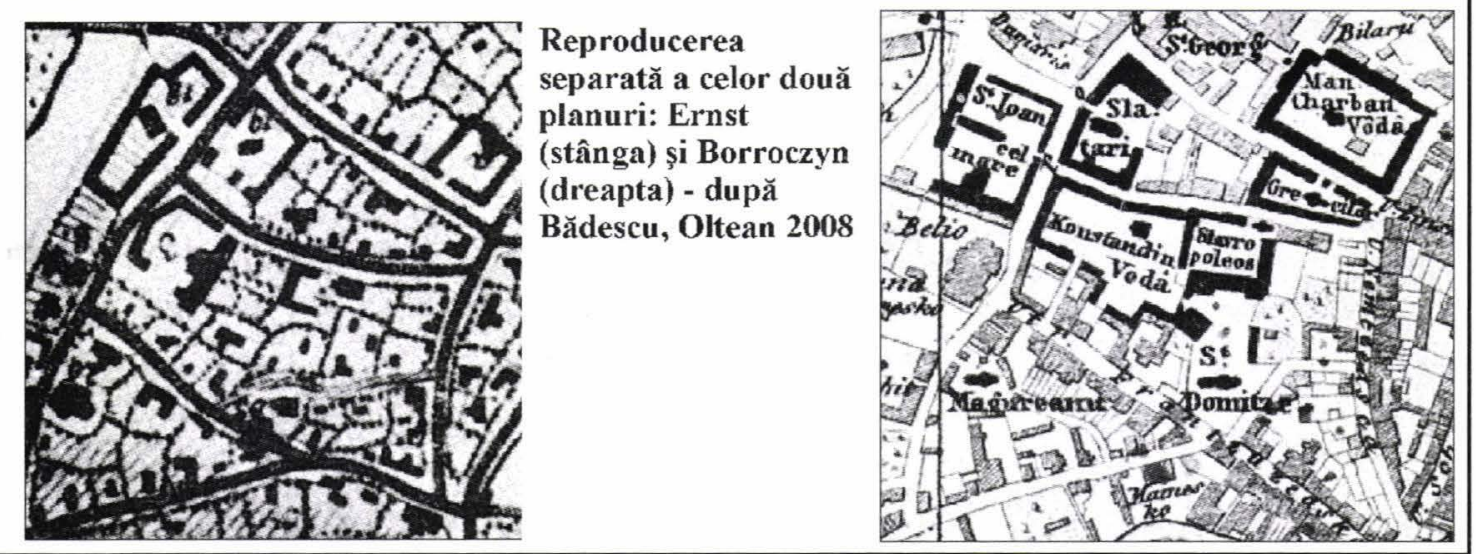


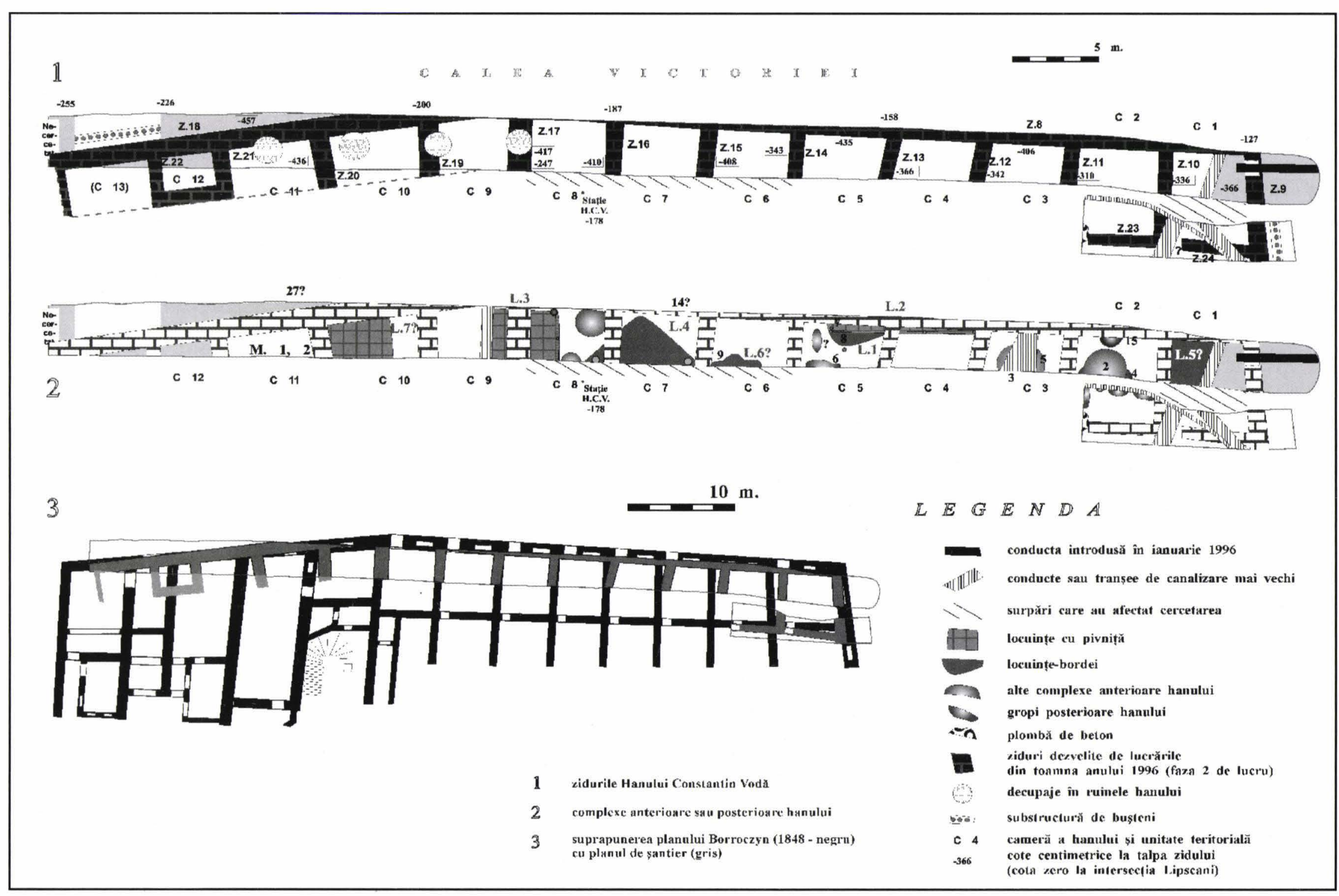

Pl. IV — Săpăturile de salvare de la Hanul Constantin Vodă, din 1996 
1. Fragment din profilul de est al Camerei

5. Deşi această fotografie alb-negru, pregătită pentru publicare, este departe de a

fi de ajutor în analiza stratigrafice, ea este totuşi relativ paradigmatică pentru alternanța tipică a straturilor arheologice, rezultată din

nivelările succesive cu argilă de diverse consistențe (notate A), amenajările podelelor (notate B, de lemn, cu excepția, probabil, a celei superioare), reconstructiile (refacerile) marcate de straturi de mortar (notate C) şi straturi de moloz, obișnuit prezente sub amenajarea modernă a străzii (D).

Partea inferioarã a fotografiei, nemarcată, reprezintă depuneri antropice anterioare construcției Hanului Constantin Vodă.

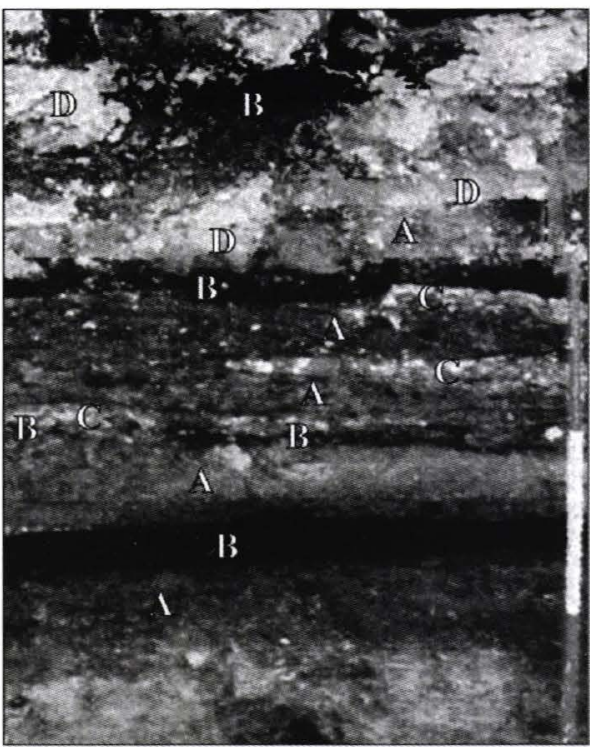

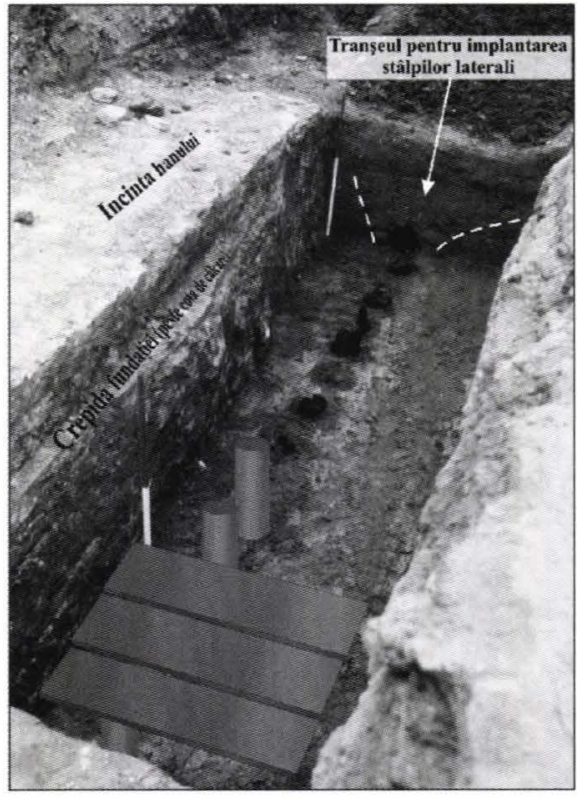

2. Extremitatea sudică a cercetării, pe exteriorul zidului de incintă; în centru - şirul de stâlpi din infrastructura Podului Mogoşoaiei, într-o etapă de lucru (vedere spre sud). În partea inferioară a imaginii se sugerează cota inițială a buștenilor vertical și tăblierul de scânduri a "podului".

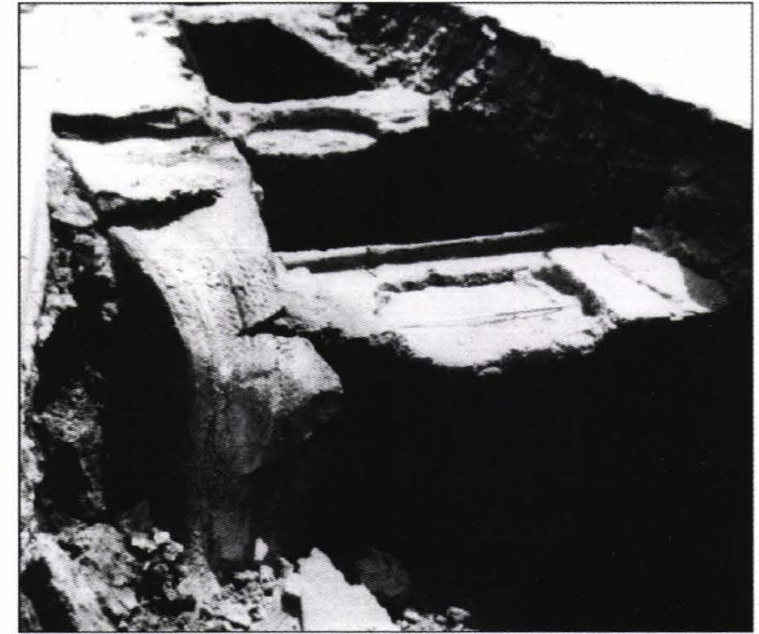

3. Malul de est al secțiunii prăbușit în dreptul Camerei 8; în planul al doilea - decupajele rotunde în Z. 17 şi Z. 19 (vedere spre sud).

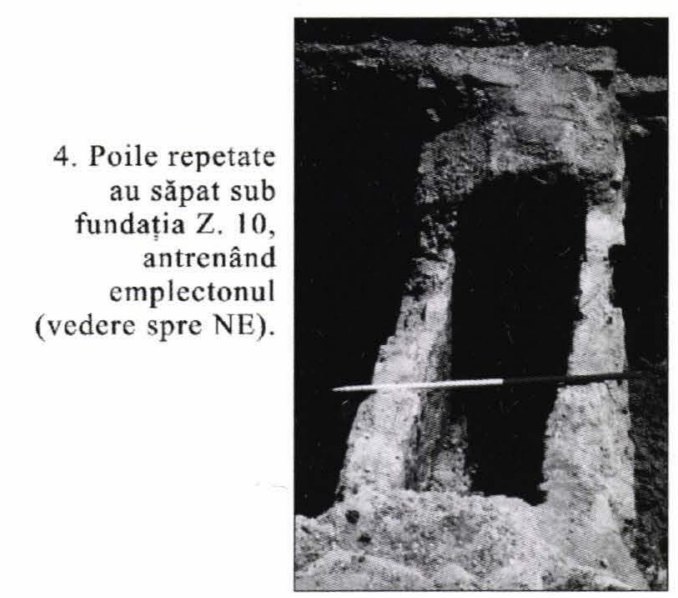

PI. V — Fotografii de la Hanul Constantin Vodă 


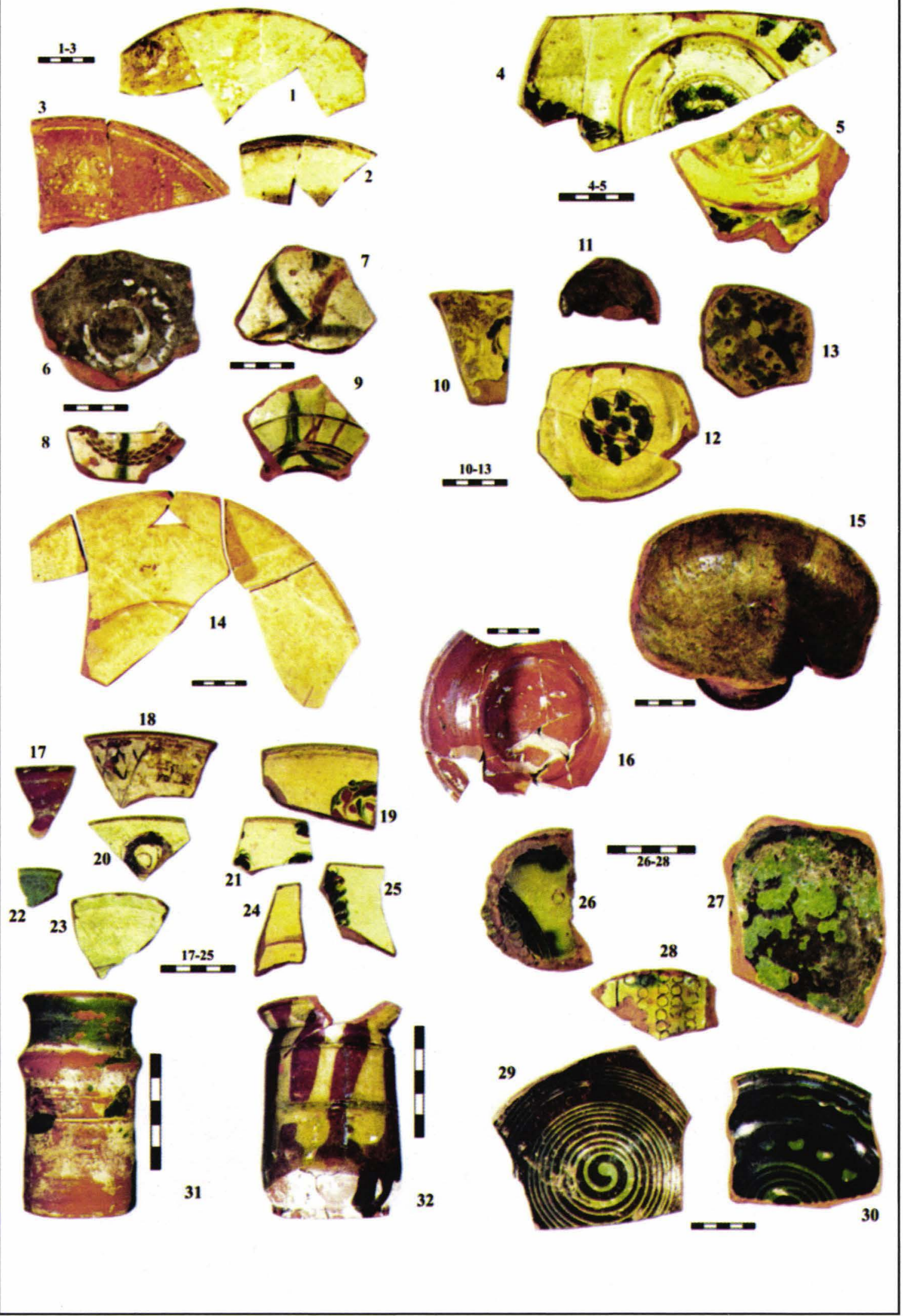

PI. VI - Ceramică de la Hanul Constantin Vodă 


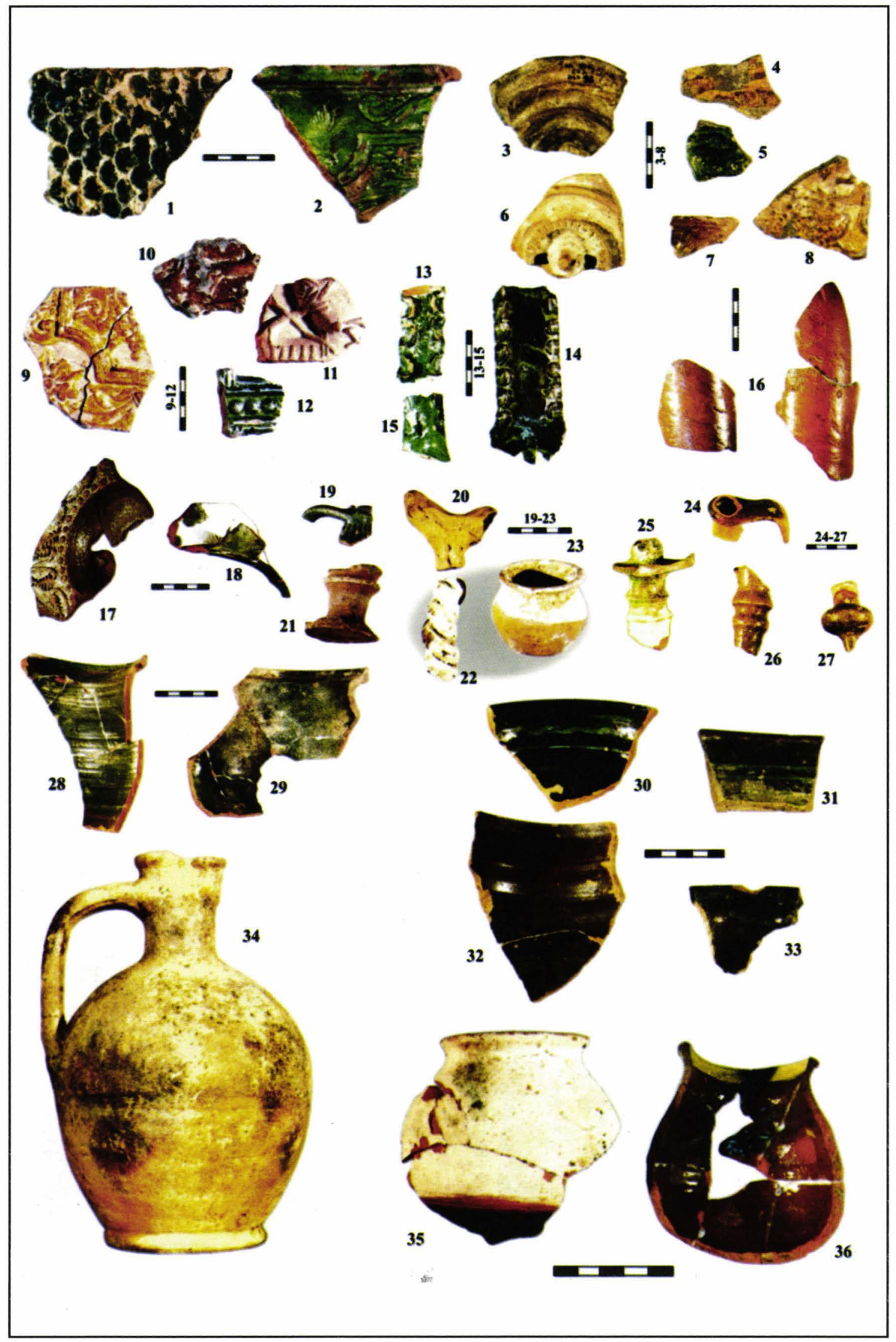

PI. VII - Ceramică de la Hanul Constantin Vodă (2). 

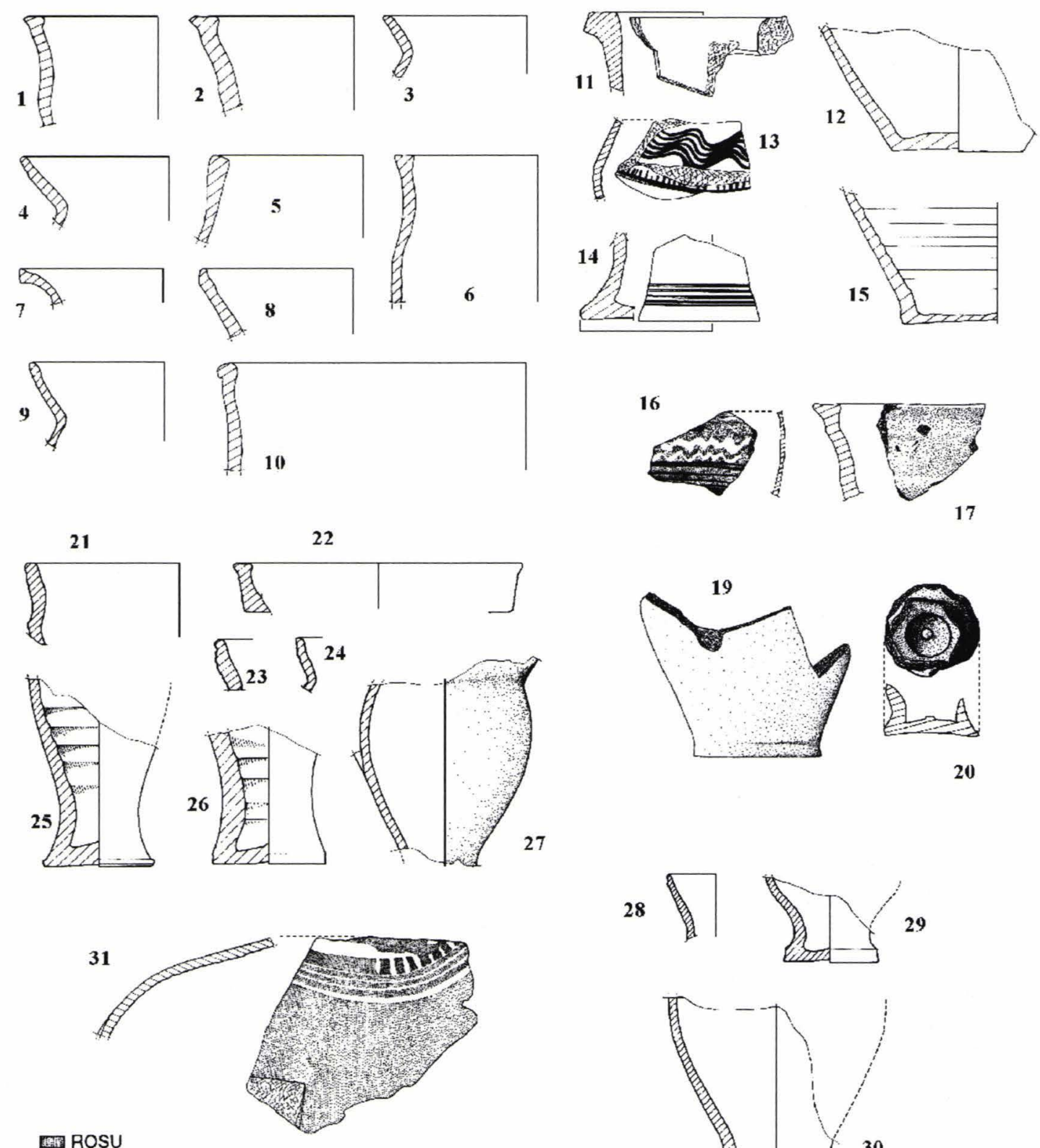

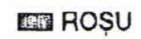

VOPSEA
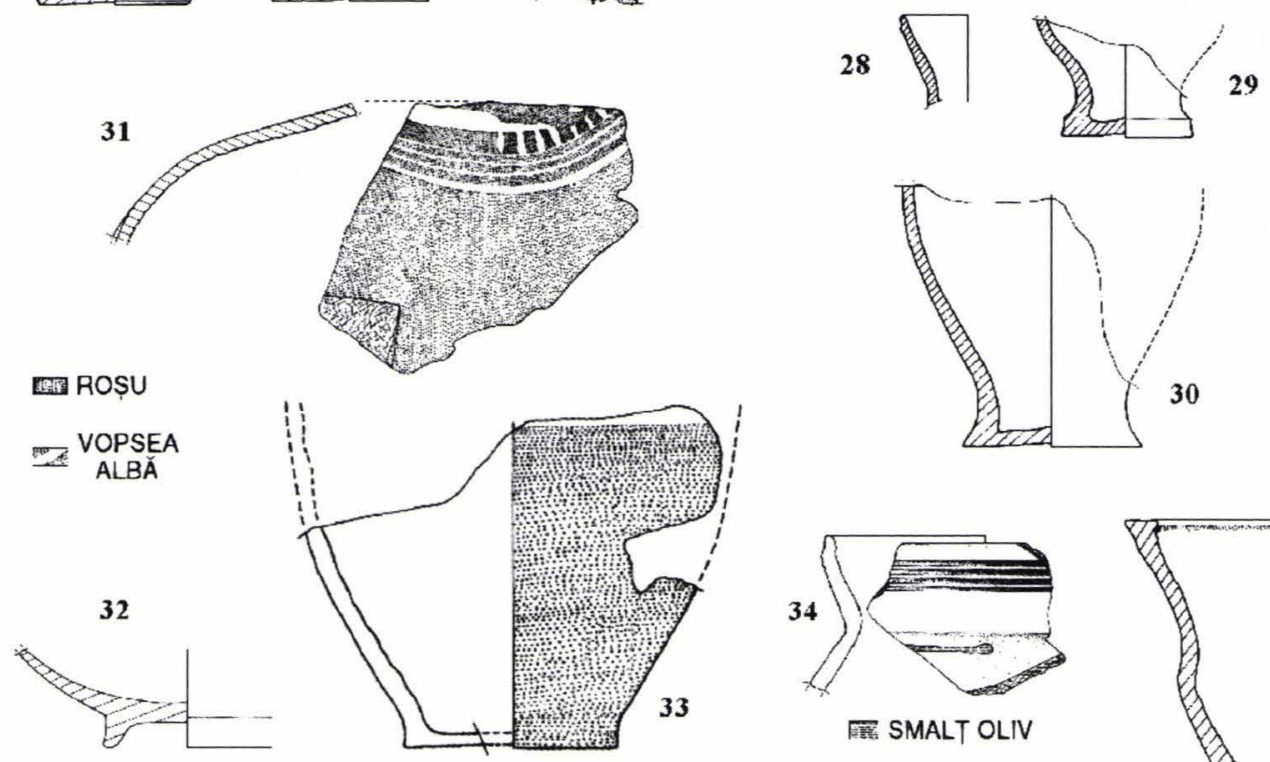

露 SMALT OLIV

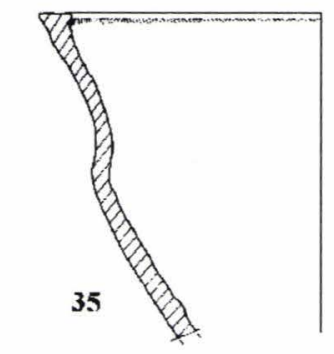

PI. VIII — Ceramică de la Hanul Constantin Vodă 

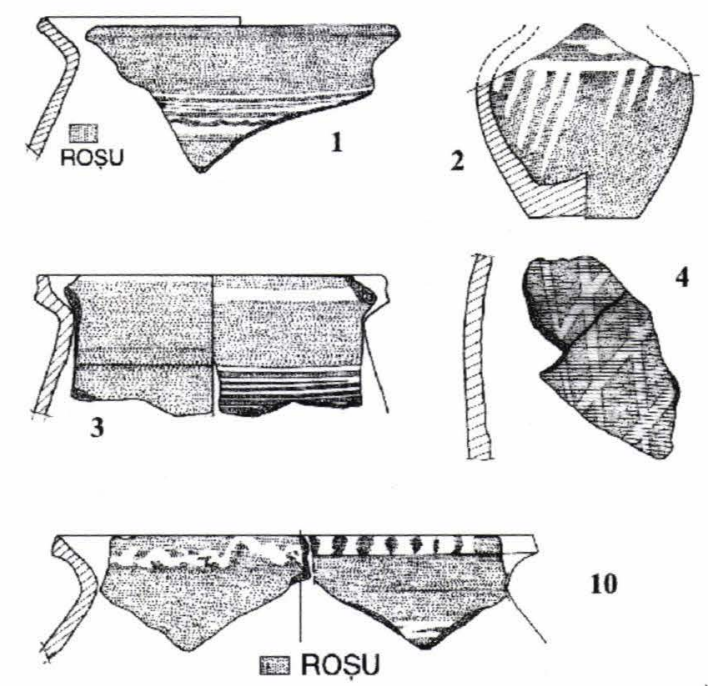

10
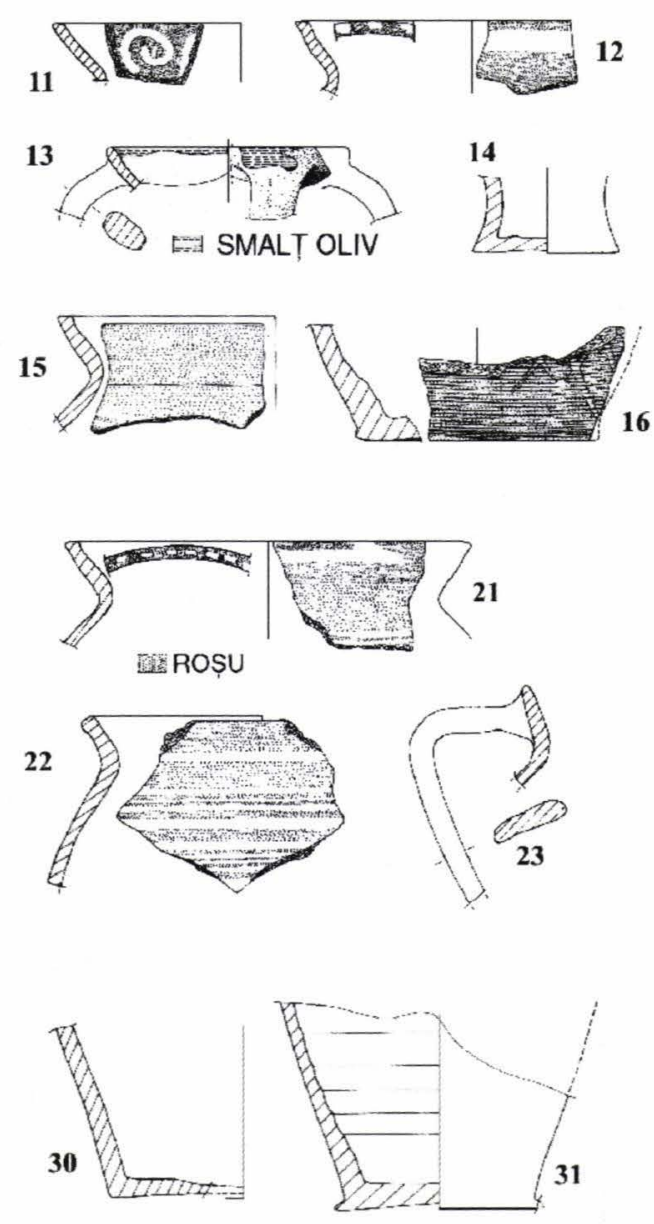

24
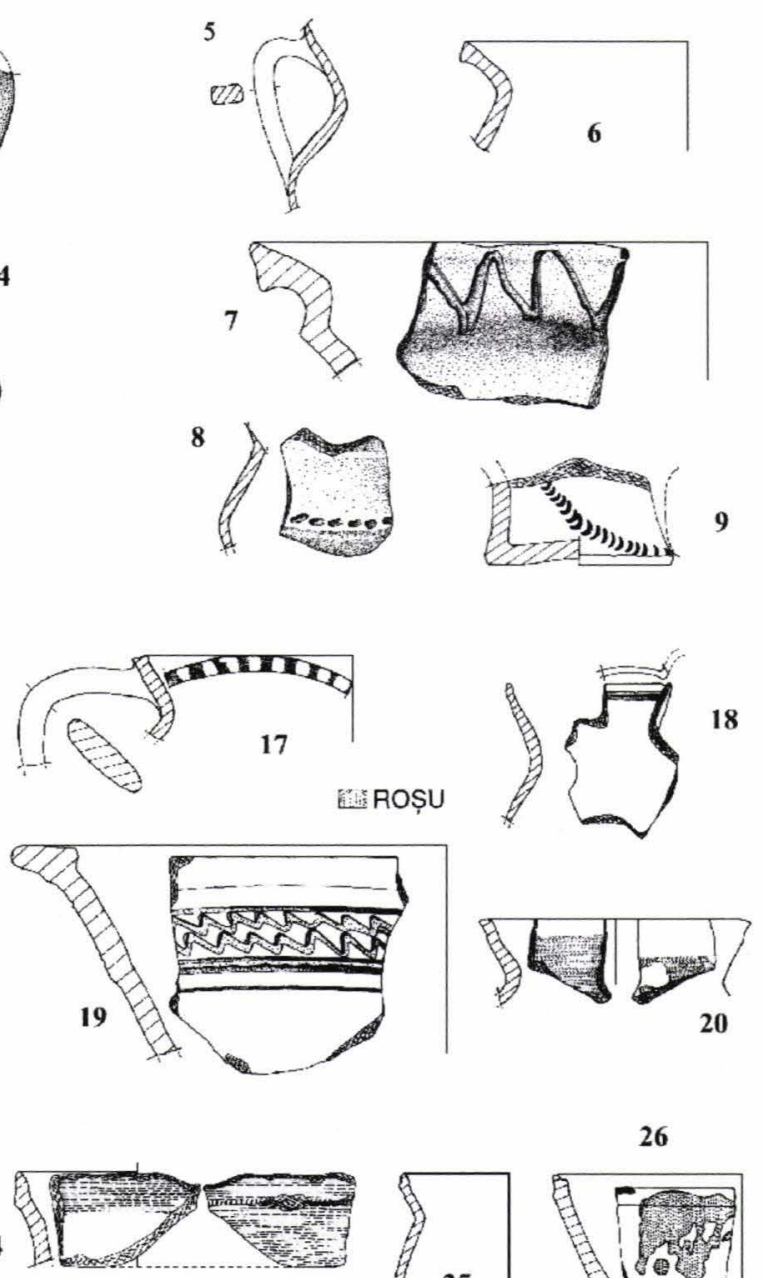

풀 $V E R D E$
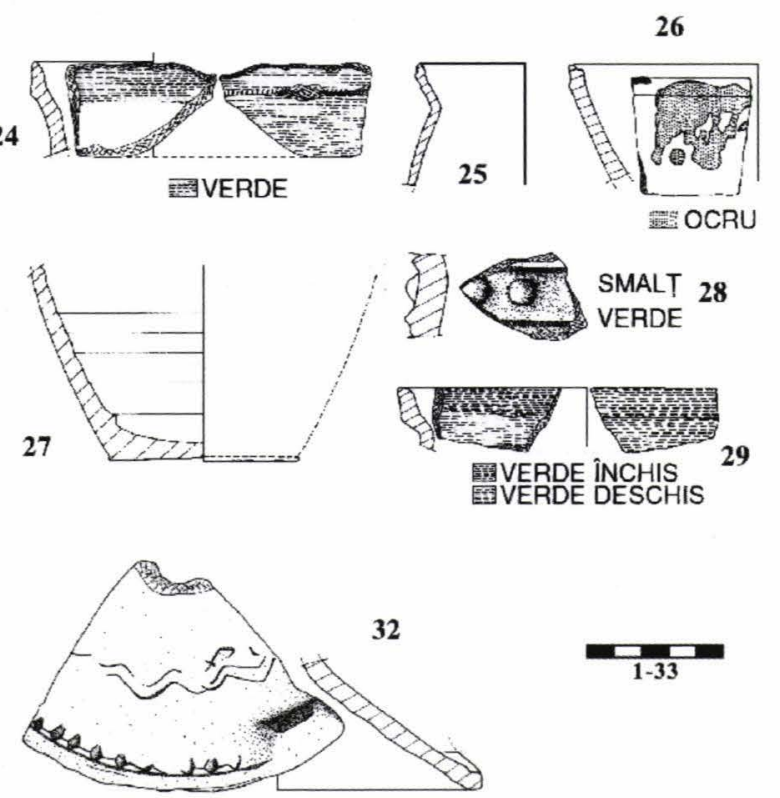

33

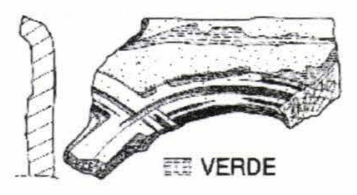

PI. IX - Ceramică de la Hanul Constantin Vodă 

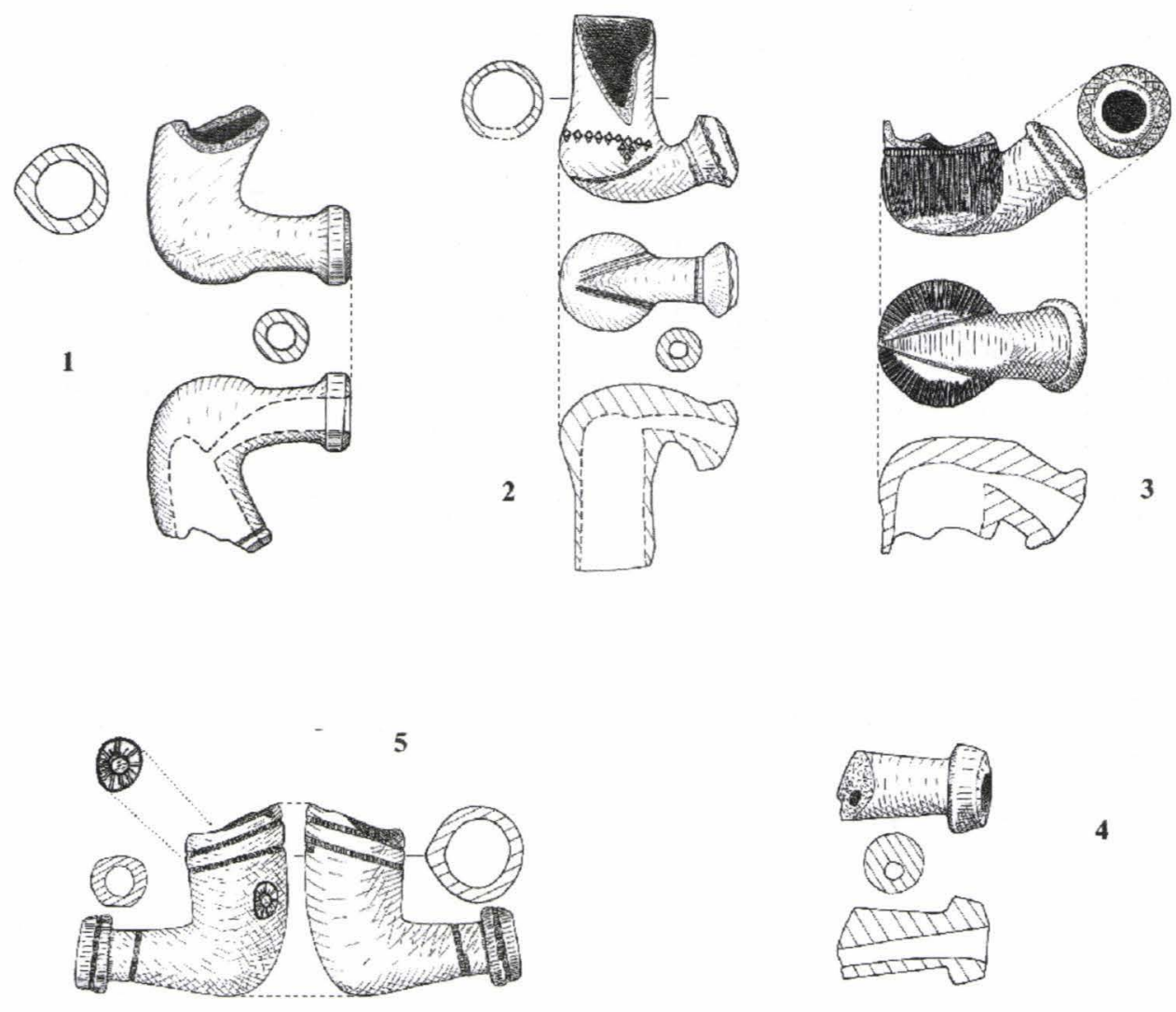

$1-12$
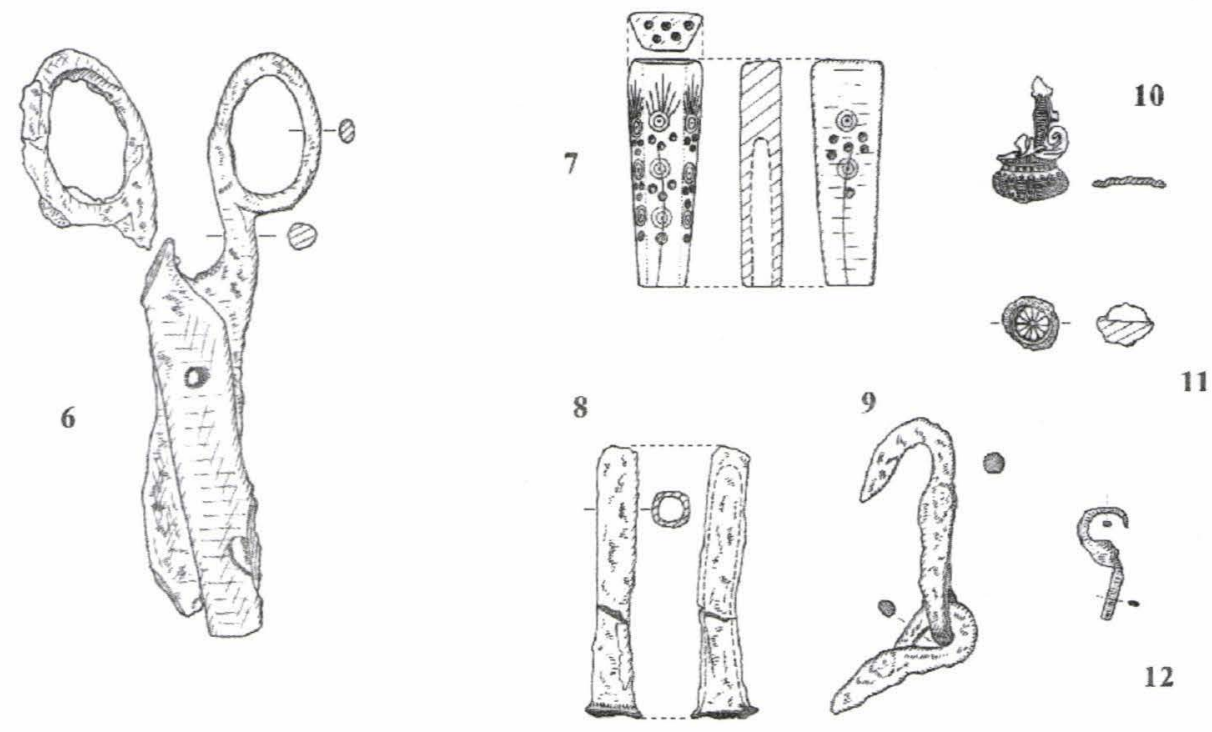

PI. X - Hanul Constantin Vodă - selecție de ,piese mărunte” din inventarul arheologic 
Tabel comparativ cu cote de şantier (cota zero între coloanele centrale ale MNIR) şi graficul ilustrativ

\begin{tabular}{|c|c|c|c|c|c|c|c|}
\hline $\begin{array}{l}\text { ziduri } \\
\text { V-E }\end{array}$ & $\begin{array}{c}\text { talpă } \\
\text { fundaţie }\end{array}$ & $\begin{array}{c}\text { cote } \\
\text { decroş }\end{array}$ & $\begin{array}{c}\text { cote } \\
\text { asfalt* }\end{array}$ & $\begin{array}{l}\text { cote zid N-S la } \\
\text { corespondenţă }\end{array}$ & $\begin{array}{l}\text { nivel de fundare } \\
\text { (prima podea) }\end{array}$ & $\begin{array}{c}. .1 \mathrm{la} \\
\text { camera... }\end{array}$ & cota steril \\
\hline 10 & -336 & -199 & -150 & -383 & -280 & C. 1 & -340 \\
\hline $11-3 \mid$ & $0-214-155$ & -399 & & 275 & 335 & & \\
\hline 12 & -335 & & -160 & -445 & -300 & (?)C.3 & -335 \\
\hline 13 & -366 & & -166 & -436 & -296 & C. 4 & -351 \\
\hline $14-3 \$$ & $-17 \beta$ & -453 & & 303 & $\beta 53$ & & \\
\hline 15 & -410 & & -179 & & & C.6 & \\
\hline 16 & & & -187 & & -342 & C.7 & -367 \\
\hline 17 & -423 & -260 & -195 & & -315 & C.8 & -370 \\
\hline 19 & & & -203 & -410 & -363 & C.9 & -410 \\
\hline 20 & -436 & -263 & -217 & & -363 & C. 10 & -427 \\
\hline 21 & 60 & -276 & -239 & -457 & -399 & C.11 & -449 \\
\hline
\end{tabular}

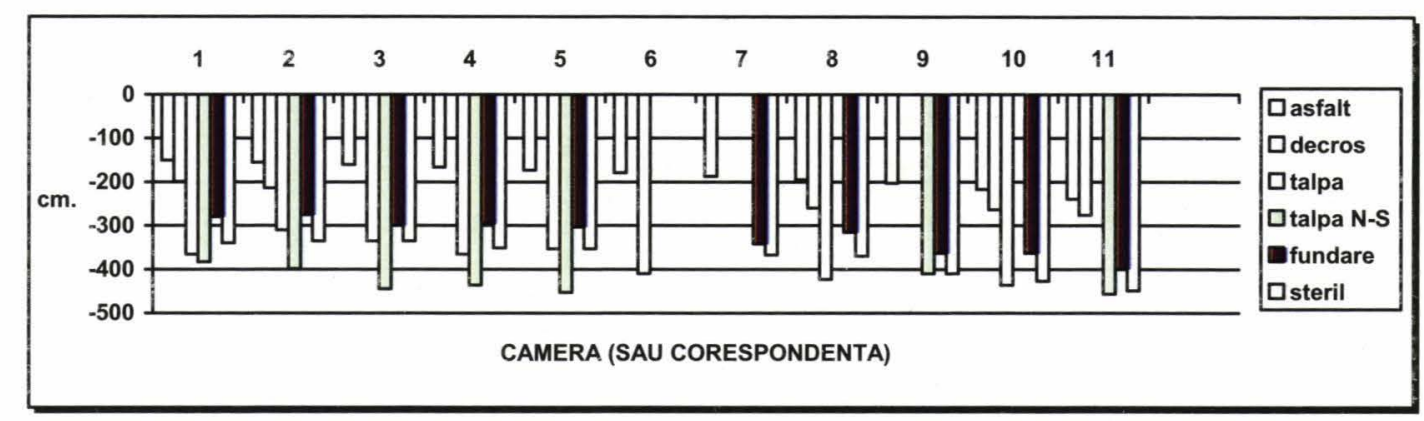

* Cotele la asfalt au fost luate, pentru această statistică, pentru malul de E (pe Calea Victoriei, lângă bordură), cote care există numai pe planul de lucru; pe planșa corespondentă (Pl. IV) aceluiaşi desen figurează numai cotele de pe malul de V, pentru a nu aglomera imaginea; aceste cote, de V, sunt în general cu 5-6 cm mai sus, aflându-se spre mijlocul căii de rulare; „talpa N-S” din grafic arată cotele inferioare ale Z.8, orientat nord-sud; tot acolo, ,asfalt” arată cota căii de rulare în dreptul fiecărui zid.

Pl. XI -1 
Tabel pentru reprezentarea sinoptică a nivelurilor de amenajare a podelelor în camere Hanului $(\mathrm{C}=$ cameră $)$.

\begin{tabular}{|c|c|c|c|c|c|c|c|c|c|}
\hline $\begin{array}{l}\text { Camere } \\
\text { Adâncimi } \\
(\mathrm{cm})\end{array}$ & $\mathrm{C} 1$ & $\mathrm{C} 2$ & $\mathrm{C} 4$ & C5 & C7 & C8 & C9 & $\mathrm{C} 10$ & C11 \\
\hline-25 & \multirow{14}{*}{ 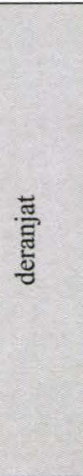 } & cărăm & \multirow{7}{*}{ 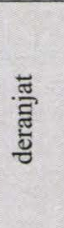 } & \multirow{8}{*}{ 莺 } & \multirow{4}{*}{ 嗬 } & & \multirow{11}{*}{ 营 } & \multirow{4}{*}{ 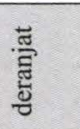 } & \multirow{4}{*}{. } \\
\hline-30 & & & & & & $\approx$ & & & \\
\hline-35 & & & & & & & & & \\
\hline-40 & & cărăm & & & & ? & & & \\
\hline-45 & & & & & cărăm & cărăm & & \multirow{10}{*}{ 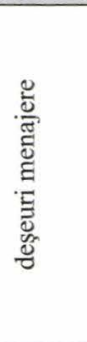 } & \multirow{10}{*}{ 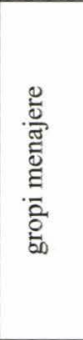 } \\
\hline-50 & & cărăm & & & & & & & \\
\hline-55 & & & & & & & & & \\
\hline-60 & & & & & & & & & \\
\hline-65 & & & lemn & & & & & & \\
\hline-70 & & & & cărăm & & & & & \\
\hline-75 & & & & & & & & & \\
\hline-80 & & & & & & lemn & & & \\
\hline-85 & & & lemn & & & & & & \\
\hline-90 & & cărăm & & & & cărăm & & & \\
\hline-95 & & & & lemn & lemn & & & & \\
\hline-100 & cărăm & & & & & & cărăm & cărăm & cărăm \\
\hline-105 & lemn & & lemn & & & & & & \\
\hline-110 & & lemn & & & & & & & \\
\hline-115 & & cărăm & & cărăm & cărăm & & & & \\
\hline-120 & & lemn & lemn & & & cărăm & & & \\
\hline-125 & & & & cărăm & cărăm & & & & ? \\
\hline-130 & lemn & & lemn & lemn & & & & cărăm & \\
\hline-135 & & & & & & & & & \\
\hline-140 & & & & & & & lemn & & ? \\
\hline-145 & & & & & & & & cărăm & \\
\hline-150 & & & & & lemn & & & & \\
\hline-155 & & , & & & lemn & & & & ? \\
\hline
\end{tabular}

legenda:

\begin{tabular}{|c|l|}
\hline lemn & podele construite din lemn, pe pat de argilă \\
\hline cărăm & podele construite din cărămidă (şi alte materiale dure de construcție) \\
\hline cărăm & podele din care a rămas strict stratul inferior, de argilă; probabil iniţial cărămidă \\
\hline$?$ & nivelări cu lut, cu scop greu precizabil \\
\hline & $\begin{array}{l}\text { niveluri care au suferit scufundări semnificative, ca urmare a unor tasări } \\
\text { puternice, cota lor fiind strict orientativă }\end{array}$ \\
\hline lemnn
\end{tabular}

Notă: nivelurile sunt cotate aici de la asfalt; pentru corelația lor pe altimetria generală vezi Planşa XI/1. 


\section{asfalt}

pământ negru (depunere) în amestec

cu lut şi pigment cărbune

pământ negru cu mult cărbune şi chirpic ars (distrugere? ocupațional?)

pământ negru, clisos, cu cărbune (lemn ars)

pământ negru, clisos, cu cărbune și cenușã

pământ negru-verzui (inundație?)

pământ negru-brun cu pigment de cărbune

pământ brun cu chirpic mărunt şi urme de arsură (consistență mare - amenajare)

pământ (lemn putrezit?) brun-roşcat

lut depus

lut depus, în amestec cu pământ şi pigment cărbune (amenajare)

lut galben-roșcat, neomogen, cu pământ negru-vinețiu si pigment cărbune

lut compact, galben (formațiune naturală)

podea tare, verzui-roșiaticã

pământ negru-brun cu pigment de cărbune şi cărămizi fragmentare

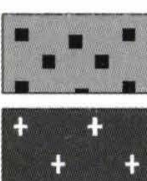

strat nisipos, albăstrui

pământ ars in situ (la roșu)

mortar

cenușă

strat arsură

chirpic ars

moloz (cărămidă spartă, mortar, etc.)

podea cărămidă

suportul de lut al unei podele de cărămidă (aceasta prost sau deloc conservatã)

lemn putrezit (podea)

bârnă (negativ)

PI. XII - Legenda desenelor de profil stratigrafic (vezi planșele XIII și XIV) 


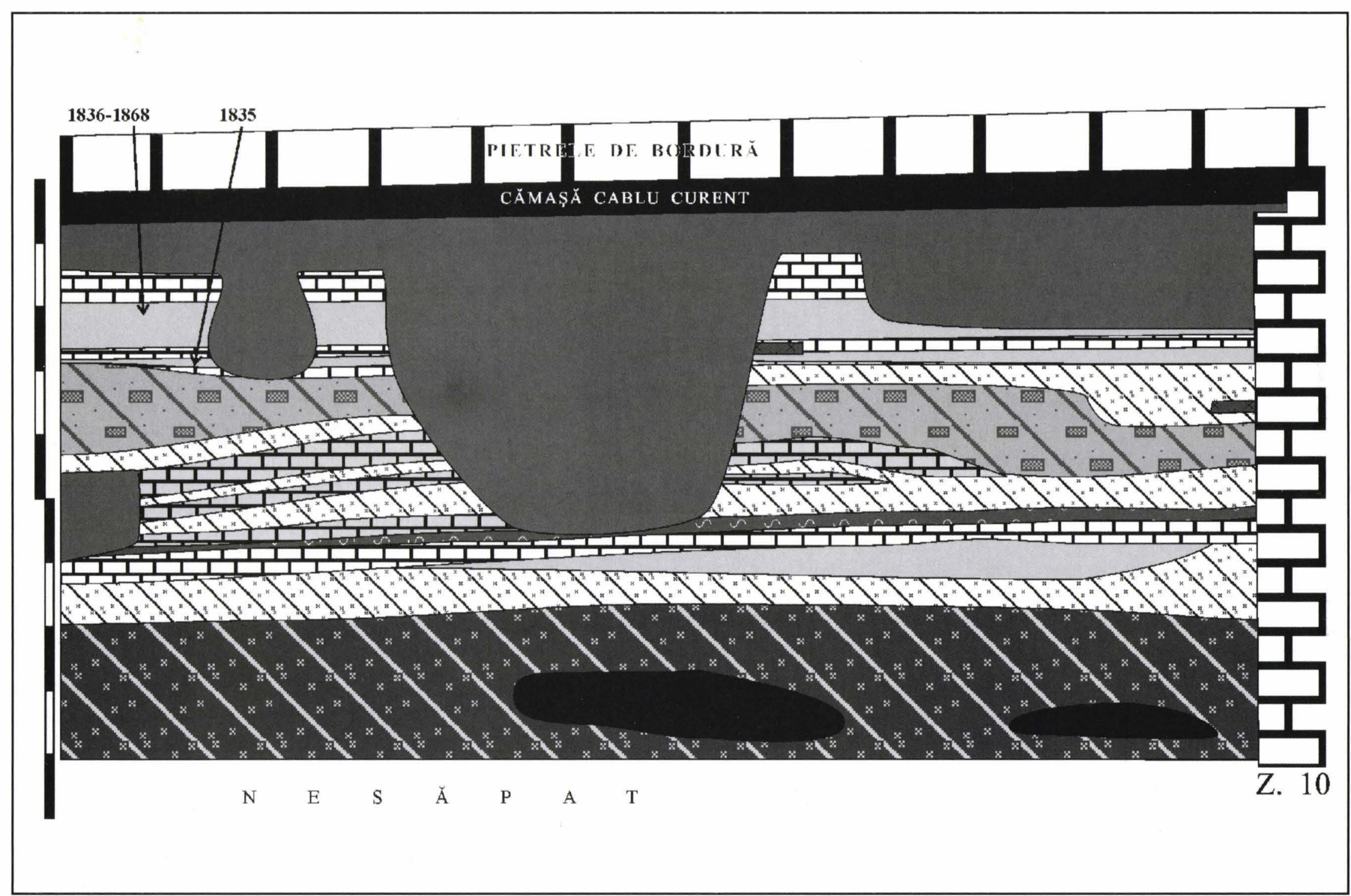

PI. XIII - Hanul Constantin Vodă. Caseta, profil vestic, în dreptul Camerei 2. Este indicat poziția stratigrafică a elementelor certe de datare (vezi „Lista monedelor”). Pentru semnificația hașurilor - vezi pl. XII. 


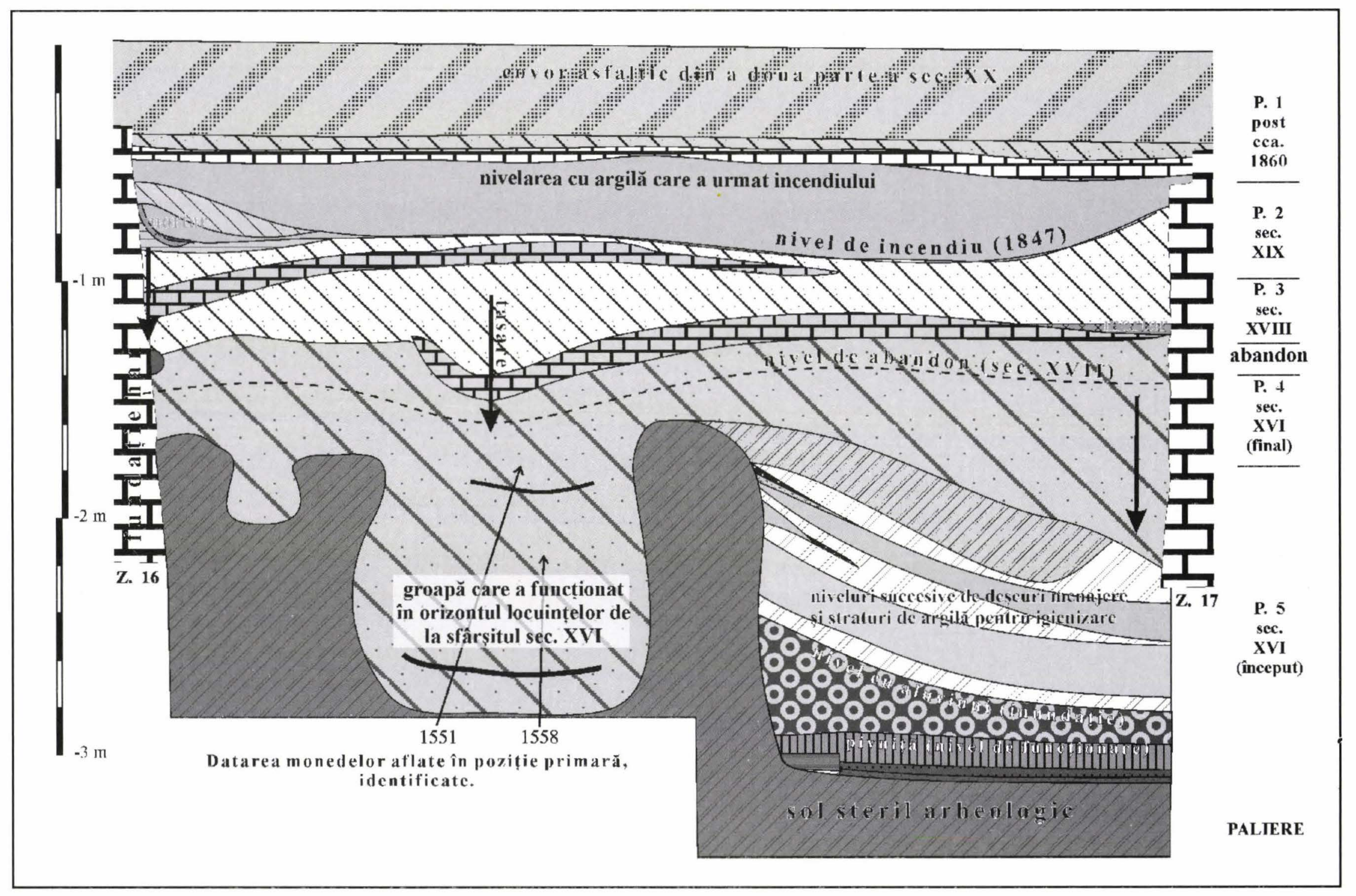

PI. XIV - Camera 8. Profilul de est 


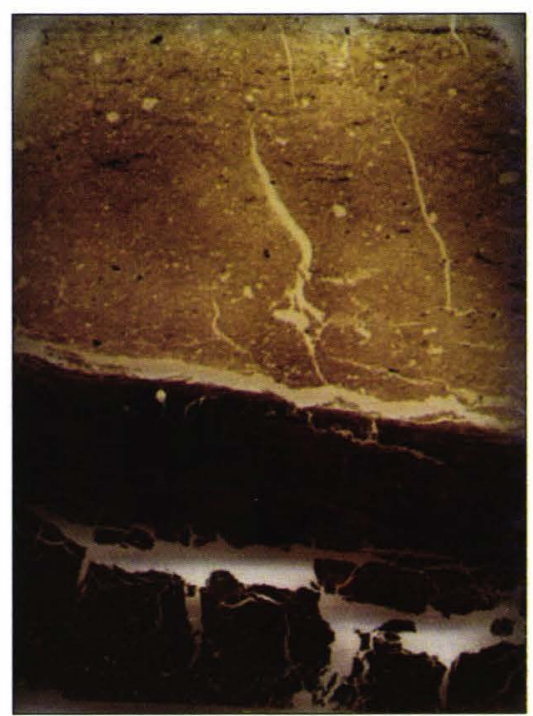

1. Imagine scanată a secţiunii S 1 .

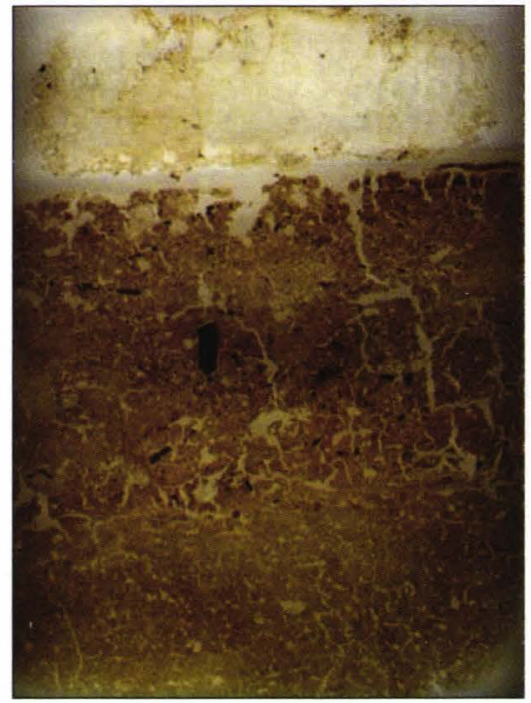

3. Imagine scanată a secţiunii S 11 .

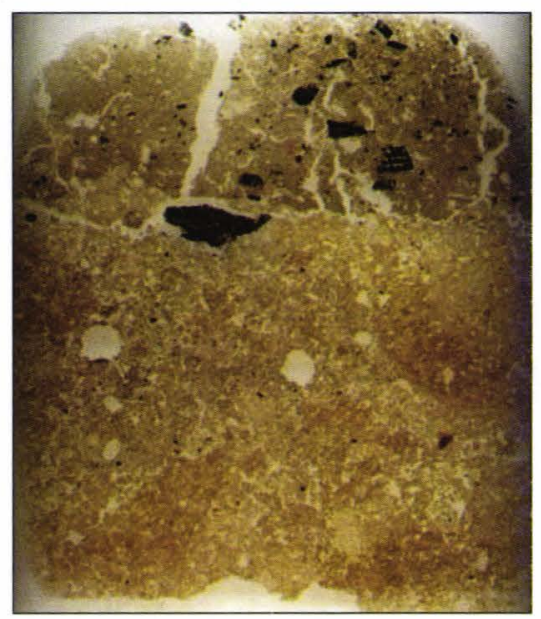

2. Imagine scanată a secţiunii S 7 .

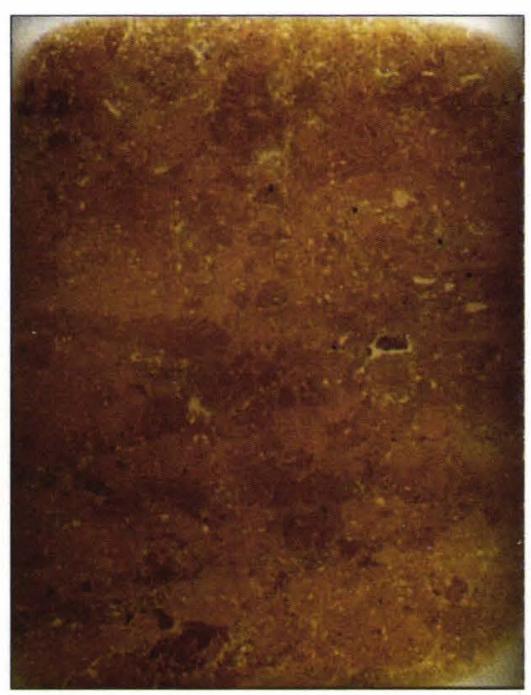

4. Imagine scanată a secţiunii S 18.

PI. XV — Imagini scanate ale unor secțiuni micromorfologice. Lățime de imagine $6 \mathrm{~cm}$ 


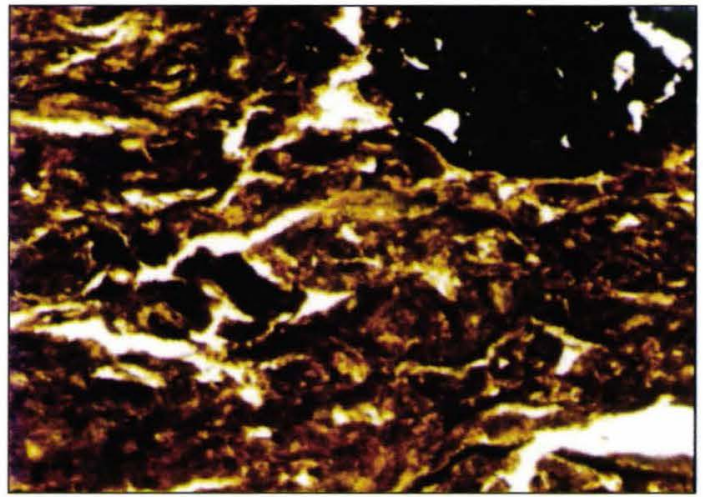

1. S 1 - US 117. Nivel ocupaţional, compactat, cu fragmente de cărbune. PPL, 1. i. 2 mm.

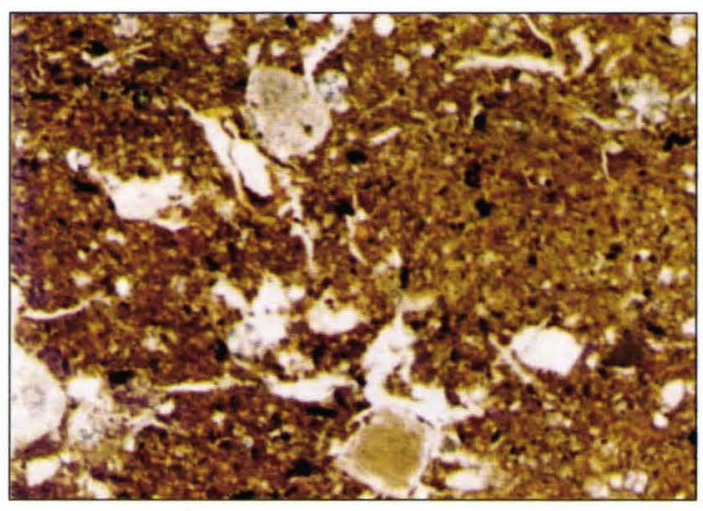

3. S 1 - US 115. Podea de lut. PPL, 1. i. $2 \mathrm{~mm}$

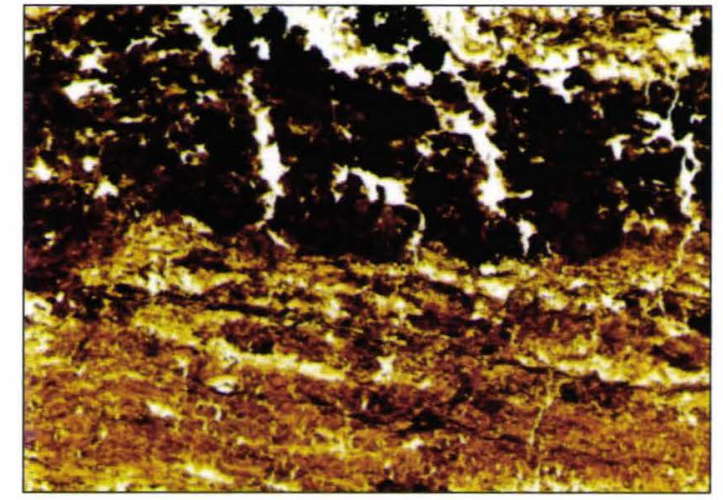

2. S 1 - US 116. Podea de lemn ce conservă structura vegetală. PPL, 1. i. $2 \mathrm{~mm}$.

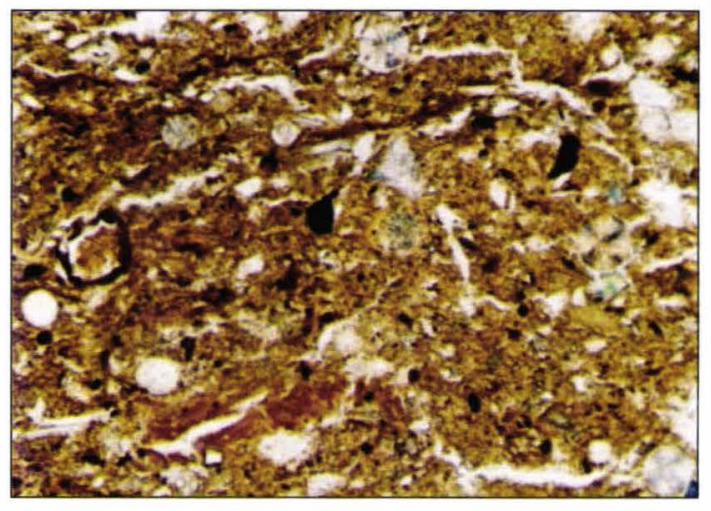

4. S 1 - US 115. Acumulare organic ă, cu fragmente vegetale. PPL, 1. i. $1 \mathrm{~mm}$.

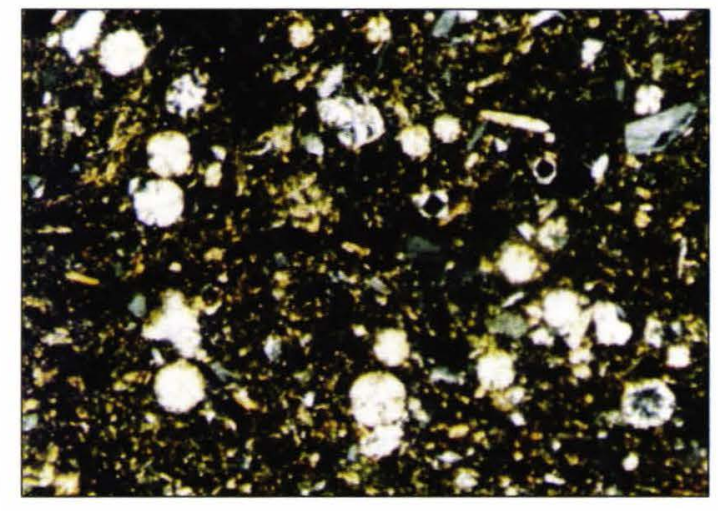

5. S 1 - US 115. Acumulare organic ă, cu abundente sferolite. XPL, 1. i. $1 \mathrm{~mm}$.

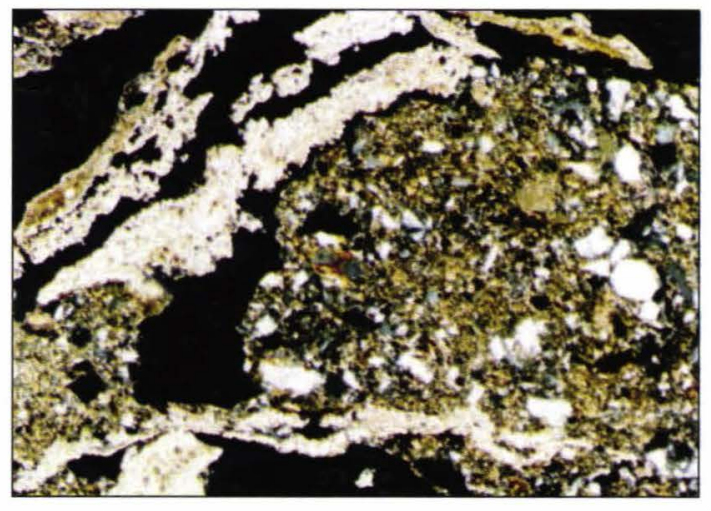

6. S 5 - US 113. Acumulare calcitică fin cristalizată. XPL, l. i. $2 \mathrm{~mm}$.

PI. XVI - Fotografii la microscop ale diferitelor unități sedimentare studiate.

XPL - lumină polarizată încrucișată; PPL - lumină polarizată plan; 1.i. - lățime imagine. 


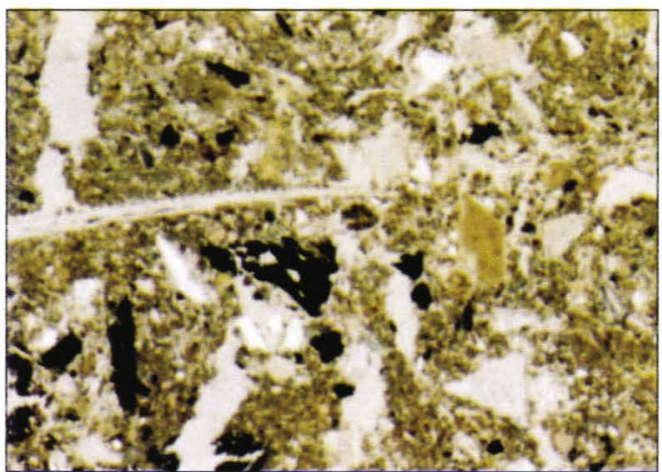

1. S 5 - US 108. Nivel de locuire organic, cu cărbune și oase de peşti. PPL, 1. i. $2 \mathrm{~mm}$.

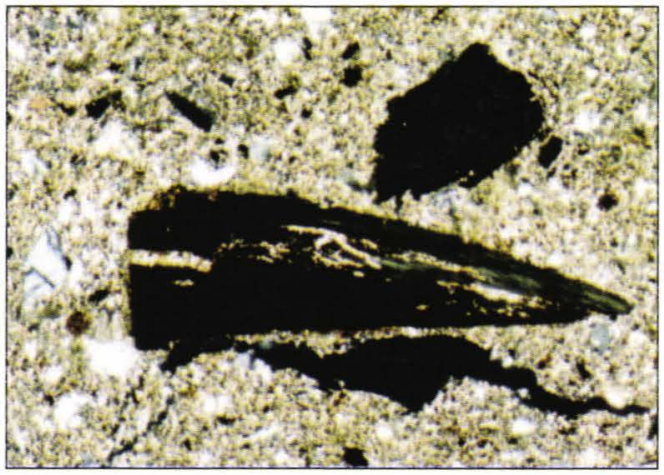

3. S 7 - US 417. Nivel de locuire cu abundentă cenuşă, fragment de os şi cărbune. XPL, 1. i. 2 mm.

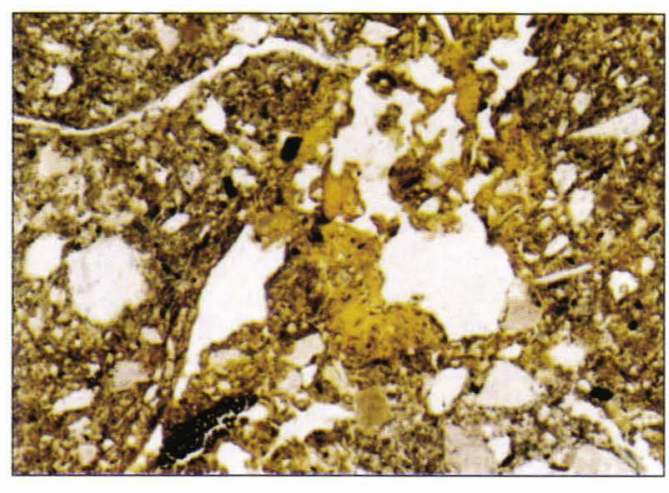

2. S 7 - US 418. Acumulare fosfatică, în goluri. PPL, 1. i. $2 \mathrm{~mm}$.

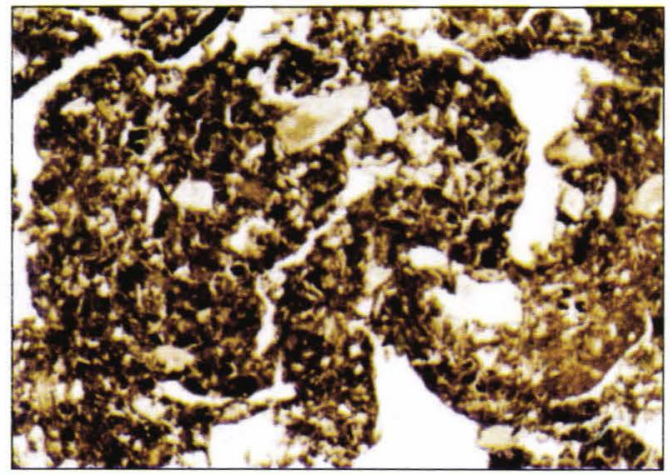

4. S 9 - US 422. Structură de bioturbaţie de către faună. PPL, 1. i. $2 \mathrm{~mm}$.

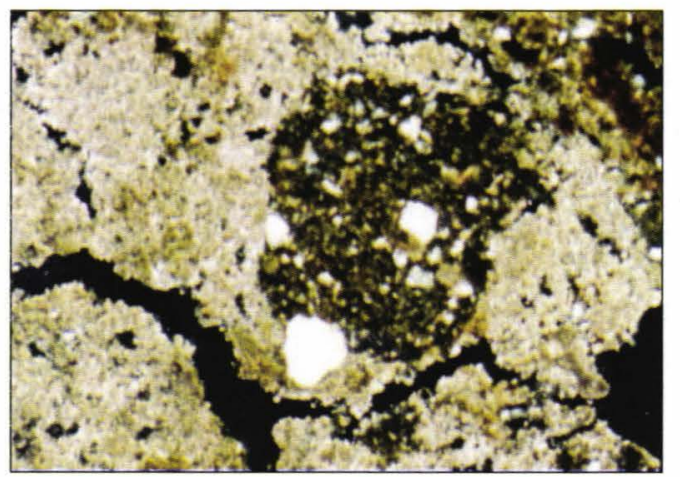

5. S 9 - US 421. Acumulare de cenuşă cu materiale preparate arse. XPL, 1. i. $2 \mathrm{~mm}$.

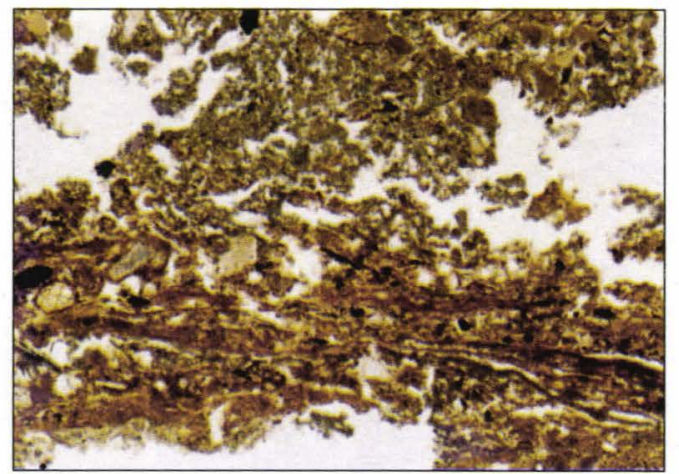

6. S 9 - US 414 Cuvertură vegetală descompusă in situ. PPL, 1. i. $2 \mathrm{~mm}$.

PI. XVII - Fotografii la microscop ale diferitelor unități sedimentare studiate.

XPL - lumină polarizată încrucișată; PPL - lumină polarizată plan; 1.i. - lățime imagine. 


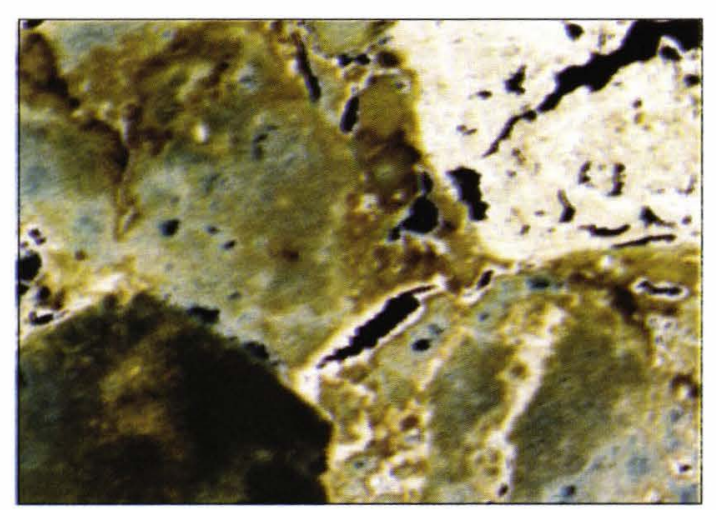

1. S 9 - US 413. Nivel de distrugere cu fragmente de tencuială. XPL, l. i. $2 \mathrm{~mm}$.

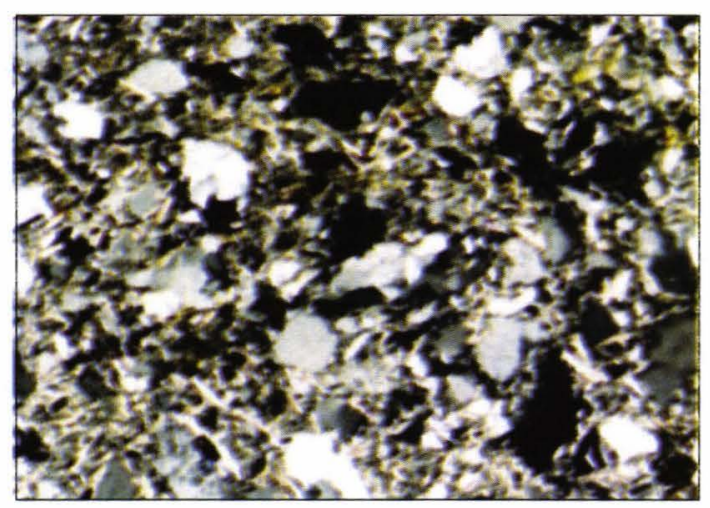

2. S 13 - partea inferioară. Acumulare naturală de nisip fin. XPL, l. i. $2 \mathrm{~mm}$.

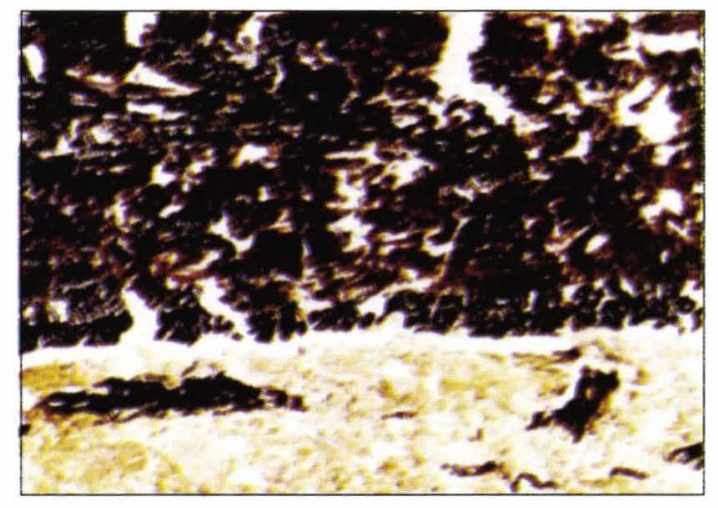

3. S 13. Podea de lemn incendiată in situ. PPL, 1. i. $2 \mathrm{~mm}$.

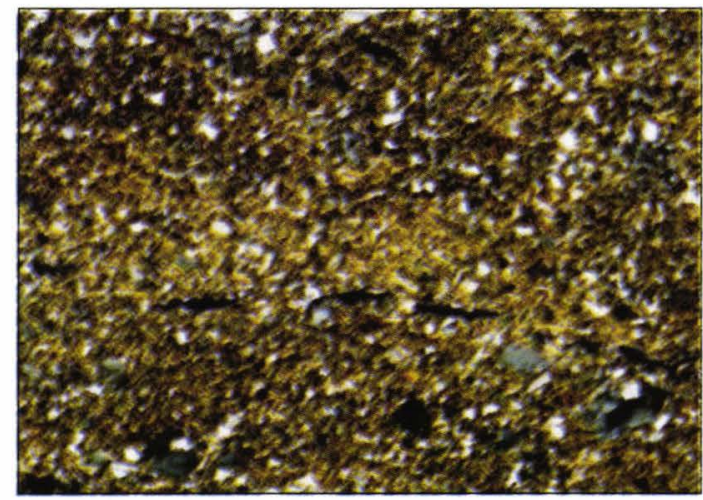

5. S 18. Limită între niveluri argiloase fine. XPL, 1. i. $2 \mathrm{~mm}$.

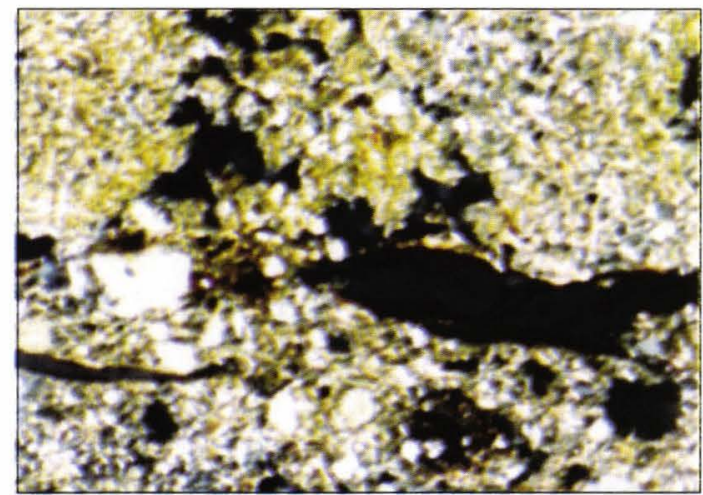

4. S 19. Limită netă între nivelurile descrise. XPL, 1. i. $2 \mathrm{~mm}$.

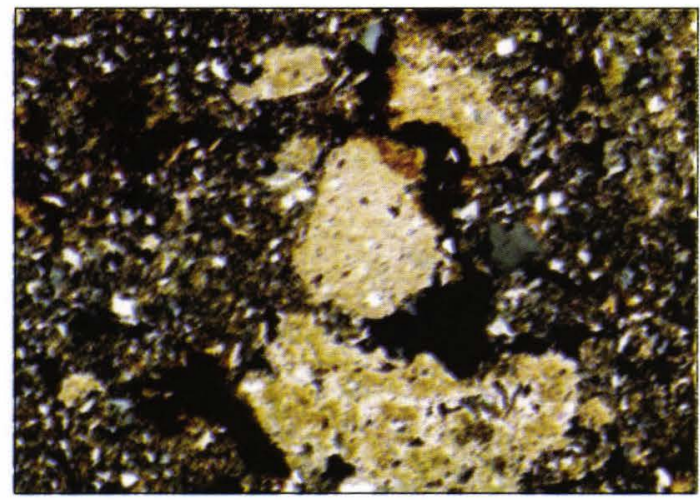

6. S 16 - partea superioară. Acumulare calcitică pe fisuri. XPL, 1. i. $2 \mathrm{~mm}$.

PI. XVIII - Fotografii la microscop ale diferitelor unități sedimentare studiate.

XPL - lumină polarizată încrucișată; PPL - lumină polarizată plan; 1.i. - lățime imagine. 


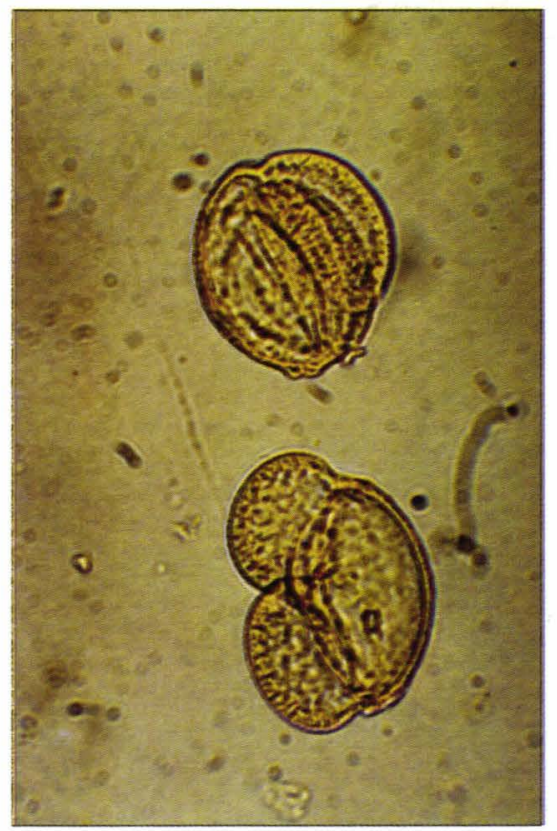

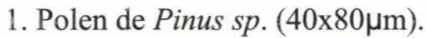

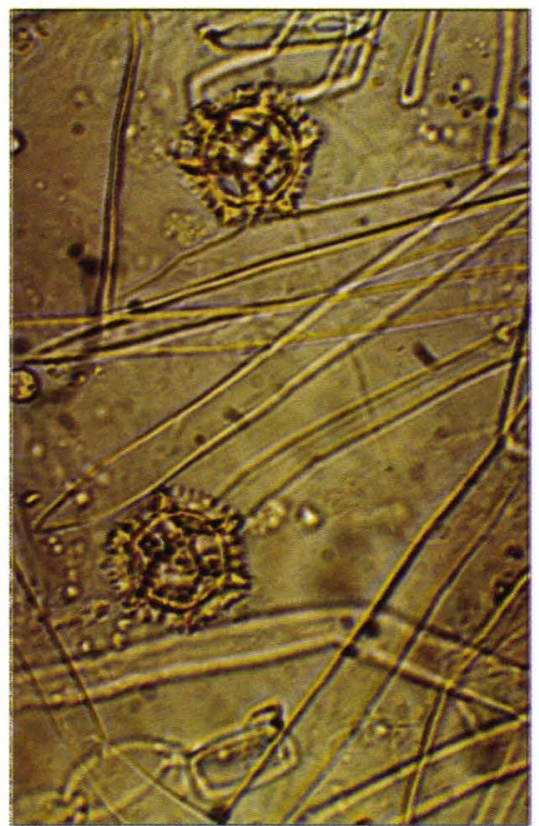

2. Polen de Crepis biennis ( $\varphi 30-40 \mu \mathrm{m})$.

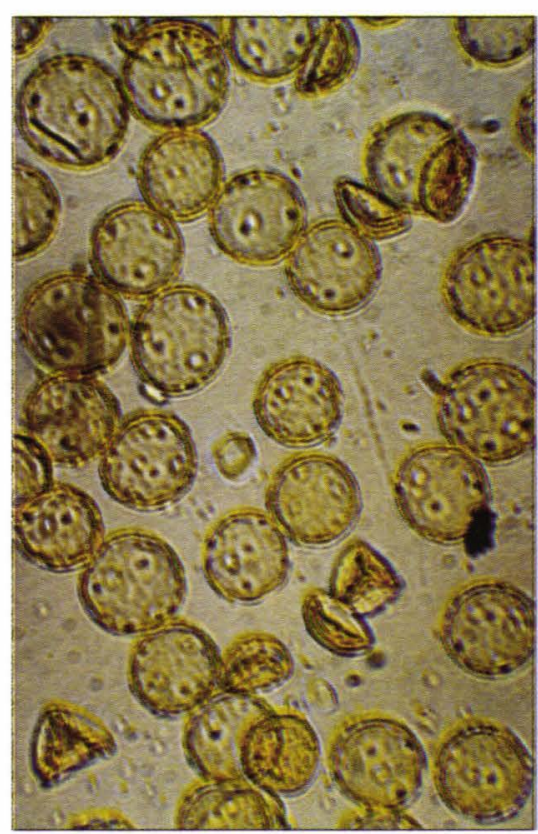

3. Polen de Plantago lanceolata $(\varphi 28 \mu \mathrm{m})$.

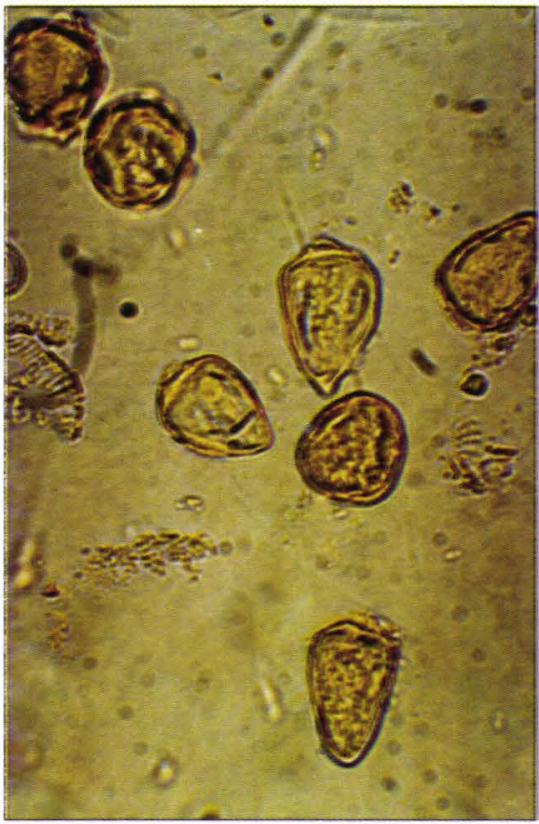

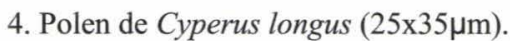

PI. XIX - Fotografii palinologie 
